\title{
BEYOND AID: \\ SUSTAINABLE COMMUNITY-OWNED \\ COOPERATIVE BUSINESS
}

\author{
Margaret Scotts \\ A thesis submitted to \\ Victoria University of Wellington \\ in fulfilment of the requirements for the degree of \\ Master in Development
}

2011

Primary Supervisor

Dr Nicholas Taylor 


\section{TABLE OF CONTENTS}

\begin{tabular}{|l|l|}
\hline Abstract & 6 \\
\hline $\begin{array}{l}\text { 1.1. Introduction } \\
\text { 1.2. Organisation of the Thesis }\end{array}$ & $\mathbf{7}$ \\
\hline & 10 \\
\hline $\begin{array}{l}\text { Chapter 2: Cooperative Enterprise And Development. } \\
\text { 2.1. Introduction }\end{array}$ & 14 \\
\hline 2.2. Cooperative Enterprises & \\
\hline 2.3. Role of Cooperatives in Development Cooperatives Emerge & $\mathbf{1 6}$ \\
\hline 2.4. Cooperatives in New Zealand & $\mathbf{3 0}$ \\
\hline 2.5. How Cooperatives Develop & $\mathbf{3 4}$ \\
\hline 2.6. Conclusions & $\mathbf{4 0}$ \\
\hline & $\mathbf{4 6}$ \\
\hline $\begin{array}{l}\text { Chapter 3: Methodology } \\
\text { 3.1. Purpose }\end{array}$ & $\mathbf{4 9}$ \\
\hline 3.2. Benefits of research & $\mathbf{4 9}$ \\
\hline 3.3. Approach & $\mathbf{5 0}$ \\
\hline 3.4. Ethical Considerations & $\mathbf{5 1}$ \\
\hline 3.5. Selection of Key Informants & $\mathbf{5 5}$ \\
\hline 3.6. Guided Interview Framework & $\mathbf{5 8}$ \\
\hline 3.7. Document Analysis & $\mathbf{5 8}$ \\
\hline 3.8. Other Secondary Data & $\mathbf{6 0}$ \\
\hline 3.9. Data Analysis and Reporting & $\mathbf{6 2}$ \\
\hline & $\mathbf{6 5}$ \\
\hline $\begin{array}{l}\text { Chapter Four: Social and Economic Context } \\
\text { 4.1. Introduction }\end{array}$ & $\mathbf{7 3}$ \\
\hline 4.2. The Study Area & $\mathbf{6 6}$ \\
\hline 4.3. National and International context & $\mathbf{7 0}$ \\
\hline 4.4.Changes in Rural Economy & $\mathbf{1 0}$ \\
\hline 4.5. Pre Cooperative Period & \\
\hline
\end{tabular}




\begin{tabular}{|c|c|}
\hline 4.6. Foundation Period & 76 \\
\hline 4.7. Transition Period & 80 \\
\hline 4.8. Second Generation Period & 83 \\
\hline 4.9. Conclusions & 85 \\
\hline $\begin{array}{l}\text { Chapter 5. Tracing Organisational Change in the Colville } \\
\text { Cooperative } \\
\text { 5.1. Introduction }\end{array}$ & 86 \\
\hline 5.2. Review of Documents & 87 \\
\hline 5.3. Pre Cooperative Period & 88 \\
\hline 5.4. Foundation Period & 90 \\
\hline 5.5. Transition Period & 101 \\
\hline 5.6. Second Generation Period & 105 \\
\hline 5.7. Conclusion & 113 \\
\hline $\begin{array}{l}\text { Chapter 6. Findings From The Interviews } \\
\text { 6.0. Introduction }\end{array}$ & 114 \\
\hline 6.1. Respondent Demographic Data & 117 \\
\hline 6.2. Findings from the Interviews & 120 \\
\hline $\begin{array}{l}\text { 6. 3. Findings by Cohort } \\
\text { 6.3.1. Pre Cooperative }\end{array}$ & 128 \\
\hline 6.3.2. Foundation & 130 \\
\hline 6.3.3. Transition & 132 \\
\hline 6.3.4. Second Generation & 135 \\
\hline 6.4. Conclusions & 140 \\
\hline $\begin{array}{l}\text { Chapter 7. Analysis and Conclusions } \\
\text { 7.1. Introduction }\end{array}$ & 143 \\
\hline 7.2. Analysis & 144 \\
\hline 7.3. The Colville Cooperative Life Cycle & 147 \\
\hline 7.4. Conclusions & 150 \\
\hline 7.5. Final Conclusion & 152 \\
\hline References & 153 \\
\hline
\end{tabular}




\section{List of Tables}

Table1: Type of Cooperative by Primary Beneficiary

Table 2: Origin of Worker Cooperatives

Table 3: Number of Interview Respondents by Cohort

Table 4: Number of Members 1980 -1989. Colville Cooperative

Table 5: Wages Paid 1987-1989. Colville General Store

Table 6: Number of Members 1990-1998. Colville Cooperative

Table 7: Wages Paid 1990-1998. Colville General Store

Table 8: Wages Paid 2000 - 2010. Colville General Store

Table 9: Life Cycle Phases for Case Study, by Cooperative

Degeneration Model

\section{List of Figures}

Figure 1: Usually Resident Population 1971-1981. Remainder Coromandel CAU

Figure 2: Usually Resident Population 1991-2001. Te Rerenga CAU

Figure 3: Usually Resident Population 2001-2006 Te Rerenga CAU

Figure 4: Organisation Structure. Colville Cooperative Society

Figure 5: Governance Structure. Colville Cooperative Society

Figure 6: Annual Profit and Loss 1979 -1989. Colville General Store

Figure 7: Annual Profit and Loss 2000 - 2010. Colville General Store 


\section{IN MEMORY OF \\ PHILLIP (ANDY) ANDERSON}

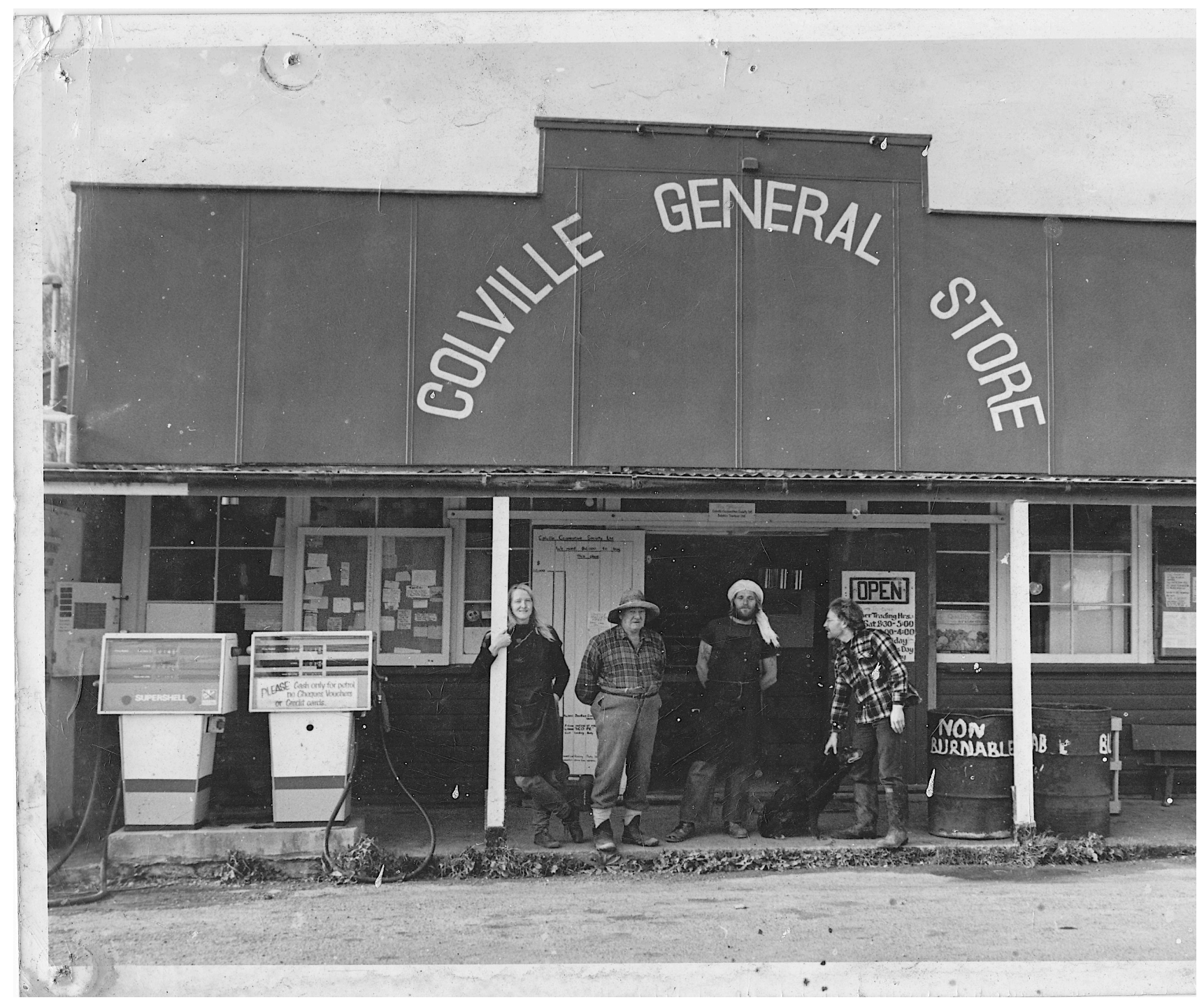

Colville General Store circa early 1980's.

Left to right; Yvonne Vaneveld, Alan Curtis, Alan Shaw-Smith, Phillip (Andy) Anderson d 2008 (Mapua Trustee, and founding member Colville Cooperative Society). 


\begin{abstract}
This thesis seeks to answer the question as to how the Colville Cooperative Society has withstood social and economic change where many other rural businesses offering similar services, in similar rural communities have failed. Joint entrepreneurship is a demanding form of entrepreneurship. Democracy is manage and difficult to sustain.
\end{abstract}

What role does the organisation's cooperative principles and community ownership play in its sustainability? The research seeks to expand the knowledge of community-owned cooperative business as a viable alternative for community economic development; expand the New Zealand research on cooperative models; provide insight for cooperative member's to reflect on past successes and challenges in order to improve practice; and share knowledge about what makes a community-owned business work.

The study found that the sustainability of the Colville Cooperative was dependant on several key factors. First amongst these is that the enterprise provides what the community needs. This is the basis of support for the enterprise and can overcome structural disadvantages. Vision and leadership that cleaves to the cooperative's principles, aims and objectives was just as important. To bring to expression and sustain these there had also had to be adequate business skills, and business continuity.

It is the thesis of this research that the sustainability of the cooperative rests partly in the core beliefs and organising skills of the people who started it, partly in the resilience of cooperative forms of enterprise, and partly in the willingness and capacity of the community to sustain it. It is argued this type of community owned cooperative, where assets and shares are effectively held in trust on behalf of the community, can create a common wealth which frees communities from unsustainable sources of income, and creates viable enterprises that are independent of changing government policy fashions. 


\section{CHAPTER 1 \\ INTRODUCTION AND BACKGROUND TO STUDY}

\subsection{INTRODUCTION}

The Colville Cooperative Society (the cooperative) and its trading enterprise the Colville General Store (the store) is a community-owned organisation built on principles of direct democracy, cooperation and solidarity, community development, alternative economics and environmental stewardship. The store is the primary mechanism through which the cooperative seeks to achieve its social, political and environmental Aims and Objectives.

The study explores the extent to which the cooperative managed to sustain a viable, community-owned rural cooperative enterprise over a period of social and economic change in New Zealand. These changes included the wholesale withdrawal of services from rural areas, restructuring of the rural economy, the rise of neo liberal market driven policies and for Colville, significant demographic change. A casualty of the economic changes is the virtual demise of 'full service' rural grocery stores. ${ }^{1}$

This thesis seeks to answer the question as to how the cooperative withstood social and economic change where many other businesses offering similar services, in similar communities failed. Joint entrepreneurship is a demanding form of entrepreneurship. Democracy is difficult to manage and sustain.

It is the thesis of this research that the sustainability of the cooperative rests partly in the core beliefs and organising skills of the people who started it, partly in the resilience of cooperative forms of enterprise, and partly in the willingness and capacity of the community to sustain it.

\footnotetext{
${ }^{1}$ Many rural grocery stores have become more like corner dairies, selling a limited range of convenience and snack foods and sometimes petrol.
} 
The cooperative exhibits characteristics in common with other cooperatives, and other characteristics that are unique. Its pattern of development has similarities to the lifecycle pattern of organisational development noted in many studies and underpinning the Cooperative Degeneration Theory. On the other hand, survival of a cooperative based on social solidarity principles and born in the last wave of a cooperatives set up in the 1980's is quite uncommon. That movement has comprehensively collapsed. The cooperative's multi stakeholder membership was also unusual for the time it was established.

While not achieving all the goals set back when it started in 1978, the cooperative owns and has successfully managed a commercial enterprise for more than three decades. It employs a second generation of workers. For much of that time the organising power of the cooperative also facilitated community services and environmental initiatives, and was a voice to local and central government for the Colville community.

\section{Purpose of the study}

This study seeks to understand the factors that sustained and hindered the cooperative and store to help development agencies and other small cooperatives develop strategies to ensure community-owned enterprises thrive. Little research has been done about community retail cooperatives in New Zealand, what makes them work and their potential to effect sustainable economic development in poor communities. It provides a New Zealand example operating beyond an aid i.e. government grant or contract, paradigm of development. While at one level a self-help mechanism to address local concerns, at another level the cooperative is directed to a radical agenda of economic and social change.

The prevalence of community-owned resources in the Pacific and amongst Maori communities and organisations suggests a communityowned cooperative model for development which has a close cultural fit in 
its focus and structure; that promotes and enhances autonomy; demonstrates and strengthens sovereignty; and fosters financial independence is relevant to improving development practice in New Zealand and Pacific nations.

The study uses a case study approach and examines the internal dynamics of the enterprise, and the social, demographic and economic context within which the enterprise is located, across a 32 year time period (1978- 2010). The method is detailed in Chapter 3. The study explores the community-owned, cooperative character of the enterprise. It identifies the reasons for the organisation's longevity in the perception of selected members of the cooperative and Colville community; the impact on the organisation's sustainability of internal factors such as organisational structure, governance, decision making processes and management, and external factors such as demographic changes and changes in the rural economy. The extent to which the cooperative has achieved its community development aims and objectives is considered.

The paucity of New Zealand research on cooperatives generally, and small non-agricultural cooperatives in particular, meant international literature was primarily used. The international literature on cooperatives within a development context is itself not extensive. The focus of the New Zealand literature is on the large agricultural and natural resource based cooperatives (Evans \& Meade, 2005). Very limited research on community-owned rural retail cooperatives in New Zealand was identified.

\section{Sustainability}

Sustainability is commonly measured by assessment tools, indicators, measures, and benchmarks, and through a variety of conceptual frameworks, for example, community driven development, participatory methods, empowerment and poverty reduction and capacity development approaches. Tools such as Triple Bottom Line reporting have been widely 
embraced by environment and development organisations in developed economies. $^{2}$

The cooperative represents an alternative articulation of sustainability. It is an organisation whose structure and activities are designed solely to meet the needs of its own community. It adopts no more structure than this minimally requires. The study shows the organisation had no interest in investing in human, technical or management systems to report on its activities. It expected members to know what was going on through being directly involved - a 'lived accountability' model. What happens when this model of accountability breaks down, and the link between lifecycle theories of cooperative development and sustainability of social/community development cooperatives, is examined.

\subsection{ORGANISATION OF THE THESIS}

Chapter 2 provides a background to the tensions and epistemological differences in the cooperatives literature between analysis of cooperatives through an economic or management paradigm, and analysis through a poverty reduction and development paradigm. It identifies the reemergence of cooperatives and examines the characteristics of two very different 'new generation' models of cooperative, framed within a neo liberal modernisation debate.

The reason the United Nations (UN) and other development institutions accept cooperatives based on traditional cooperative principles is because these organisations believe cooperatives to be effective vehicles for community-managed economic development and poverty reduction.

Cooperatives are also a feature of the New Zealand economy and of rural life. Of the world's 300 largest cooperatives, six are in New Zealand. In terms of financial sustainability cooperative enterprises have proven

\footnotetext{
${ }^{2}$ Triple Bottom Line approaches report on the financial, social and environmental performance of an organisation against an agreed set of measurable indicators.
} 
resilient in times of economic downturn (Birchall, 2003; Evans \& Meade, 2005; Fox, 2009; Hazen, 2008; Robb, 2009;) both outperforming and outlasting many investor owned enterprises.

Birchall (2003) suggests member driven cooperative business organisations are the foundation of sustainable development. Cooperatives create organisations of the poor from which other kinds of individual, family and community capacity and development can grow. Cooperative businesses choose how they will engage with the wider economy and are instrumental in the creation of community-controlled strategies against poverty.

Cooperatives represent an ecological, people-centred model of development and a safe form of economy for development (ILO, 2008). Cooperatives have the potential to be effective community organising mechanisms to help reduce persistent social and economic disadvantage and poverty. They can apply social and economic capital that is owned, managed and governed by organisations directly accountable to the communities in which they operate.

The second part of the chapter examines the lifecycle of cooperatives. The Cooperative Degeneration Model predicts a cooperative will move through a sequential, and increasingly hierarchical and complex life cycle from inception to growth, maturity and eventual decline or redevelopment, and that these processes will most likely unfold over many years. There is inevitable loss of democracy and performance as cooperatives become more like investor owned businesses over time (Meister, 1966; Batsone, 1983; Hind, 1999; Cook, 2005; Valentinov, 2007; Cook \& Burress, 2009). The inevitability of degeneration and loss of cooperative values is contested. Evidence disputing the contention is presented. A lack of connection between the cooperative and development discourses is discussed. 
The methodology of the study is described in Chapter 3. The cohort framework for data collection and analysis is explained and consideration given to case study methodology. This chapter identifies the challenge of researching a disorganised but very rich documentary record, and interviewing people living in small communities in which social relations are complex and sensitive. This demonstrates the dynamic interplay between how history is recorded and how it is 'felt' by the people involved.

In Chapter 4 the social and economic context of the case study is explained and the impact on Colville and the cooperative discussed. A brief historical and geographical background of the Colville area is provided to place more recent history in context. The importance of changes in the population, rural economy, and land use, infrastructure and community services from the 1970 s to the present day are examined. It identifies the impact of large supermarket and warehouse style retail outlets in nearby urban centres on a small rural retail business like the Colville General Store.

Chapter 5 examines documents recording the activities of the cooperative and store over a period of 32 years. It provides a background to the reasons why the cooperative was set up and examines the organisation's leadership, governance, and business management. The chapter identifies the contribution made by the cooperative to local economic development, community services and environmental sustainability of a small rural community.

It critically examines trends in the performance of the cooperative, and considers the factors contributing to periods of success and periods of difficulty. This links to findings from the literature review relating to the role of community owned cooperatives in alleviating poverty and improving community, family and individual wellbeing, and to a theory that predicts cooperatives will degenerate in democracy and performance as they grow and mature as enterprises. The findings of the document review are 
considered in relation to the Cooperative Degeneration theory, which is found to have some validity as applied to the research case.

Commentary on documented history is provided in Chapter 6 through interviews with past and present cooperative members and community stakeholders. It is a snap shot of the 'lived reality' and reveals the multiple ways different people understand the same experiences or events. The chapter draws together stakeholder perceptions of the reasons for the cooperative's longevity and its major problems and successes.

Chapter 7 considers the information provided by the examination of the international and New Zealand cooperative literature, the cooperative's own documents, stakeholder interviews and relevant New Zealand social history in relation to relevant theory and how this relates to the research questions. To what extent is the community-owned and cooperative character of the enterprise a key element in its sustainability as a viable enterprise? What factors are instrumental in generating success in the cooperative meeting its aims and objectives and remaining a viable business? What factors undermine these imperatives and generate organisational and business failure?

The chapter analyses the pattern of development of the cooperative across the study period (1978- 2010). It considers the inter-play between the internal dynamics of the cooperative and the social, demographic and economic context within which it is located. It draws conclusions as to the key factors necessary to sustain a social transformation driven, multistakeholder, community-owned cooperative, and comments on the utility of the Cooperative Degeneration Theory as a basis of further study of small cooperatives in New Zealand. 


\section{CHAPTER 2}

\section{COOPERATIVE ENTERPRISE AND DEVELOPMENT}

\subsection{INTRODUCTION}

The following literature review identifies what is known about the development of cooperatives, the contribution they make to sustainable community social and economic development; the reasons why economically marginalised groups favour cooperative forms of organisation; and factors that contribute to the longevity and sustainability of cooperatives.

The hybrid nature of cooperatives suggested an interdisciplinary approach to the review of literature. The literature on cooperatives is fragmented across economics, business management, and more latterly, development policy and practice. Literature on cooperatives from an economics, international development and social economy perspective were reviewed. The primary focus of the review was, however, the literature on cooperatives in development. There is a lengthy economics literature on cooperatives in developed economies and a growing international development literature. At a practice level the literature reveals a plethora of case stories, manuals, how-to kits, leadership training, planning and monitoring tools, and public relations and advocacy information.

In New Zealand there is a general paucity of literature on cooperatives. The literature is largely economic or management analyses of large primary producer cooperatives. Some earlier New Zealand literature focuses on histories of agricultural producer or retail cooperatives. A small number of case stories on work and other small non-agricultural cooperatives were identified. 


\section{Scope of the Literature Review}

The review of cooperative literature canvasses definitions and typographies. It looks at theories about why cooperatives form, the debate about traditional and new generation forms of cooperative, and cooperatives in the development discourse. The role of cooperatives in the New Zealand economy is identified.

The review identified two new types of cooperative, both referred to as 'new generation' but with almost opposite characteristics: a social enterprise model with strong similarities to the research case cooperative, and a capital-intensive corporate model very dissimilar to the research case. The social enterprise model is discussed and compared with key features of the corporate model. Comparison of the two models is framed within a neo-liberal modernisation debate. The review focuses primarily on social cooperatives because of the greater relevance of this form of cooperative to the research case. The literature places the cooperative in history as an early innovator of multi-stakeholder social cooperatives. This type of cooperative appears only recently in the literature where it is described as new and emerging.

The development literature provides insight into why marginalised groups commonly adopt a cooperative form of organising to improve their livelihood. It contributes understanding that the cooperative demonstrates characteristics the literature describes as essential for effective and sustainable community cooperatives. Key amongst these is adherence to genuine cooperative principles and community ownership and management.

The management literature on cooperatives presents a theory that predicts cooperatives will evolve through identifiable stages of change. They will mature from flexible and entrepreneurial enterprises with strong homogeneous member affiliation into structured, management dominated organisations and a conflicted heterogeneous membership. The 
Degeneration Lifecycle of Cooperatives theory is an organisation life cycle approach. It is derived from large-scale studies of both large and small cooperatives. It can be applied to long and shorter-term patterns of organisation change, and to strategic and operational level data. It contributes understanding that the Colville Cooperative, despite some unusual organisation features, has much in common with the development pattern of other cooperatives.

An understanding of the formative phases within cooperatives contributes understanding to how the cooperative has achieved its community development objectives at some points in its history, but not at others. The Cooperative Degeneration theory offers both theoretical and operational utility in addressing the research questions, which centre on sustainability of the research case cooperative. The Cooperative Degeneration theory was chosen for closer review because the relevance of a life cycle approach to cooperative development was strongly suggested by emerging research data.

\subsection{COOPERATIVE ENTERPRISES}

There is little consensus around the definition, determinants, role and benefits of the cooperative forms of enterprise. There is even less consensus about the role of cooperatives in development and in which sector they belong. Cooperatives are hybrid organisations. They are neither private, public nor non-profit but include elements of all three (Dees, 1998; DFID, 2005; Bibby, 2005; Bibby \& Shaw, 2005; Peattie \& Morley, 2008).

\section{Definition}

There is no one universally accepted definition of a cooperative. Some definitions emphasise political and democratic elements of organisation, others emphasise patronage and financial benefits. Others still are functional definitions designed to encompass the wide diversity of 
cooperative forms. The definition adopted by the International Cooperative Alliance (ICA) is widely accepted by international development agencies (DFID, 2005; ILO 2003, 2008).

"An autonomous association of persons united voluntarily to meet their common economic, social and cultural needs and aspirations through a jointly-owned and democratically-controlled enterprise" (ICA, 2007:2)

A functional definition for New Zealand cooperatives attempts to accommodate traditional and newer hybrid forms of cooperative.

"A cooperative is an organisation in which those that transact (i.e. patronise) the organisation also own and formally control the organisation and derive significant benefits from those transactions over and above any financial returns they derive from their investment in the organisation." (Evans \& Meade, 2005:10).

\section{Cooperative Principles}

The ICA derives its principles from the Rochdale Society of Equitable Pioneers (1844) who established a consumer cooperative store in England. The Rochdale Principles are widely accepted and today form the core of the ICA Statement of Cooperative Identity (ICA, 2007; NZCA, 2009; Hazen, 2008; MED, 2010). These principles are voluntary and open membership; democratic member control; member economic participation; autonomy and independence; education, training and information; cooperation amongst cooperatives; and concern for community.

A similar, widely accepted set of co-operative principles derives from the Raiffeisen Union. This developed amongst banking and credit unions in $19^{\text {th }}$ century rural Germany and Austria. The principles include selfreliance, solidarity among members, voluntary participation, flexible organisation, self-administration and internal democracy. Rochdale and Raiffeisen principles dominate within the international co-operative community (Shaw, 2007). 
Some cooperatives reference the emancipatory nature of the core principles to direct a transformative social change agenda. Others seek to maximise profits for members in a similar way to investor-owned businesses (FAO, 1996).

\section{Types of Cooperative}

Internationally the trend in developed countries is for worker ownership to be common in service professions; for farm marketing cooperatives to be widespread in grain production and agriculture; consumer cooperatives and not-for-profit organisations to play a large part in savings bank and life insurance; and worker cooperatives to be more commonly found amongst prosperous white-collar professionals than amongst blue collar workers (Hansmann, 1996). In developing countries cooperatives are commonly found amongst primary producers and the supply of essential services.

The Zeuli et al., (2004) typography (Table 1) is representative of the literature.

\begin{tabular}{|c|l|l|l|}
\hline Type & \multicolumn{1}{|c|}{$\begin{array}{l}\text { Focus of } \\
\text { benefit }\end{array}$} & \multicolumn{1}{|c|}{ Advantage } & \multicolumn{1}{|c|}{ Outcomes } \\
\hline Consumer & $\begin{array}{l}\text { Consumers of } \\
\text { goods or services }\end{array}$ & $\begin{array}{l}\text { Provides good } \\
\text { quality goods or } \\
\text { services at lowest } \\
\text { possible cost }\end{array}$ & $\begin{array}{l}\text { Lowers cost of } \\
\text { goods and services }\end{array}$ \\
\hline Producer & $\begin{array}{l}\text { Producers of } \\
\text { goods or services }\end{array}$ & $\begin{array}{l}\text { Enables self } \\
\text { employed people or } \\
\text { family businesses to } \\
\text { generate market } \\
\text { strength }\end{array}$ & $\begin{array}{l}\text { Makes member } \\
\text { businesses more } \\
\text { productive and cost } \\
\text { effective }\end{array}$ \\
\hline Worker & Workers & $\begin{array}{l}\text { Provides people with } \\
\text { employment and } \\
\text { control over their } \\
\text { labour and work } \\
\text { environment }\end{array}$ & $\begin{array}{l}\text { Creates sustainable } \\
\text { employment, some } \\
\text { rescues private } \\
\text { failing } \\
\text { investor businesses }\end{array}$ \\
\hline $\begin{array}{l}\text { Multi } \\
\text { Stakeholder }\end{array}$ & $\begin{array}{l}\text { Any combination of } \\
\text { workers, } \\
\text { consumers } \\
\text { producers }\end{array}$ & $\begin{array}{l}\text { As above, above, } \\
\text { dependent on } \\
\text { stakeholder groups } \\
\text { involved }\end{array}$ & $\begin{array}{l}\text { As } \\
\text { dependent on } \\
\text { stakeholder groups } \\
\text { involved }\end{array}$ \\
\hline
\end{tabular}

Table 1. Type of Cooperative by Primary Beneficiary (Zeuli, et al., 2004). 
Who owns and benefits from the cooperative, and the intent behind establishing it are important elements in determining cooperative type. In this typography cooperatives as either uni-functional or multi-functional. Uni-functional cooperatives focus on the needs of members rather than the wider community. Examples include producer or worker cooperatives. In contrast multifunctional cooperatives serve the broader community as well as cooperative members. The benefits to the community are intentional and planned. This gives rise to consumer, producer, worker and multi stakeholder cooperatives.

There are various other names and inclusions. The New Zealand Cooperatives Association (NZCA) recognises four types of cooperative: purchasing and shared services; consumer; producer; and worker cooperatives (NZCA, 2010). In common with other UK agencies the Avon Cooperative Development Association (ACDC) (2002) recognise worker, service, marketing and secondary, community, cooperative social firms and consumer/service cooperatives.

Community cooperatives stand out in terms of relevance to the research case. The function of community co-operatives is to provide services to the community and generate jobs. Community cooperatives hold the assets in common ownership and prevent distribution. Members control to what uses the assets are put but they cannot sell or take their shares when they leave the cooperative (ACDA, 2002:1). Village owned shops and food cooperatives are often community cooperatives (ACDA, 2002; Bibby, 2005; McGowan, 2007).

In the economics literature the defining features of cooperatives are ownership and patronage based returns. Evans \& Meade (2005) argue these must form a significant part of the returns members receive, even in new generation cooperatives that allow investment-based returns. Chaddad \& Cook (2003; 2004) also define cooperatives through patronage and ownership rights. The rights to residual (financial) returns are non-transferable, non-appreciable and redeemable. The benefits are 
distributed in proportion to patronage. Chaddad \& Cook (2003; 2004) contrast these features with investor-owned enterprise whose shareholders can transfer or sell their rights to profit in an unrestricted way and do not need to patronise the enterprise other than as an investor.

The differing orientations of the typographies illustrate a division in the cooperative literature between a common wealth and public good discourse, and a traditional economics discourse focussed on individual or member wealth and private good.

\section{Why Cooperatives Emerge}

Birchall \& Ketilson (2009) trace the history of cooperatives in developed economies over the past 150 years and provide evidence that economic crises stimulate their emergence. In the US, Europe and Britain farmers and other producers organised cooperatively to combat loss of income brought about by the collapse of markets during the 1930's Great Depression. Earlier, during the 1840's economic depression, cooperative banks, retail, textile and consumer cooperatives were established in Britain. The cooperative housing movement emerged in urban America during the 1960's in response to the shortage of affordable housing. During the 1970's and 1980's economic restructuring in many developed economies caused widespread unemployment and led to many employee cooperative take-over's of failing businesses. Work cooperatives focused on creating employment also increased. The collapse of the Soviet Union in the early 1990's saw a new wave of worker cooperatives emerge (Birchall \& Ketilson, 2009; Spear, 2000).

This history provides insight into why the literature is dominated by economic theory. The core argument is cooperatives arise because in certain market circumstances they are a more efficient form of organisation. These circumstances include where there is market failure or high transaction costs to doing business. When the competitive advantage disappears, the argument goes, the cooperative will evolve into an 
investor-owned organisation or adapt in a way that makes it like one (Hansmann, 1996; Spear, 2000; Evan \& Meade, 2005). Where there is limited market failure but a strong group of patrons who want to be owners, consumer and producer cooperatives will arise (Hannsman, 1996). Cook (2005) argues people essentially act in self interest and take collective defensive or offense action through cooperatives. Defensive collective action protects the value of the member's assets. Offensive collective action adds value to the member's assets.

The Avon Cooperative Development Association identifies four ways in which worker cooperatives emerge (Table 2).

\begin{tabular}{|c|l|}
\hline New Start & $\begin{array}{l}\text { New enterprise set up to cater for identified niche or gap in the } \\
\text { market. Motivation comes from member's commitment to } \\
\text { cooperative principles and desire for self-help. }\end{array}$ \\
\hline Conversion & $\begin{array}{l}\text { A well-established company converts into a co-operative } \\
\text { because the owners want to pass over or sell ownership to the } \\
\text { workforce }\end{array}$ \\
\hline Rescue & $\begin{array}{l}\text { Workers act to save their jobs by forming a cooperative to } \\
\text { continue an investor owned business that has failed. }\end{array}$ \\
\hline Phoenix & $\begin{array}{l}\text { A new business is created out of the ashes of a failed one from } \\
\text { the still viable parts dragged under by the rest of the business. }\end{array}$ \\
\hline
\end{tabular}

Table 2. Origins of Worker Cooperatives (ACDC, 2002:2)

Spear (2000) links non-profit organisations and cooperatives, suggesting there are strong similarities in why both emerge. Spear focuses on the value of trust and cost effectiveness:

- Higher levels of trust provide lower the cost of decision-making, conflict resolution and sharing information. Lower costs provide a market advantage

- Goods and services are provided at a fairer price

- Community services are more targeted and flexible than state or large corporations

- Lower cost structure and access to donations and volunteer labour

- The influence of policy and regulatory environment on ability to grow

- Networks and organisational choice are more important than entrepreneurship. 
Hannsman (1996) suggests non-profits and consumer-owned enterprises often feature in new enterprises, industries and services. As an industry matures, experience, reputation, standards and regulations develop and this environment favours investor-owned forms of enterprise. Some industries however persist with cooperative forms, for example performing arts and agriculture.

\section{The Modernisation Debate: Traditional v New Generation Cooperatives}

The history of cooperatives in the $19^{\text {th }}$ and $20^{\text {th }}$ centuries has largely been of single-member types, worker, producer or consumer. These are classified now as traditional forms of cooperative (Chaddad \& Cook, 2003; Girard, 2009). The key features of traditional cooperatives, as described by Woodford (2003), are low fees, open membership, limited or no return on capital, one member-one vote, no capital gains and investment that is not based on patronage. For cooperatives with a high degree of member homogeneity the traditional model continued to work well, but as new players have become involved the limitations of traditional models has driven the emergence of a new generation cooperative movement (Cook, 2005; Woodford, 2003).

The essential difference between traditional and new generation cooperatives is openness to non-member private investors, the degree of influence of professional management and the degree of participation of members in decision-making. New generation cooperatives can have non-member investors, professional management exercises a high degree of influence and members have less direct control. (Chaddad \& Cook, 2003; 2004; Girard, 2009; Evans \& Meade, 2005).

During the 1990's and 2000's there was a strong push for cooperatives to demutualise or 'modernise' into private investor-owned businesses. In developed economies, a rise in investor ownership of business and the failure of centrally planned socialist economies led to cooperatives being seen as old fashioned and not sufficiently flexible to meet the challenges of a globalising world. Many cooperatives in the UK, US, Australia, Ireland, Denmark and 
Canada demutualised during this time. Many later failed as investor-owned businesses. Many cooperatives in formerly communist Europe were also privatised. (Birchall, 1998, 2009; Spear, 2000; Shaw, 2007; Birchall \& Ketilson, 2009).

Others agreed cooperatives needed a fresh image but without becoming like private investor owned businesses (Bull, 1999; Spear, 2000). Spear (2000) argued cooperatives needed to respond to the international trend of demutualisation by promoting the unique strengths of cooperative enterprise, which he saw as ethical business practice, innovation and business efficiency. The United Nations Food and Agricultural Organisation (FAO) questioned the right of many organisations to even call themselves cooperatives. They called for a return to principles of democracy, participation, solidarity-based mutual support and local organisations as the basis of true cooperatives (FAO, 1996).

The FAO argued cooperatives in developed countries were too big to be governed democratically, while in developing counties they were largely parastatal. Market and capital liberalisation and growing managerialism were forcing cooperatives to behave like investor-owned businesses and put profit before social benefit and member involvement. There were also as few women involved in decision-making in cooperatives as in any other form of business (FAO, 1996). Davis (2002) agreed increasing managerialism was creating a division between large rich cooperatives and small marginalised cooperatives. Solidarity between cooperatives as a core operating principle was disappearing. Cornforth (2004) suggested a new conceptual framework for the governance of cooperatives was needed, as governance models from the corporate world were not applicable.

Two forms of new generation cooperative emerged from the debate: those that have opened up to non-member investor finance and control by corporate management, and a social enterprise form of cooperative with its roots in nonprofit activities and forms of organising. The first is more like a corporate investor-owned business; the latter more like a non-profit organisation. In the 
1990's both types of new generation cooperative spread quickly in Europe, Canada, United States and New Zealand (Spear, 2000; Evans \& Meade, 2005; Shaw, 2006, 2009; Buglione \& Schulter; 2010). While the corporate model is dominant amongst large New Zealand cooperatives, the social enterprise model has more in common with the research case.

The policy shifts reflected in the rapid emergence of new generation cooperatives are part of wider political changes associated with neo liberal economic paradigms. For large corporate-style cooperative businesses the 'new' cooperative discourse revolves around improving their access to investment capital to grow and compete globally and the maximising of efficiencies and investor/member returns. Girard (2009) for example argues local ownership and community roots are impediments to cooperatives taking advantage of global trade opportunities.

For non-profit sector organisations the 'new' discourse revolves around social capital, rebranding as social enterprises and contracting with public and private institutions to deliver services to the poor and marginalised. (Jeffs, 2006; Spear, 2000; OECD, 2009; Stansfield, 2010). Many social enterprises are appearing as social cooperatives. Advocates of social enterprise consider these hybrid organisations have an important role in addressing unemployment, poverty and exclusion because they can provide more flexible, tailored services (Dees, 1998; Spear 2000; Borzagac \& Defourmey, 2001; Len at al, 2004; Mendell \& Nogales, 2009; Buglione \& Schulter, 2010; Vanna, 2010; Stansfield, 2010).

\section{Social Capital - the Link between Cooperatives and Social Enterprises?}

Social cooperatives derive from a social economy model of enterprise. The emphasis in the social enterprise literature is on civil society and engagement based on participation, trust and reciprocity, and notions of community, collectivism and entrepreneurship. Providing the link between these disparate and contested notions is the theory of social capital. Social capital theory has its own vast literature and is not reviewed here. The role of trust and social 
connectedness, a key feature in social capital, is briefly outlined in order to demonstrate the way social capital is used as a linking or bridging theory to underpin social enterprise ideas.

Putnam (1993) described social capital as the features of social organisation such as networks, norms and trust that facilitate coordination and cooperation for mutual benefits. The literature identifies three key types of social capital. Bridging social capital refers to the building of connections between heterogeneous groups. Bonding social capital is ties between like-minded people and close kin groups. Linking social capital is connections with people in influential positions or powerful institutions (Schuller et al, 2000; Dahal \& Adhikari, 2008). Bonding and linking capital are considered more important in creating social inclusion.

Trust between people is described as a formative element in all forms of social capital; trust has also been found to be a crucial element in the ability of cooperatives to retain customer/member support and maintain cost efficient decision-making through lowering transaction and management costs. These are described as key advantages cooperatives have over other forms of enterprise. The same benefits are claimed for other social enterprises (Batsone, 1983; \& Pencavel, 1992; Hansmann, 1996; Birchall 2003, 2009; Spear, 2000; Logue \& Yates, 2005; Troberg, 2009; Robb, 2009). Social capital is considered a necessary pre-condition of community and economic development (Williams, 1997; Knowles, 2005; Sabatini, 2006; Teaham, 2006; Mansuri \& Vijayendra, 2003; Jeffs, 2006; Vanna, 2010; Mendell \& Nogales, 2009).

Social capital is however a contested notion. Critics argue social capital is conceptually unclear and loosely applied, its claims overblown, and that it is both normative and culturally assimilationist. Networks of trust are just as likely to marginalise and exclude disadvantaged groups and social capital fails to recognise power relations. Transformative political and social solidarity and social movements are replaced by politically centralist, neo-liberal ideas of social capital and social cohesiveness (Schuller et al, 2000; Douglas, 1997; 
Navarro, 2004; Haynes, 2009). The application of social capital theory to cooperatives is problematic for the reason it fails to account for unequal relations of power. Traditionally this is what drives disadvantaged groups to organise collectively to challenge exclusion and unequal power and economic relations.

\section{Social Enterprise}

Social enterprises seek to apply entrepreneurship and business practices to the achievement of social goals. A report for the ASB Trust and Tindall Foundation on prospects for social investment in New Zealand captures the hybrid nature of social enterprises:

"A rough and ready test to determine a social enterprise is that to a traditional charity, they look like a business, and to a conventional business, they look like a charity. This dichotomy reflects the two historical roots of social enterprise". (Saunders, 2009:8)

Not all organisations that are innovative in addressing social issues are social enterprises. Saunders (2009) argues while some are income-generating most rely primarily on grant income and are charities rather than social enterprises. A company set up as a wholly owned subsidiary of a charity which is run as a separate entity to generate maximum profits for the charity is not a social enterprise. Charities with integrated income-generating activities (e.g., a local sports club bar) and social businesses (e.g., Trade Aid) are social enterprises. Although they are set up to meet social objectives and make profits, they are not profit maximizing. The objectives are balanced and business methods and social objectives are fully integrated in the way the organisation operates (Saunders, 2009).

Internationally social enterprises most commonly operate in the arena of essential human services (social care, health, housing, education and employment), filling service gaps left by a retreating state (Peattie \& Morley 2008; Dees, 1998; Borzagac \& Defourmey, 2001. A 2005 study by the Social 
Enterprise Coalition found 53 per cent of UK social enterprises received grants or donations, and 64 per cent had charitable status. Some are trading arms of larger charities (Peattie \& Morley, 2008). Many of the UK social enterprises are charities according to the Saunders typography (Saunders, 2009).

\section{Social Cooperatives}

Social enterprise cooperatives tend to be multi stakeholder cooperatives. Their members are users of the services provided by the cooperative, workers in the enterprise or any person or company who support the organisation's objectives (Spear, 2000; Jeffs, 2006; Mendell \& Nogales, 2009; Girard, 2009; Vanna, 2010, Stansfield, 2010). Some commentators also include single stakeholder cooperatives under the social enterprise umbrella. Len et al (2004), in a discussion about links between worker cooperatives and social movements, suggests worker cooperatives share some values and practices with social enterprises. However, worker cooperatives utilise their independent ownership of economic and political power to create a unique "emancipated social space" (Len, et al, 2004:3). Worker cooperatives succeed in the mainstream market economy, while embracing transformative democratic processes and power relations more characteristic of social movements.

A plethora of new financing models have emerged in response to the rise of ideas about social responsibility of businesses and investors seeking ethical investment vehicles. The alternative financing models include for example venture philanthropy, solidarity finance, and ethical investment, social and sustainable investment. Mendell \& Nogales (2009) concede old financial tools and policies do not fit the needs of social enterprise businesses, but are critical of the poor definition of these alternative financing models. The same criticism is leveled at use of the term 'social enterprise' to describe organisations that actually have big differences in ownership, balance between social and economic goals and degree of democratic decisionmaking. Others describe social enterprise as a repackaging exercise: 
"Social entrepreneurship is a relatively new term which came into being in the 1990's but it is not a new phenomenon and in many ways is a re-packaging of several tried and tested community development approaches such as community businesses, social firms, social enterprises and co-operative trusts. " (Jeffs, 2006:8)

\section{Uncontested Space?}

The literature reveals a largely uncritical embrace of the social economy concept as an idealised alternative economy of collectively governed, democratic, people-centered organisations meeting community identified needs. A small literature adopts a more critical analysis. Critical literatures revolve around the potential of social enterprises to undermine human rights and the public sector, the application of neo liberal economic policies to human services and cooption of non-profits to fill service gaps created by a retreating state. There is an acknowledged lack of robust evidence for claims of effectiveness and efficiency of social enterprises. Social economy is an undeveloped and poorly defined theory and available evidence is derived largely from small-scale, practice-led research (Peattie \& Morley, 2008).

Supporters of social enterprise are not blind to the concept's limitations. Peattie \& Morley (2008) promote social enterprise but agree the research suffers from insufficient data. Spear (2000) is also a supporter but criticises the social enterprise literature as dominated by economic theory, whether this be demand side (state or market failure), supply side (social entrepreneurs, social enterprise) or institutional choice in focus. Spear argues this undervalues the social movement drivers of cooperatives and social enterprises.

A small but growing rights-based critique of social economy and enterprise ideas is evident. The central concern is the undermining of a universal right to essential public services (Farmer, 2008; Cook, et al, 2001). In contracting models of social service delivery the non-profits (or social enterprises) need to 
generate income and a modest profit to be viable. They provide services formerly delivered by government. Charges are put on formerly free services, or contracts to deliver less comprehensive services, at a lower cost and to a set level of demand, are negotiated. An uncritical embrace of neo liberal economic theory by social enterprises entering the 'social economy' can lead to public services becoming cost recovery commodities.

Some of the world's poorest people are charged for essential services like education, health and clean water in order the supply of these is sustainable. In developed economies these services are most often provided as of right and by government, although this has changed in counties like New Zealand where neo liberal economic policies were implemented. Farmer (2008) warns of a commodification of basic services and "perversion of the notion of sustainability" (Farmer, 2008: 26). Social entrepreneurs who work in impoverished communities need a rights-based paradigm that advocates for a strong public sector that confers similar rights. The crucial point for Farmer is social enterprises can never confer human rights.

The critical rights-based view is supported by Cook et al. (2001) who argues OECD country governments have relinquished responsibility to provide full employment and created an unemployed underclass. The unemployed become customers of social enterprises funded by government to provide services to the poor, a "reconstruction of welfare to be achieved through social entrepreneurship" (Cook et al., 2001:8).

Some of these concerns are found in the New Zealand literature. A rudimentary form of social economy enterprise, whereby non-profit organisations contract to government to deliver services formerly provided directly by the state, is common. Jeffs (2006) argues social enterprises are a legitimate form of enterprise with potential to be effective in overcoming social and economic disadvantage, but warns they do not yet operate in an empowering way in New Zealand. Stansfield (2010) also cautions social enterprises to be wary of adopting market economy principles. He reminds non-profit organisations they were born out of the failures of the market. 


\subsection{ROLE OF COOPERATIVES IN DEVELOPMENT}

Development is a contested term so any discussion of the role of cooperatives in development begins with an acknowledgement of the influence of modernisation paradigms on the whole development discourse. Development is characterised by different and conflicting objectives and paradigms. Sustainable development can be framed as ecological modernisation; growth and development is still largely conceived of economic modernisation from traditional, low consumption societies to developed, high consuming societies. Development can have different and opposing meaning applied in different situations.

The New Zealand Cooperatives Association (NZCA) estimates the combined turnover of the world's largest 300 cooperatives is US $\$ 1.1$ trillion dollars, providing more than 100 million jobs (NZCA, 2010) ${ }^{3}$. The combined affiliated membership estimate provided by Shaw (2006) for the three main international associations of cooperatives is 1.068 billion members.

Many cooperatives do not in fact operate on cooperative principles. The FAO (1996) cautioned against an uncritical acceptance of industry estimates of huge numbers of cooperatives and co-operators. FAO cites a World Bank review of rural organisations in Ghana that found only 4 per cent of the registered agricultural cooperatives were actually operating. ${ }^{4}$

“Conferring the term 'cooperative' on any institution claiming to be one, and grouping all such institutions together under a single umbrella category makes it possible to reach fantastic (3.6 billion co-operators) figures which themselves depend on unreliable and frequently inflated national statistics." (FAO, 1996:3)

\footnotetext{
${ }^{3}$ Pers com, Ramsey Margolis, $7 / 7 / 211$.

${ }^{4}$ Review of Cooperatives and Other Rural Organisations in Ghana. World Bank, 1993.
} 
In the New Zealand context, Margolis (2010) has found many organisations registered or claiming to be cooperatives do not in fact operate that way. ${ }^{5}$

Shaw $(2006,2009)$ is cautious in discussing the impact of cooperatives, suggesting evidence of the economic and social impact of cooperatives is thin, cooperatives are extremely heterogeneous and the contribution they make to development very variable and at times, a failure.

Other literature provides current empirical evidence that in terms of financial sustainability cooperative enterprises have proven resilient in times of economic downturn, both outperforming and outlasting many investor-owned enterprises (Birchall \& Ketilson, 2009; Bradley et al 2009; Evans \& Meade, 2005; Fox, 2009; Hazen, 2008; Robb, 2009;). A range of small and large scale studies in developed economies provide empirical evidence of the significant economic contribution made by cooperatives in France, Italy, Canada, US and UK (Craig \& Pencavel, 1992; Estrin \& Jones, 1993; Williams, 1997; Hind, 1999; Nippierd et al, 2002; Bibby, 2005; McGowan, 2007; Plunkett Foundation, 2010; O’Neill, 2010; Melgarejo et al, 2010).

\section{Cooperatives and Poverty Reduction}

Birchall (2003) suggests member driven cooperative business organisations are the foundation of sustainable development. Cooperatives create organisations of the poor from which other kinds of individual, family and community capacity and development can grow, and are instrumental in the creation of community-controlled strategies against poverty.

The hybrid nature of cooperatives examined earlier causes discomfort in the development sector and the non-profit and for-profit sectors. The UK Department for International Development (2005), in considering how to leverage poverty reduction, argues cooperatives do not fit institutional development models or sit comfortably within the development discourse.

\footnotetext{
${ }^{5}$ Pers com, Ramsey Margolis , 1/7/2011.
} 
They are neither private sector, civil society nor social movement, but have features of all three. DFID (2005) decided that cooperatives are part of the private sector and treats them as enterprises Hansmann (1999) agrees cooperatives are part of the private sector and a suitable model of enterprise for both small-scale rural development and large-scale global businesses.

Birchall (2003), ILO (2008) and Birchall \& Ketilson (2009) criticise development agencies as largely overlooking the role of cooperatives, credit unions and other self-help organisations in poverty reduction and sustainable development:

"This cooperative blindness is a stumbling block to drawing on the rich cooperative experience, and to understanding the close fit between grassroot, participatory, community-based development and the power of cooperative people-centred business" (Birchall, 2003: 65)

Scepticism about cooperatives is evident in the development literature from the 1970's through to the 1990's. Cooperatives were associated with authoritarian socialist economies, and with a parastatal role in the developing world. Cooperatives lost goodwill and trust amongst poor communities because of controlling state supervision. They were often neither memberowned nor managed, but rather set up to meet needs identified by governments and other external agents and in order to attract donor subsidies. Governance was poor and often corrupt. (FAO, 1996; Birchall, 2003; DFID, 2005; Shaw \& Bibby, 2005; Shaw, 2006).

The evidence suggests cooperatives frequently fail where donors, governments or development practitioners try to impose them. Cooperatives need to be genuinely member-generated and member-owned. They must be driven by the needs and priorities of members, and be voluntary and autonomous organisations that can mobilise local physical, cultural and human resources. Government and donor involvement need to be kept to a minimum to avoid the more powerful organisation exerting control (FAO, 1996; Birchall, 2003; DFID, 2005; Logue \& Yates, 2005; Shaw, 2006). 
Business skills are an essential capability for sustainable economic development and for successful cooperatives. The importance of business skills is supported in large studies of community economic projects in South Africa (Lochner \& Botes, 2007), Australia (Smith \& Herbert, 1997), and two small New Zealand studies (Boswell et al, 1994; Roopali, et al., 2004). Birchall (2003) argues development practitioners need to know how to utilise cooperatives for development objectives. This means practitioners need a range of small business skills.

Birchall argues cooperatives, as a method of organising and organisational form, fit well with poverty reduction approaches. The strength is the ability of cooperatives to act as a defensive mechanism to shield individuals, families and communities against poverty. Cooperatives are based on principles worked out over hundreds of years by people committed to what is now called sustainable development (Birchall, 2003; 2009). Many cooperatives embody sustainable development principles, being based on values of self-help, selfresponsibility, democracy, equality, equity and solidarity. They are accountable to their members and to the wider community, and corporate responsibility is embedded within the cooperative form of organisation (FAO, 1996; DFID, 2005: Birchall, 2003; 2006; Gibson, 2005; Hazen, 2008; ILO, 2008; Gonzales, 2010). In discussing poverty reduction through self-help, Birchall's 2003 report on poverty reduction for the ILO concluded

"Self help organisations by the poor is a pre-condition to successful antipoverty work and cooperatives can play an important role in this struggle" (Birchall, 2003:1)

Cooperatives facilitate grassroots democracy, encourage local leaders to emerge and enable informal sector workers to organise for self help. They enable small producers to reach markets, the poor to access financial services, and essential services such as electricity, water and housing to be provided where the state fails to do so (UN General Assembly, 1996; DFID, 2005; Spear 2000; Davis, 2002; Birchall, 2003; 2006; Zeuli, et al., 2004; Bibby \& Shaw, 2005; Troberg, 2009; Shaw, 2009; Birchall \& Ketilson, 2009). 
The role of cooperatives in development is increasingly acknowledged in policy and regulatory frameworks. Cooperatives were acknowledged at the World Summit for Social Development and 4th Women's Conference held in 1995, and at Habitat II and the World Food Summit, held in 1996. A UN Economic and Social Council study 'The Status and Role of Co-operatives in the Light of New Economic and Social Trends' (1996) and various UN General Assembly resolutions emphasize the role of cooperatives in social development, poverty reduction, employment creation and participatory development. The UN Secretariat Co-operatives in Social Development Guidelines (2001) and ILO Promotion of Co-operatives Recommendation 193 (2002) promote cooperatives as a foundation of economic and social development. A 2004 Memorandum of Understanding between the ILO and the International Co-operative Alliance focuses on the contribution of cooperatives to help to deliver Millennium Development Goals (Bibby \& Shaw, 2005; Shaw, 2006; DFID, 2005; UN, 2001).

\subsection{COOPERATIVES IN NEW ZEALAND}

In common with other developed economies, New Zealand has a long history of cooperative enterprise. Cooperatives are an established feature of the New Zealand economy and rural life. With a combined turnover of more than $\$ 30$ billion, New Zealand's cooperatives and mutual associations are responsible for 22 - 25 per cent of the country's Gross Domestic Product (Evans \& Meade, 2005; Fox, 2009). Of the world's 300 largest cooperatives, six are in New Zealand (NZCA, 2009).

Cooperatives dominate milk production and the processing of cheese; beef, lamb and venison production and processing; rural supplies; kiwifruit; fertiliser production and distribution/importation, and wholesale grocery industries in New Zealand. Some larger financial services, pharmacy, motor trade, and electricity line owners have also organised as cooperatives. However, these do not dominate the market and usually operate as a type of consumer cooperative (Evans \& Meade, 2005). 
Fifty-four cooperatives belong to the NZ Cooperatives Association (NZCA). With a few exceptions NZCA members are large cooperatives. Corporate primary producer, supermarket and financial services cooperatives are particularly well represented (NZCA, 2010).

Industrial and Provident Society (IPS) and Cooperative Company registrations suggest hundreds of small cooperatives exist in New Zealand. In June 2009 there were 288 registered IPS's according to the Ministry of Economic Development (MED, 2010). While this is a common legal entity for cooperatives to adopt, they can also register as cooperative companies, or register as incorporated societies or trusts but operate as cooperatives. According to Margolis (2010), there were 81 registered cooperative companies in July 2011,30 of whom are associated with NZCA.

Margolis (2011) estimates that probably fewer than 50 of the 288 registered IPS's still exist. This is based this on in-house NZCA research showing most of the cooperatives on the MED IPS Register had not filed an annual return for a decade or more, but have not been removed from the register. Nine IPS's are members of NZCA, and nine member organisations are defined as small i.e. turnover of less than $\$ 2 m$ per annum.

New Zealand commentators acknowledge the difficulty in identifying cooperatives. There is no reliable data from which to identify how many small cooperatives there are in New Zealand, or what type, size and membership they have (Evans \& Meade, 2005; Fox, 2009). The lack of data, especially for small cooperatives, evidences a gap in the New Zealand literature and suggests the benefits of further research. The evidence from the New Zealand and international literature is that small local cooperatives have a significant role to play in generating and sustaining local economic development, particularly in marginalised and poor communities. 


\section{Primary Producer Cooperatives}

In common with the international trends, New Zealand cooperatives also arise in response to difficult economic conditions. The first New Zealand cooperative was an Otago cheese factory and formed in 1871. Cooperatives flourished in the 1860's and 1870's as recession and bank failures hit farmers (Fox, 2009). After World War One dairy prices fell and more cooperatives formed to reduce competition. By the 1930's more than 400 diary cooperatives produced 80 per cent of New Zealand's total dairy production. The three decades 1930 - 1960 were a time of consolidation and by the 1960 's there were only 168 dairy cooperatives. This number had fallen to just 13 by 1995 (Dairy Companies Association of NZ, 2010).

In 1981, speaking at a national meeting of cooperatives, the Federated Farmer's of New Zealand's then legal advisor noted few New Zealand cooperatives would meet the ILO definition of a cooperative (FFNZ, 1981:7). This probably remains the case today. Woodford (2003) suggests most large New Zealand cooperatives have some characteristics of new generation cooperatives, although which particular features they have adopted varies.

\section{Rural Retail Cooperatives}

Rural retail cooperatives appeared in New Zealand from the late 1880s. Government restrictions on trade practices, distribution of goods and competition meant that between 1900-1950 retail cooperatives struggled to become viable. Between 1930 and 1960 many new rural retail cooperatives were formed but few lasted more than a year or two. Of 31 cooperatives set up between 1940 and 1944, only four were still trading in 1969. (Poole, 1969). Poole suggests many rural trading cooperatives had no commitment to cooperative ideals and abandoned their member benefits to survive. However he also notes in the same study that rural grocery cooperatives maintained a "primitive social security system" for rural families in hard economic times, through providing extended credit to customers (Poole, 1969:29). 
In the 1960's there was another surge in retail cooperative registrations, but many either failed to get going or quite quickly went out of business. The future outlook for retail cooperatives in New Zealand was deemed unpromising in 1969 by the New Zealand Institute for Economic Research (Poole, 1969:35). The number of rural retail cooperatives in New Zealand at the time the Colville Cooperative Society was established ten years later could not be identified, but other types of cooperatives were on the rise.

\section{Work Cooperatives}

The number of work cooperatives in New Zealand grew rapidly in the early 1980's. Evans \& McCalman (1982) and Fitzsimons (1982) estimated there were 86 work cooperatives in 1982. "Directions" an early 1980's directory of northern North Island cooperatives published by the Auckland Environment Group provides details for 136 cooperatives $^{6}$. In 1984 the Cooperative Workers Trust (CWT) reported in their newsletter Nga Rongo Korero that there were 300 active work cooperatives or trusts in New Zealand. (CWT, 1984: 39).

Government assistance for cooperatives formed part of the labour market interventions of the time to help combat persistent high unemployment. This gave rise to a range of new types of cooperative, in addition to the more traditional retail and agriculture cooperatives. Horticulture, art and craft, sewing, building, motor repairs, farming, fencing, concreting and market gardening cooperatives became more common (Jones \& Baker, 1975; Evans \& McCalman, 1982; Fitzsimons, 1982).

Government support for work trusts and cooperatives met with varying success. In a study of 12 non-agricultural cooperatives, Evans \& McCalman (1982) found government assistance short term, ad hoc, poorly coordinated, time consuming and complicated. Grant and loan conditions made it hard for cooperatives to become self-sufficient. They identified 22 different schemes,

\footnotetext{
${ }^{6}$ The directory is undated but post 1980 as it lists the Colville Cooperative Society which registered in 1980. The directory was published by CELT, which was most active between 1979 and 1986 .
} 
operating from six different government departments, and very limited nongovernment assistance. The independent Community Enterprise Loan Trust (CELT) Charitable Trust provided a limited number of loans to new cooperatives (Evans \& McCalman, 1982).

The cooperative worker's movement was closely linked to other social transformation movements of the time, amongst these feminism, Maori nationalism, worker rights, and the peace, environment and alternative life style movements. The cooperative worker's movement was made up of many small self-managed cooperatives. It organised nationally through the Cooperative Workers Trust and pursued a radical anti-capitalist, anti-racist, citizen-led democracy agenda. The objective was transformation of the capitalist economic system and labour relations through worker and other forms of cooperative (Jones \& Baker, 1975; Evans \& McCalman, 1982; CWT, 1984; Hackwell, 2007).

Support for worker cooperatives was the beginning of a policy shift toward devolution of government services to non-profit and third sector organisations.

'The workers' cooperative movement sought to validate the needs of the unemployed in terms of the social citizenship discourse of belonging and participation and connect the fulfillment of those needs to the development of a socially useful third sector" (Hackwell, 2007:227).

The policy shift moved the discourse from structural causes for high unemployment amongst Maori, Pacific Island and women, to a residual welfare discourse focused on individual deficits and prescriptions. This excluded the radical discourse of the worker's cooperative movement and in 1986 government support for worker cooperatives was withdrawn under the New Zealand Labour Government New Deal in Employment policy. The focus of this policy was employment training programmes to equip the unemployed to compete as individuals in the labour market (Kelsey, 1999; Hackwell, 2007). 
This policy shift was to lead eventually to a radical restructuring of public services and a retreat by government from free and universal access to services by the privatisation of public services and the creation of "quasi markets'. A social economy model of contracting non-profits to provide social services in the place of government was implemented as part of this policy agenda (Kelsey, 1993; Hackwell, 2007).

\section{Future Direction}

The environment in New Zealand has changed for cooperatives as primary producer cooperatives have consolidated, grown and captured market share, and other types of cooperative have declined. Evans \& Meade (2005) suggest that in contrast to a confused policy environment in the 1980's and 1990's, the current institutional environment for cooperatives in New Zealand is now neutral, relative to other jurisdictions. Tellingly, they describe New Zealand cooperative legislation as flexible, less tied to cooperative principles than corresponding legislation overseas, and free of policy preferences favouring cooperatives over investor-owned enterprise. The cooperative sector in New Zealand has by and large moved away from traditional cooperative principles and embraced 'new generation' principles.

Supporters argue cooperatives are a better form of business and the future face of business in New Zealand. The question is not whether cooperatives as we know them in New Zealand should persist, but rather how to help them grow. Robb (2008) and Fox (2009) argue, rather uncritically, that because cooperatives have an ethical dimension to their activities, and differ in values and principles from investor-owned business, they offer a more ethical business model. That is a contestable idea given a number of large New Zealand cooperatives are monopolies and totally control some basic food items.

Kerr (1999) takes a different view. He believes the benefits of agricultural supply cooperatives are widely over-stated and that "a lingering ideological attachment to cooperatives holds back the New Zealand economy" (Kerr, 
1999:2). Kerr concedes cooperatives have advantages in some circumstances, but argues investor-owned businesses are a type of producer cooperative. Kerr claims cooperatives do not behave more cooperatively than other businesses and points to single-desk dairy product exporting as an example.

\subsection{HOW COOPERATIVES DEVELOP - A LIFECYCLE APPROACH}

Drawing on management and social science organisational life cycle literature, researchers have developed a lifecycle approach to understanding cooperatives. A lifecycle approach predicts an organisation will move through various stages of development from inception to growth, maturity and decline or redevelopment. Lifecycle models that have been tested in small and large studies of cooperatives, and been modified as a result. A life cycle approach is relevant because social and institutional processes that affect cooperatives sustainability may unfold over many years. Through better understanding these processes, choices can be made to address common challenges and improve the sustainability of cooperatives.

\section{Life Cycle Models}

Whether theorists identify a three, four or five stage model of cooperative development is not the most critical aspect of a lifecycle approach. What is more relevant is that cooperatives do seem to go through recognisable cycles. The length of these cycles, and in what sequence they occur, probably varies enormously between cooperatives. A lifecycle approach offers cooperatives a general framework in which cooperatives can reflect and learn from their experiences. It helps them consider what may be coming up that is not yet visible at the day to day level.

The Cooperative Degeneration theory predicts a cooperative enterprise will move through a sequential and increasingly hierarchical and complex life cycle from inception to growth, maturity and eventual decline or 
redevelopment. These processes will most likely unfold over many years. The theory suggests that stabilising processes, norms and structures set up to manage growth eventually become inhibiting to the organisation's ability to adapt to market changes. This leads to conformity, 'group thinking' and eventual dissolution of the enterprise. That is, over time there is an inevitable process of degeneration of democracy, efficiency and performance within cooperatives (Meister, 1966; Batsone, 1983; Hind, 1999; 2005; Valentinov, 2007; Buttress, 2009).

Within this broad theoretical envelope sit a number of differing models. The differences are in the detail though, rather than in the essence. Three, four and five stage models were identified. The similarities between them however, are more striking than the differences.

Meister (1966) conceived of a four-stage lifecycle. He believed democracy and labour orientation within cooperatives eventually degenerate and the cooperative becomes more like the institutions it was set up to challenge. In the beginning there tends to be direct democracy but poorly articulated economic functions. This is followed by transition to conventional organisational principles and practices and increasing conflicts between cooperative idealists and practical managers. Market values slowly become fully accepted, and representational rather than direct democracy is established. A growing gap between managers and cooperative members emerges and finally, managers assume total control.

A study of 60 French cooperatives by Batsone (1983) disproved Meister's belief that cooperatives become like the institutions they initially reject. This study found that pursuit of socialist goals did not affect the economic performance or the survivability of cooperatives. They did not necessarily degenerate into "democracies of small capitalists" (Batsone, 1983; 159). Workers could run their own enterprises with as much success as investorowned enterprises without giving up their political and cooperative beliefs. This finding is supported in other studies carried out in Italy, France, Spain, Norway, Canada and Finland (Craig \& Pencavel, 1992; Estrin \& Jones, 1993; 
Freundlich, 1998; Logue \& Yates, 2005; Melgarejo et al, 2010; Troberg, 2009).

In contrast to Meister's predictable march toward increased managerialism and loss of member democracy, others also believe degeneration is neither inevitable nor a single cycle of decline. Rather than a steady, long-term decline in economic performance, democracy or labour orientation there is a series of repeating cycles of degeneration and renewal. These cycles will be heavily influenced by the characteristics of the local and national economy in which the cooperative is operating. There will be iterative phases and cycles of degeneration and metamorphosis of a cooperative over time. Some capacities such as increased revenue and market share may be gained. Other capacities such as cooperative values and democratic principles may be lost (Hind, 1999; Cook, 2005; Valentinov, 2007; Cook \& Buttress, 2009).

Batsone's 1983 study found evidence of some broad tendencies in the life cycles of cooperatives. Rather than an inevitable path of degeneration, Batsone concluded there was generally a three-stage pattern to the lifecycle. Batsone's foundation stage is characterised by small enterprises that are often short of funds and likely to exercise a rudimentary form of direct democracy. After a few years of financial surpluses being invested back into the cooperative, cooperatives tended to be more secure and the pioneer environment diminished to some extent. This stage often preceded a second stage of increasing professional management and loss of direct democracy.

In the second stage of Batsone's model more administrative systems are put in place, management skills increased, the enterprises grow and more workers are recruited. Not all of the new workers may be cooperative members. More of the financial surplus goes into paying management and less into the cooperative to fund capital investment or replace plant and equipment. Batsone describes this managerial dominated environment as the low point in democracy. 
Batsone's third stage is characterised by the emergence of new leadership, a growth in membership, decline in the dominance of professional management and a resurgence of member democracy in a more mature form. Batsone considered a return to direct member democracy at this stage however was unlikely.

Hind (1999), in a case study of ten UK agricultural cooperatives, ranging in size from 12 - 8,500 members, found key elements of the cooperative lifecycle hypothesis had validity. Hind found that agreement between the major stakeholder groups about the organisation goals declined as a cooperative moved further through the organisation life cycle. In the later stages, when the number of cooperative members had increased, it was the managers rather than the members who most influenced what objectives the organisation pursued.

Hind reports that in the later stages of the lifecycle of a cooperative management goals change the organisation structures and trading practices. These become more like those of an investor owned business than a traditional cooperative. Overall Hind found the assertion that cooperatives become more like investor owned businesses over time had validity (Hind, 1997; 1999).

Cook (2005) and Cook \& Burress (2009) further developed the lifecycle approach, building on the degeneration model articulated by Batsone (1983) and Hind (1999). Their work is derived from studies of agricultural cooperatives in the US and UK and tends to revolve around economic concerns. Nevertheless the theoretical framework of cooperative degeneration they explored also lends itself to application in other kinds of cooperatives. Whitman (2011) for example, applied the framework to a UK coffee trade aid type cooperative and found it had utility and validity.

The Cook \& Burress (2009) model of cooperative degeneration has five stages of development through inception, growth, maturity, decline and demise or redevelopment. The core of this model is largely a re-articulation of 
Cook's (2005) original five-stage model. The five stages are

1. Economic justification. Cooperatives arise from market failure and represent collective action by a group of people to improve their socioeconomic situation.

2. Organisational design. The process of constructing a cooperative constitution takes a lot of energy and tests homogeneity amongst members.

3. Growth and Consequences. Over time member interests diverge and threaten the viability of the organisation. Competing interests increase the cost of collective decision-making, and special interest groups exert pressure.

4. Recognition of conflict. There are fragmented coalitions, a less focused and defined cooperative purpose, increased conflict and less willingness to engage in discussion.

5. Restructure. Members face decisions relating to organisational survival.

The first stage predicts cooperatives will form around common geographic locales, grievances or visions, and amongst relatively homogeneous groups of people. The shared experiences give a strong sense of member ownership, control and commitment, often expressed as a sense of "them against us". Market failure of some kind will encourage people to act collectively to improve their socio-economic wellbeing.

The second stage is a growth stage. More defined and formal processes, policies and structures will be set up to manage organisation growth. The design of the cooperative is built around member homogeneity. Members will be very involved in decision-making processes, and will share risks and responsibilities. More authority will be established, but there will still be flexibility. 
The third stage of degeneration predicts the membership will become more heterogeneous, their interest in the business more varied, and their sources of income more diverse. Member interests start to diverge and the group becomes more heterogenic. The sense of shared grievance will fade, more grievances against the cooperative will surface and special interest groups emerge. This leads to increased conflict and rising costs.

Members begin to fall into four different groups- apathetic members, targets for aggressive rivals, vacillators, and loyalists. The first three categories will grow as a percentage of total members. This marks the beginning of a fourth stage. Collective decision-making becomes more difficult and more costly. The cooperative will be less focussed on its original purpose. Toward the end of this phase members and/or the cooperative leadership will demand action to resolve the difficulties. Democracy will be representational at best; management will have a lot of influence.

In the fifth and last stage the cooperative will face a choice about the survival of the organisation. Cook \& Burress suggest there will be four choices at this stage of degeneration. The first choice is to exit through liquidating, merging or combining with another cooperative, or demutualising. The second choice is to tinker with the structure and make moderate changes in how governance, patronage and capital are represented in the organisation. The third choice is breaking away and spawning another cooperative, and the fourth is to make a radical change by opening up the cooperative to multiple patronage groups, sources of capital and types of governance (Cook, 2005; Cook \& Burress, 2009).

Others also found member interests become more divergent over time. Hind (1999) and Chaddad \& Cook (2004) show cooperatives can expect greater heterogeneity amongst members over time. As the membership grows cooperation often declines. The cost of sending out information and gathering members together increases. Responsibilities become spread between a greater number of people or roles over time, and there is always more 
diversity amongst a larger group of people. These factors mean the cooperative loses flexibility and responsiveness, and is slower to revitalise the enterprise and adapt to change.

\subsection{CONCLUSION}

The literature shows that from its origins as a solidarity movement of the working poor to address unequal labour/capital relations, the international cooperative movement has evolved, but also become divided. The hybrid nature of cooperatives has enabled diversification to the extent there are now almost oppositional models. Cooperatives are as commonly large, globalised and monopolising corporate enterprises as they are small struggling enterprises suffering under globalised markets and monopolies. That both kinds of organisation are able to call themselves cooperatives is a paradox. A third form - the social cooperative - is emerging. These cooperatives are associated with a social economy model of human services delivery and struggle to find their place in the cooperative movement. These organisations look more like non-profits, yet also call themselves cooperatives.

The literature suggests the scale of difference between cooperatives is not particularly well understood or articulated in either the economics or development literature. Economics literature places an over-emphasis on financial goals and an under-emphasis on democracy and community concerns. The development literature under-emphasises financial goals and over-emphasises community concerns.

".. The dual entrepreneurial and associative nature of co-operatives has contributed to their current low profile within research and policy agendas. This duality has been variously characterised as both a fatal flaw and a creative tension." (Shaw, 2006:2)

The duality and creative tension alluded to by Shaw, and the fatal flaw, is well evidenced in the literature. 
There is little evidence from the literature that all cooperatives apply the core cooperative principles, or that this form of enterprise is inherently more willing to deliver the emancipatory outcomes those principles promise. Cooperatives are just as likely to abuse market power and be profit-maximizing as any other form of enterprise. The literature largely ignores differences in power relations between cooperatives. There is no evidence that a cooperative per se is necessarily an organisation with any concern for non-members economic and social wellbeing or justice.

The development literature however strongly suggests cooperatives can be sustainable vehicles for transformative economic and social development, and the reduction of poverty. The argument is predicated on an adherence by cooperatives to the core principles of cooperation, and to community ownership of enterprise.

The literature demonstrates how little consensus there is about the role and contribution of cooperatives to development. Cooperatives probably all start with a committed group of members who share some kind of disadvantage and believe this can be overcome by working collectively. There is agreement that the principles of cooperation and empowerment are central to cooperative identity. What happens to those principles as the cooperative matures and succeeds and the initial social-economic disadvantage is overcome is clearly very varied. Some cooperatives become like the institutions or large businesses they initially oppose while others hold on to more traditional cooperative principles and practices.

Several gaps in the literature are evident. The first is a literature that more clearly articulates the dynamic and often conflicted interaction between a cooperative and the community in which it operates. The impact and dynamism of changing power relations within the community are reflected in cooperatives. This affects its ability to deliver equitable and sustainable development outcomes. This dynamic and its effect on the organisation's performance, is evident in the cooperative examined in this thesis. 
There is a large gap in the New Zealand literature on the features of smallscale cooperatives and their contribution to sustainable local economic development. The thesis provides an initial example on which further research may be built. The application of the Cooperative Degeneration theory to analysis of a small rural retail cooperative provides evidence of its utility as a basis for further research. 


\section{CHAPTER 3.}

\section{RESEARCH METHODOLOGY AND METHODS OF DATA COLLECTION}

\subsection{PURPOSE}

The purpose of the research is to understand better the factors that sustain a community-owned co-operative business. The research examines the internal dynamics of the Colville Cooperative in Coromandel, New Zealand, and the social, demographic and economic context within which it is located. A strength of the research is that development of the organisation is tracked across a 32 year time period (1978-2010).

Adversities that threaten the cooperative's sustainability include internal factors (organisational structure, governance, decision-making processes and management), and external factors (demographic changes, changes in the rural economy). The extent to which the cooperative has achieved its community development aims and objectives is discussed and set within these challenges.

The exploration of the community-owned, cooperative character of this enterprise and the reasons for its longevity is viewed from the perspective of selected members of the cooperative and the Colville community, evidence from the review of internal documents, the literature on cooperatives and from external data sources.

\subsection{BENEFITS}

The benefits of the research include expanding the knowledge of community owned cooperative business as a viable alternative economy for sustainable development. It expands the modest New Zealand research base, especially on small non-agricultural cooperatives and about which there is very little research. In the tradition of community research it also has practical utility in 
helping the Colville community. It provides an opportunity for cooperative members to reflect on past successes and challenges to inform and improve future decision-making and practice. The research provides a mechanism for knowledge to be shared with other cooperatives and social enterprises with an interest in sustainable community owned business.

\subsection{APPROACH}

This research adopts a case study approach, utilising qualitative and quantitative data and mixed methods consistent with an Interpretative Research Paradigm (Taylor, 1990; Williamson, 2000; Goodrich, 2007; Bryman, 2009). The study is of a single case. This approach was chosen because it is best suited to explore the research questions.

A case study offers an opportunity to utilise interview data and document analysis to better understand the dynamic processes of community development. A case study approach is also relevant because

- The complex social context of the decision-making environment within a community owned cooperative business has a major influence on its success.

- Both qualitative and quantitative factors are relevant in understanding why the cooperative has been sustained since 1978. It is important to understand the wider social, political and economic influences on the cooperative and reflect on its performance in these environments.

- There is limited understanding why, despite significant change in local social and economic conditions, the cooperative has sustained itself for more than three decades. In some periods of relatively favourable economic and social conditions the cooperative has come close to financial collapse, yet it has flourished in some less favourable times. This paradox suggests a need to explore to what extent the internal dynamics and structure of the cooperative 
impact on its performance, sustainability, and ability to deliver on its community development and social change objectives.

\subsection{ETHICAL CONSIDERATIONS}

Goodrich (2007) stresses trustworthiness as well as validity and emphasises the need to 'confirm, corroborate, substantiate and support 'data sources through triangulation in order to increase the validity of the data collected and the conclusions flowing from that. Actively seeking out negative cases and rival explanations, and checking the quality of argument being constructed, are emphasised by Goodrich (2007).

The key ethical considerations arising from this research can be summarised as

- Positionality of the researcher

- Confidentiality

- The extent to which findings from a single case study can be generalised

- Reliability of key respondent's memory over an extended time period.

Given these factors, triangulation of the writer's perceptions and data inclusions, and of the key informant's memories of events that may have taken place thirty years ago, led to a research project designed around four descriptive and analytical components as follows:

- Literature review

- Interviews with key informants

- Internal document analysis (the cooperatives own documents)

- Analysis of external data (for example census data, local government records).

Victoria University Human Ethics Committee approved the detailed research methodology, including semi-structured guided interview questions, information sheets and consent forms. 


\section{Positionality}

I was a member of the core group that established the cooperative and operated the store. I served a number of terms on the cooperative's Committee of Management (the committee) between 1980 and 1991, and was employed in the store and cafe between 1979 and 1985. I remain a member of the cooperative, but have not been resident in Colville, or worked in the cooperative, since 1994. While my background provides added insight into the workings of the cooperative and store, it is a possible biasing factor.

The research is informed in part from my 'insider' knowledge of a small closeknit rural community and the cooperative located there. I personally know many key informants. An 'insider' is a researcher who has a lived familiarity with the group being researched and shares with them some key characteristics or experiences. The outsider is a researcher who doesn't have any intimate knowledge of the group being researched before they become involved with them. Community research is not uncommonly 'insider' (Smith, 2002; Rabbitt, 2003: Mercer, 2007).

The benefits of insider research include ease of access, familiarity and rapport. Issues associated with insider research include an increased likelihood of the researcher taking things for granted, assuming the researcher's perspective is more widely shared than is the case, the obvious questions not being asked, the sensitive topic avoided or down played, shared experiences neither questioned nor explained, and assumptions not being challenged (Smith, 2002; Rabbitt, 2003). Others think this typography of issues is false. Mercer (2007) argues researchers move along a continuum of insider/outsider perspectives, with some interview topics increasing the experience of insiderness with the person being interviewed, and other topics increasing the experience of outsiderness.

The nature of the study suggests ethical issues, credibility and triangulation of data sources become more important. Rabbitt (2003) suggests practical strategies for maintaining credibility when conducting research interviews in 
one's home community. These include clear confidentiality agreements; use of pseudonyms; masking of individual descriptive data; privacy during interviews; understanding the potential for unexpected sensitivity by informants to some questions; recognition of potential for bias; and having key informants check interview transcripts. A number of these safeguards are built into the research design for this case.

\section{Confidentiality}

Access to the study data is restricted to the principal researcher and her supervisors. It is kept in a password protected electronic file and locked cabinet. The data will be destroyed after two years (by December 2012). Informed consent to use the data collected was obtained from interviewees and the cooperative.

\section{Individual Confidentiality}

Key informants living in Colville expressed a desire to remain anonymous as a condition of their participation in the research. The potential for negative social impacts arising from the smallness of the community and legacy of past conflicts between some cooperative members is recognised.

The researcher and each key informant signed a confidentiality agreement. This set out the confidential nature of the data, how it was to be used, who would have access to it, and how it would be protected and stored. Consent was sought for the collection and use of the data for conference and academic papers, and for inclusion in the thesis. The data is confidential and was viewed only by the researcher and her supervisors. The data write-up is in an aggregated form so no individual is identified.

Any direct quotes used in the study are attributed to a role, for example longterm community resident, worker, and committee member. Over the time covered by the study, a number of different people have filled these roles. The total number of individuals involved in the cooperative over the past 32 years 
is estimated to be at least $150^{7}$. This helps ensure no individual is identifiable, despite the study being of a single organisation.

\section{Organisational Confidentiality}

The name of the organisation is not confidential. As the subject of the case study the Colville Cooperative Society Ltd is clearly identified.

Permission to access cooperative documents was obtained. An Information Sheet relating to the release and use of the documents was provided. A confidentiality agreement setting out how the data was to be collected and used was provided, discussed and signed by the researcher and each respondent. This agreement included a guarantee no document relating to confidential employment issues would be viewed, copied, archived or used in any way by the researcher.

Where it was possible to establish the original source of photographs, this is acknowledged.

\section{Validity}

The in-depth study of one cooperative provides insight into why this particular enterprise has been sustained over time, and what it may have in common with international examples of successful cooperatives. Reliability and validity concerns common to small sample qualitative research are mitigated in the research by the triangulation of data sources.

There is a wider issue of how generalisable the results of one case study can be. Williamson (2000) argues the findings from a single case frame can help develop an explanation of why something happens, and may be generalisable to another research setting which tests the findings. Knowledge and

\footnotetext{
${ }^{7}$ Membership records for the cooperative are partial and incomplete. The figure of 150 is an estimate based on the cooperative's membership records, record of directors held by the Registrar of Industrial and Provident Societies, and the recollections of key informants.
} 
understanding is thus built over time. Single case studies are common in community research.

The study seeks to identify critical factors for sustainability in small community-owned cooperatives in a New Zealand context, with a view to further exploration through subsequent research built around a broader comparative set of cases. No such New Zealand based research exists and there are few available cases for longitudinal analysis.

\section{Reliability}

A further consideration is the reliance on key informant's memories of past events. Mitigation of this issue is built into the research design. Triangulation of data sources reduces the likelihood of obvious errors of fact. Differences in interpretation of the same events are helpful in achieving a balanced analysis and interpretation.

\section{5. SELECTION OF KEY INFORMANTS}

A cohort frame guided the selection of key informants and the interview framework. The respondents form four cohorts of former and current cooperative members and employees, and one cohort of long-term Colville residents who have never been members of the cooperative. The cohorts are: Pre-Cooperative (prior to 1978); Foundation (1979 -1989); Transition (19901999); Second Generation (2000- 2010); Community (1979 - 2010).

The cohort's are made up of a range of people who together report on the whole 32 years of the study period.

\section{Description of cohorts}

- Pre Co-operative: members of the former Colville food cooperative, residents in Colville prior to 1978, and founding or early members of the cooperative. 
- Foundation members: the pioneers who started the cooperative, and ran the store as a worker cooperative.

- Transition members: the group of people who took over the reins as Foundation members withdrew.

- Second generation members: the current group of people who govern the cooperative, and work in the store.

- Community residents, not cooperative members: long-term residents of Colville who have never been members of the cooperative but have been customers of the store for many years.

The cohort frame was populated by data derived from key informants, the cooperative's own records, the historical list of directors held by the Registrar of Industrial and Provident Societies, and my own knowledge of the organisation. The cooperatives own records are incomplete and needed to be supplemented in these ways.

\section{Sampling}

Within each cohort, purposive sampling ${ }^{8}$ is used to select interview respondents. This is supplemented by opportunistic ${ }^{9}$ sampling as insight was gained through fieldwork into other key informants who should be interviewed. Purposive sampling is based on three key factors and aimed at ensuring a representative spread across roles and across time:

- The individual's primary role in the cooperative, for example governance, administration, shop worker, financial administration

\footnotetext{
${ }^{8}$ The selection of key informants judged to be most representative of cooperative members and workers in the business over the selected time periods.

${ }^{9}$ Identification of other key informants which emerge through field work interviews.
} 
- A balance between individuals who took leadership roles in the cooperative, and those who had lower profile roles

- Period of time the respondent had been active in the cooperative.

Selection of long-term residents who have never been cooperative members was on the basis of men and women who have a profile in the Colville community. Sampling is therefore purposive in two ways: over time and by role.

Opportunistic sampling supplemented the initial cohort selection. This is to ensure a balanced and representative selection of time periods. Contact with potential respondents was made through an initial phone call or personal visit, followed up with an introductory letter and information sheet. All interviewees were previously known to the researcher.

\section{Cohort Respondents}

All of the eleven people interviewed are part of more than one cohort (Table 3 ). This reflected the relatively long time most people had been involved in the cooperative.

\begin{tabular}{|l|c|c|}
\hline Cohort & Time Period & $\begin{array}{l}\text { No. of Respondents by } \\
\text { Cohort }\end{array}$ \\
\hline Pre Cooperative & $1970-1978$ & 5 \\
\hline Foundation & $1979-1989$ & 7 \\
\hline Transition & $1990-1999$ & 4 \\
\hline $2^{\text {nd }}$ Generation & $2000-2010$ & 7 \\
\hline Community & $1978-2010$ & 2 \\
\hline
\end{tabular}

Table 3. Number of Interview Respondents, by Cohort.

The total number of respondents is 11 . Each respondent falls within more than one cohort. Eight women and three men are interviewed. The gender balance reflected the traditionally high percentage of women who have worked in the cooperative. The respondents range in age from 39 to 82 years. 
Detailed demographic data relating to respondents is included in Chapter Six: Findings from the Interviews.

\subsection{GUIDED INTERVIEW FRAMEWORK}

In-depth, semi-structured interviews were conducted. The guided interviews sought both qualitative and quantitative information. Semi-structured interviewing allowed for probing of emerging issues and divergent perspectives and proved well suited to soliciting information and understanding the complex environment within the cooperative.

The interviews explore broad topic areas in a mix of open and closed ended questions, asked in a conversational format. Background information about the respondent (age, gender, educational attainment, current residential location, number of years involved in the cooperative, roles held and current membership status) was obtained.

The questions explore respondent perspectives on internal aspects of the cooperative (leadership, governance, finances, structure and decision making) and its impact on the community (social, environmental, and local economic development).

Interviews with long-term residents who have never been members explore a wider view of the cooperative (relationship with community, support from different parts of the community and impact on the community). A keyword system through which to organise the large volume of respondent data was adopted. The key words followed the subject areas of the interview questions and were used to analyse key themes.

\subsection{DOCUMENT ANALYSIS}

In order to understand the context of the data provided through interviews and identify any other explanations for the phenomena described by the respondents a review of the cooperative's extensive internal documents was 
undertaken. This confirmed key facts, identified the most significant business and governance decisions, identified broad trends in membership, governance and financial performance and obtained further information about the changes occurring in the community and local economy. No statistical tests were run to prove correlations on data obtained, the focus being on identifying and examining issues.

The documents reviewed include

- Colville Cooperative Society Register of Members

- Minutes of the Cooperative's Annual General Meetings

- Annual accounts for the Colville General Store Ltd

- Minutes of the Cooperative's Committee of Management meetings

- Letters and other correspondence with third parties

- Historical photographs

- Personal testimonials relating to the cooperative's dealings with ethical investors

- Originals of founding documents, sale and purchase agreements incorporation of legal entities and loan agreements

- Internal memos, minutes of staff meetings, and

- Other reports and miscellaneous documents.

\section{Issues with Internal Data}

There is an extensive collection of internal documents. The study period is a long one and the volume of documents to review significant. The historical documents had never been filed, archived or otherwise stored in an organised way. This made the review more time consuming and complex to track related documents in disparate locations.

The governance records are extensive and largely complete. However membership data for only 20 years was identified (1980-1998, and 2005), and there are issues of reliability. Alternate Registers of Members were found for 
1986, 1991 and 1998. The current Register of Members is not up to date and some past ones were missing.

Financial data included the annual accounts for Colville Cooperative Society and Colville General Store Ltd, financial notes to applications for loans and grants and calculations prepared by the cooperative's accountant. Financial records for 24 of the 32 study years were identified (1979 -1981: 1983 - 1989: and 1996 - 2009). Despite exhaustive enquiries no financial data was found for eight years (1982, 1995, and 1990 to 1995).

The annual accounts of the store are the primary financial data source. In comparison to the million dollar annual turnover of the store, the cooperative's annual income is modest. Its sole revenue earning activity is the store. The store annual accounts were analysed for annual profit and loss trends, changes in stock value, profitability, major cost centres and wages.

Employment data for 15 years of the cooperative's history were identified. The quality of the employment data varied from high quality audited data through to estimates, working papers for annual budgets, cash flow projections, staff rosters and governance records. This data was cross-referenced with respondent reports where possible.

A rich source of correspondence with third parties was particularly helpful in establishing the cooperative's role in community support and environmental protection.

\subsection{OTHER SECONDARY DATA}

External data sources included the Registrar of Industrial and Provident Societies and Registrar of Companies, local council reports and planning documents, census data, independent research reports, theses, tourism data and other sources that describe the changes in social, demographic and economic conditions in the Colville area and Coromandel Peninsula over the 
period of the study. This data is examined in Chapter 4: Social Context, and in Chapter 5: Review of Documents.

\section{Issues with Other Secondary Data}

Comprehensive and quality demographic data are difficult to obtain. Between 1987 and 2006 significant changes were made to the boundaries of the census area units and mesh blocks covering the study area. The number of very small settlements in the study area also meant some data is withheld by the Statistics New Zealand for reasons of confidentiality.

Historical population and recent census data are ill-matched to actual settlements. This caused Thames Coromandel District Council (TCDC) in 2009 to re-configure available census data for their own planning purposes. The TCDC provided reconfigured basic population data from the 1991, 1996 and 2001 census, and detailed demographic data from the 2006 census (some data withheld). ${ }^{10}$

Census data for 1971, 1976 and 1981 was collected over a single large area unit stretching well south and east of the study area, and known as Remainder Coromandel District. This area unit included all the rural hinterland but excluded the larger towns (Bedogni, 1983). The data inevitably overstated the population for the smaller research target area, but does show the growth trend for the rural hinterlands, including the target area. This was useful in confirming population trends alluded to by TCDC planning documents from the time, and by interview respondents.

The Te Rerenga Census Area Unit now covers Colville and the northern Coromandel, however this also includes Coromandel town (3000 pop) and other settlements distant from Colville. The TCDC has population data of varying level of detail for 1991-2006. For the 2006 census, eight mesh blocks covered the study area. The TCDC provided good quality data for this census.

\footnotetext{
${ }^{10}$ Pers com, Christine Tyne, TCDC 28/9/2010
} 
Of the eight census carried out over the study period, 1986 is the only one for which no data was accessed. The Resident Population figures for 1991, 1996 and 2001 are over comparable area units and mesh blocks, but cover an area slightly larger than the study area. The variation is probably in the order of 2030 people. The mesh blocks changed again in 2006 and do represent the study area, with the exception of one small block withheld by Statistics New Zealand and containing somewhere in the order of 20 people.

From the available data, graphs indicating the Usually Resident population between 1971 and 1981, and between 1991 and 2008, were generated. These are presented in Chapter 4 but in light of the data comparability issues these illustrate general trends only $1970-1981$, and approximations of Usually Resident population 1991 - 2006.

\subsection{DATA ANALYSIS AND REPORTING}

The inevitable variety and volume of interview data was managed through a structured content analysis to identify themes and patterns, using the cohort frame and a key word coding system to organise and compare data.

Triangulation was strengthened by the use of the cohort time periods to organise data from the four key sources

- An examination of the social and political context derived from secondary data

- Primary data from respondent interviews

- Data from the review of the Colville Cooperative's internal documents

- Census derived demographic data.

\section{Relative Importance of Data}

The review of the cooperative's documents proved a very important source of data, more so than the interview data. The documents mainly confirm respondent reports and provide far greater detail than they were able to 
remember. In other cases the documents disagree with respondent reports. This is particularly the case in relationship to the financial performance of the store and, in the case of Second Generation respondents, the environmental records and aims and objectives of the organisation. Lack of triangulation in these respects has to be considered in the light of individual reputational interest, and how far from its founding cooperative principles, aims and objectives the organisation moved in the Second Generation period.

Secondary data describing the national and international social and political context was important in locating the cooperative within a broader social movement. Other cooperative research helped identify it as a rare survivor of a type of cooperative popular in the 1970's, and as an early pioneer in social enterprise. New Zealand research on restructuring of the rural economy contributed important understanding to respondent's experiences of community change.

Census data was generally less important because of reliability issues discussed previously. It was very important however in quantifying population growth and decline and periods over which this occurred. Comparing periods of population change with cooperative performance and reported and documented community change gave insight into the degree of adaptability demanded of the cooperative in order to remain viable.

\section{Summary}

Overall the approach adopted for this study allowed for multiple sources of data to be generated and compared.

The approach gives 'voice' to individuals' experiences of cooperation and community. It provides an opportunity to reflect and analyse on an important formative experience. This strength is also a limitation. A long time has passed since some of the events and memories have faded. Recollections of the transition period of the 1990's were particularly slender. Reputational concerns may also have influenced respondent recall of some events. 
A close relationship between research design and the literature is demonstrated in this case. The literature demonstrates a life cycle approach to the analysis of cooperatives has proved valid in other studies. The cohort frame of the study also was adapted from this approach. The cohort time periods in which data is analysed here are not an exact match to the stages of degeneration of cooperatives but do strongly suggest distinctive life stages and repeating cycles with key characteristics of the degeneration theory.

The lack of high quality demographic data for all but one of the census periods of the study was a limitation. Better demographic data would have reduced the need to find alternate and less reliable sources. Nonetheless, a strong picture of the social context of the case study emerges in the next chapter. 


\section{CHAPTER 4}

\section{SOCIAL AND ECONOMIC CONTEXT. THE TIMES THEY ARE A CHANGIN'.}

\subsection{INTRODUCTION}

This chapter identifies the major social, cultural and economic trends prior to, and contemporaneous with, the operation of the Colville Cooperative Society (the cooperative). Understanding the context in which the cooperative was established, and the impact of change on the Colville community both anchor and inform this research.

The chapter provides context important to locating the research case within the wider environment from which it emerged and has operated for more than three decades. National and international social, political and economic trends influencing Colville and the Colville Cooperative are identified.

The first section of the chapter introduces the case study cooperative and the physical geography and community within which it is located.

The second section examines the prevailing national and international social and political movements that influenced the cooperative founders and early members. It locates the cooperative within a movement for radical social transformation.

The balance of the chapter identifies major social and economic change in rural New Zealand, and in Colville, in the decades immediately prior to and contemporaneous with the cooperative. The data on the nature and effect of change on community attitudes and levels of social cohesion is organised under the four cohort periods of the study. Population and other demographic 
data, and social and economic changes from the 1960's to 2009 are presented.

For the sake of clarity and ready identification, the study area is referred to throughout as Colville. This is inclusive of the village of Colville, the far north Peninsula coastal settlements, and the farms and alternative lifestyle communities scattered in the valleys and hills of the rural hinterland.

\subsection{THE STUDY AREA}

The cooperative wholly owns Colville General Store Ltd (the store) and is located in the far northern Coromandel Peninsula village of Colville. In common with other cooperatives it operates a revenue-generating business. Unlike most cooperatives however, it is entirely focussed on community development objectives rather than individual shareholder benefits. The store is a small to medium sized enterprise (SME) with a turnover of between $\$ 700,000$ and $\$ 1.2 \mathrm{~m}$ per annum. The store provides part-time work for up to 20 people in peak summer periods, and 5 to 10 people over winter.

The area serviced by the store stretches from the village of Colville, 28 kilometres northward to the tip of the Coromandel Peninsula and the settlements of Otautu, Port Jackson, Waikawau, Port Charles and Tuateawa. The village of Colville is a scattered settlement of 20 houses, a general store, postal delivery centre, primary school, play centre, social service centre and community hall. Since 2004 there has been a part-time general practice health service. Coromandel town (pop 3000) is 26 kilometres south of Colville village and over 50 kilometres from the northern tip of the peninsula.

Historically, the economy of the north Coromandel Peninsula has relied on a rich supply of natural resources for both Maori and European settlement. Agriculture, forestry and extractive industries remain the mainstay of the local economy. Extensive pastoral activity on the hill country and limited dairying on river and coastal flats was characteristic of the area until the 1960's (Bedogni, 1983). 
Prior to the new wave of settlement in the 1970's and 1980's Colville residents were mainly employed in farming, forestry and fishing, or rural support services. The range of economic activities expanded as the population grew to include arts and crafts, subsistence farming, bee keeping, building and construction, weaving, alternative power systems, adult education, retail and accommodation services. Micro business activities became a common means of production and livelihood. Despite this breadth of economic activity it remained an area of high unemployment because of the seasonal nature of available work, the distance from markets and the limited number of sales outlets. The area was characterised by limited employment prospects, poor housing, and low family incomes. Currently Colville has an aging population with poor health status and there are a large number of absentee landowners.

Colville experiences a large influx of summer visitors ${ }^{11}$. Over the peak New Year period the population swells from a normally resident population of 306 people, to more 3000 people (Statistics NZ, 2006; TCDC, 2008). Visitors play an important role in the store's financial viability. Despite the high visitor numbers, a third of all the council's unsealed roads are in Colville. The main road between Colville and Coromandel town was not sealed until 1990 (Colville Historical Society, 1990; TCDC Long Term Community Plan, 2009 2019). Contemporary tourist literature describes Colville:

"A quaint rural village, once capital of 1970's hippy culture and supply base for alternative lifestyle communities" (New Zealand Information Net, 2009).

Colville is the gateway to a remote rural area of natural beauty. North of Colville the Coromandel Peninsula is mountainous and narrow. Coastal forest fringes rocky coves and sandy beaches. Settlements are relatively remote from one another. The land is mainly in large holdings: farms, conservation, group-owned bush blocks, forestry, reserve or Department of Conservation Farm Parks. A relatively small number of residential sections and lifestyle

\footnotetext{
${ }^{11}$ Thames Coromandel 07/08 Peak Population Survey. Thames Coromandel District Council. 2008.
} 
blocks centre around the coastal settlements of Colville Bay, Waikawau, Otautu Bay, Little Bay, Tuateawa, Port Charles and Port Jackson.

The development aspirations of the residents are recorded in council planning documents as small-scale, environmentally sensitive development to boost economic development. ${ }^{12}$ Constraints on development include a lack of petrol supplies, summer labour and affordable housing. Telecommunications and electricity infrastructure are poor. Rates are high in order to maintain the infrastructure for the large number of absentee landowners and summer visitors, and small businesses struggle to cope with summer demand. An aging population puts pressure on social services and facilities (TCDC, 2006; Beca et al., 2007).

\subsection{NATIONAL AND INTERNATIONAL CONTEXT}

\section{Social Movements}

The period in which the cooperative was established was a time of social and economic change. Old social, economic and political certainties were swept away as large-scale national and international movements for social and political change gathered momentum in the 1960's and 1970's. Equally significant economic changes were on the horizon.

Internationally, cooperation and collectivism were enjoying a revival driven by a 'youth revolution' in developed western societies during the 1960's and 1970 's. This revolution was characterised by a rejection of conventional lifestyles, dissatisfaction with consumerism and a search for simplicity and social experimentation. Developed economies experienced high unemployment, large scale restructuring of businesses, sky rocketing interest rates, increased business amalgamations and numerous financial bail-out's by government of failing institutions and corporations.

${ }^{12}$ TCDC, Coromandel Peninsula Blueprint Economy Profile Statement 2006. 
There was an international revival of interest in cooperatives. In the developing world, poor agricultural producers formed cooperatives. Kibbutzim were established in Israel. The high cost of housing in the United States, United Kingdom and Europe led to the emergence of housing cooperatives. In the economically depressed Basque region of Spain, the widely known Mondragon worker cooperative flourished. Alternative economies and the cooperative organising power of the poor and the marginalised were important issues in the development debate (Sen, 1966; Fletcher, 1975; Fitzsimons, 1982; Freundlich, 1998).

Nationally there had been a wave of new political movements in New Zealand. This was the era of hippies, anti-Vietnam war protest, feminism and emerging Maori nationalism. The 'back-to-the-land' movement was an expression of anti-authoritarianism and anti-establishment sentiment by young people and gave rise to increasing environmental activism (Jones \& Baker, 1975: Grigg, 1987).

Until its defeat in 1975, the New Zealand Labour Government had supported an alternative rural land settlement scheme. The Ohu Scheme, set up in 1975 by the then Minister for Lands, Hon. Matiu Rata, envisaged a revitalisation of society by giving disaffected young people the opportunity to be involved in group living and work on the land.

"The over emphasis on the gross national product, perpetual greed, speculation, profiteering, unethical practices and the cult of individualism can only result in further alienation of those who seek a return to community and group feelings." ～(Matui Rata, quoted in Jones \& Baker, 1975:131)

The defeat of the Labour Government and election of the 1975 - 1984 New Zealand National Government heralded a change in economic policy and a new political environment. Robert Muldoon's leadership was characterised by protection of traditional primary and manufacturing industries and rejection of the liberal social policies of the previous Labour Government. Subsidies to enable New Zealand farmers to compete with heavily subsidised British meat 
and wool farmers were introduced and import tariffs strengthened. As a result of hugely expensive agricultural subsidies, Think Big industrial projects and oil price increases, New Zealand acquired very high current account and budget deficits. This opened the way for a radical restructuring of the New Zealand economy by the incoming third Labour Government in 1984 (Gill, 1989; Easton, 2009).

Jones \& Baker (1975) provide a snapshot of alternative lifestyle groups in New Zealand around the time the cooperative was formed. They interviewed members of cooperative schools, business enterprises, publishers, organic producers, urban communes, subsistence agriculture, craft production, and food cooperatives around the country. What these people had in common was a desire to form new kinds of community and social relations and, as a natural extension, alternative forms of work and economy. They were part of a national movement for social, spiritual and economic renewal of a New Zealand that was more simple, self sufficient and natural. In part, this movement was a reaction to rising consumerism and distrust of neo-liberal economics; in part a desire to protect wild environments and to live a healthy life away from the stress of urban environments. For Jones \& Baker, cooperatives were the basis for an alternative economy:

"There is no reason why every necessary industry and business operation could not run as a co-operative”. (Jones \& Baker, 1975:99)

New Zealand had a large number of mainly agricultural cooperatives at the time. However the types of cooperative Jones \& Baker documented were founded on environmental and community life principles, or on Marxist principles, and had little in common with the large cooperatives formed as associations of individually owned, for-profit businesses.

\subsection{CHANGES IN THE NEW ZEALAND RURAL ECONOMY}

Prior to the 1960's there had been relatively little direct government assistance to farmers but from the 1960's until the mid 1980's farmers 
enjoyed a high level of government protection through subsidies, fixed exchange rates and tight regulation of marketing. Government established producer boards to control the marketing of primary produce e.g. NZ Wool Board (1921), NZ Dairy Board (1961). The farmer-controlled producer boards shielded farmers from changes in international prices and markets. Exports of agricultural products to Britain fell from 55 per cent of New Zealand's production in 1966, to 10 per cent in 1985. After 1973 the government increased subsidies to farmers in an effort to prop up the country's struggling export-dependent economy. By 1984 an estimated 30 per cent of farm output was dependent on government support (Rae et al., 2003; Robertson et al., 2007).

New Zealand's economy struggled with an over-valued exchange rate, high overseas borrowing, falling export sales, high inflation and sharp rises in oil prices (Easton, 2009). The economic problems culminated in a snap election and change of government in 1984. The New Zealand Labour Government undertook a programme of extensive economic restructuring from 1984 1990 based on market liberalisation, corporatisation and privatisation of state businesses, tax reforms favouring higher income earners and a withdrawal from social and other services. This was the beginning of a fundamental restructuring of the rural economy as part of the wider programme of economic reform (Kelsey, 1993; MAF, 1994; Rae et al., 2003; Robertson et, al., 2007; Stockwell, 2009; MacKay et al., 2009).

The withdrawal of agricultural subsidies led to a dramatic fall in rural incomes. Between 1986 and 1988 many farming families faced severe financial hardship. Many public services were privatised, including post offices and other social services. There were downstream effects on other rural businesses. Farming families stopped spending on non-essential items and deferred maintenance of farms and farm equipment. Rural women began to take up off-farm employment in order to bolster household income (MAF, 1994; Rae et al, 2003; Robertson et al., 2007; Stockwell, 2009; MacKay et al., 2009). 
Through the 1990's and 2000's successive National and Labour governments continued neo-liberal rural policies. In many rural areas new land uses and products emerged and rural tourism grew. Many farms were amalgamated or converted to higher value commodity production. Some rural areas also declined. Multiple job holding by rural men and women increased both on and off farm (MAF, 1994; Robertson et al., 2007; Taylor et al, 2007; MacKay et al., 2009).

More recent changes have also affected rural businesses. The advent of Big Box Retailing (BBR) described by Stockwell (2009) demonstrates the impact of large-scale retail businesses on SME rural retail businesses. Stockwell found that population decline, retail convergence and the arrival of BBR's were the three most significant factors affecting the survival of rural businesses during the 2000's. Most affected are family owned and small businesses, especially butchers, bakers, petrol, florists, newsagents, fish shops, liquor outlets, pharmacists and garden centres. In the case of Colville, there is a large Four Square supermarket in Coromandel town only 20 minutes drive away. Pak $\mathrm{N}$ Save opened a store in Thames in the early 1990's; this was followed by a Warehouse and other chain outlets. A large New World supermarket opened in Whitianga in the 2000's. These have all affected sales at Colville Store.

\section{Changing Role of Rural Women}

In the 1960's and 1970's a new wave of urban women's liberation groups emerged but it wasn't until 1976 that a group of rural women appeared at the 1976 United Women's Convention. They presented a paper called "What Is a Rural Woman?".This was based on a national survey of rural women for Women's Division Federated Farmers (WDFF) and carried out by Canterbury University. The paper described the lives of rural women and calls for better rural social services and acknowledgment of the crucial role women played in the rural economy (Grigg, 1987). Women in Agriculture (WaG) was set up in 1981. This was in response to the needs and interests of a new generation of rural women which the long established Country Women's Institute and 
Women's Division Federated Farmers no longer adequately represented (Grigg, 1987; Gray, 1987).

From the mid 1970's rural women began to take on a more equal role in farm planning and decision-making. With the rise of off-farm employment and a deepening rural downturn, women had less time for volunteer community activities and more paid jobs evolved from previously voluntary work. Women sustained rural communities and worked both on and off-farm (Grigg, 1987; Pomeroy et al., 1998).

While an upward trend in rural women standing for local government and statutory boards is evidenced from 1977, this was a decade later than this shift began for urban women. A summary of the 1983 local government elections show half of all county councils in New Zealand had no women members. A quarter had 1-19 per cent. In the same year, of 464 positions available on government appointed agricultural institutions, only seven were held by women. In 1984 four women MP's represented rural seats (Grigg, 1987; Pomeroy et al, 1998).

\subsection{PRE COOPERATIVE PERIOD}

\section{Alternative Lifestyle Communities}

Inward migration of alternative lifestyle settlers to Colville began in 1970 . Between 1970 and 1981 nine groups of young people established alternative communities on blocks of regenerating bush and marginal hill country. These groups formed the nuclei around which a larger permanent and transient population developed.

By the time the cooperative was formed in 1978 the majority of the alternative lifestyle communities around Colville were in a growth phase. The cooperative membership was drawn from these communities. The type of economic activity on the alternative life style properties varied a great deal. Some were working dairy, beef or sheep farms, others were bush blocks focussed on 
subsistence food production and seasonal employment. Others hosted micro enterprises such as boot making, fashion design, sound recording, craft production, bee keeping, wooden water tank production, and wind and water turbine production. The new migrants provided a pool of contract labour and were employed in forestry, farm labouring, building, shearing, teaching and nursing.

The people who established these communities were predominantly middle class, urban and educated. They had entrepreneurial skills and established a number of small business ventures. They brought these skills into the Colville cooperative, together with the values and experience of living cooperatively.

\section{Local Government Planning}

The Thames Coromandel District Council (TCDC) was formed in 1976 from the amalgamation of three smaller territorial units. The new institution inherited three different district schemes and limited planning capacity. This created a planning environment with little capacity to respond to changing community needs. In 1977 the first District Scheme was put in place. The flexible, semi-statutory environment under this District Scheme failed to provide planning tools to coordinate and integrate development or respond to change (Bedogni, 1983).

Local district council planning processes at the time were rudimentary. It had been a common experience for people in Colville to experience difficulty in obtaining planning permission to develop communally owned land, or to install new technologies. Despite this environment, alternative lifestyle communities nevertheless helped pioneer renewable energy technology. This included early experiments with water turbines, small-scale wind generation and solar technology instrumental in developing these technologies in New Zealand (Jones \& Baker, 1975; Bedgoni, 1983). 


\section{Population Trends}

The TCDC area experienced substantial population growth between 1971 and 1981. The total population of the TCDC area in 1981 was 18,000 . Between 1971 and 1981 the rural population almost doubled (Figure1). The total rural Coromandel Peninsula population grew by 4,752 (68.2 per cent) between 1976 and 1981. This compares to a national rural population growth of $2.4 \mathrm{per}$ cent over the same period. Much of the rural growth was a result of inward migration to the northern peninsula and rural hinterland around the towns of Coromandel and Whitianga. ${ }^{13}$ The growth was driven by the coastal environment, accessibility to Hamilton and Auckland and the availability of coastal land for development.

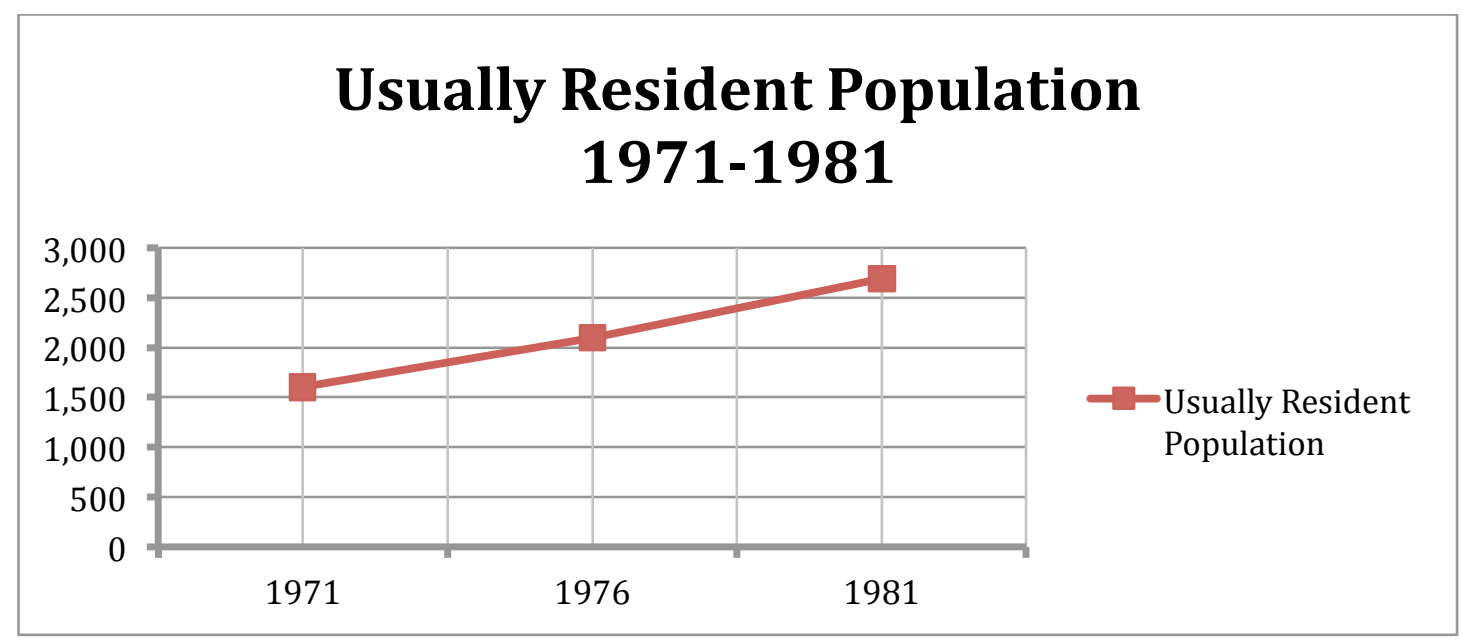

Figure 1: Usually Resident population. Remainder Coromandel Division CAU 1971- 1981 (TCDC, 2010).

The settlements of Colville, Port Charles and Kuaotuna experienced substantial population increase in the 1970's. While the total number of people was lower than other areas, proportionally the increase was significant. Alternative life style development was strongly associated with this population increase (Bedogni, 1983).

Inward migration had been dominated by two age groups: those aged 25-44 years with dependent children, and those aged 55 to 69 years (retirement

\footnotetext{
${ }^{13}$ Rural Census Area Unit 'Remainder Coromandel Division'.
} 
migration). Women with children dominated in the 25 to 44 year old group. Males dominated in the retirement migrant group. The inward migration was characterised by a high percentage of dependants and a disproportionally smaller number of working age/work available adults.

\section{Education}

For most of its history the Colville Primary School roll had been between 25 and 40 pupils. During the 1960's the roll declined and by 1975 there were only 14 pupils. The population then grew rapidly and by 1979 there were 32 pupils. There was another sudden increase in 1980, reflecting the inward migration of families with school age children into alternative life style settlements. Colville Primary School experienced a 142.9 per cent growth in pupil numbers between 1971 and 1980. It exceeded the prescribed threshold roll of 50 pupils well before the Hamilton Education Board provided a relocatable third classroom (Colville Historical Committee, 1990; Bedogni, 1983).

The nearest secondary school to Colville is in Coromandel town. In response to community pressure the Hamilton Education Board developed the Coromandel School into an Area High School in 1976, thereby giving parents more choice of secondary education for their children. Parents became less inclined to send children to boarding school as the subject choice, staffing and facilities were better in a designated Area School. (Bedogni, 1983).

\subsection{FOUNDATION PERIOD}

\section{Social Services}

Gray (1987) criticised the definition of essential services of the 1984 Ministerial Task Force on Social Welfare ${ }^{14}$. She argued communication services - roads, transport, radio, TV, newspapers and telephones - were

\footnotetext{
${ }^{14}$ Ministerial Task Force on Social Welfare Services. 1986: 4.
} 
essential rural services. Gray blamed urban generated policies and planning for the high mobility of people within, and in and out of, rural areas and a downward spiral of declining population and associated loss of social, education and health services.

This was consistent with a survey of Colville community needs by Scotts et al., (1987). This study found that access to health services at that time was adequate for less than half the 103 survey respondents. A quarter of all respondents were single parents and another quarter looking for employment. Almost half were trying to create their own employment. A high need for youth and adult education services was reported.

Bedogni (1983) argued institutional responses to population growth could have been expected to focus on providing services to the coastal settlements and hinterland and the two dominant migrant groups - women and children, and retirees. However new services had not been established in those areas nor targeted to those groups of people.

\section{Education - From Agriculture Day to Pet Day}

At its height in the mid 1980's the Colville School had around 70 pupils. An old prefabricated building was added in order to cope with the higher pupil numbers. New school bus routes were added to collect children from remote alternative lifestyle settlements (Colville Historical Committee, 1990; Bedogni, 1983).

The Hamilton Education Board response to communities of alternative lifestyle development was based on a stereotype of these as transient populations (Bedogni, 1983). The consequence was the senior class at Colville School was taught in the corridor of the old two-room school building for some years. In 1985 the Colville School was finally refurbished and modernised. Basic facilities such as a sickbay, office, staffroom, toilet block, and pool changing sheds were provided. In 1989 a third teacher was appointed and the first Board of Trustees elected. 
The school's annual Agriculture Day was replaced by Calf Club and then by Pet Day. This allowed for pets other than farm animals to be displayed and reflected the changes in the community. The majority of pupils at that time were no longer from farming families. The Christmas Tree Night traditionally organised by the Colville Women's Division Federated Farmers was replaced by the school's own break-up and presentation night and this tradition persists to the present day.

\section{Health Services}

Health services were stretched by the fast rate of population growth. In 1981 the Department of Health's Equitable Distribution of Finance in Hospital Board's Advisory Committee identified Thames Hospital Board as significantly underfunded. ${ }^{15}$ Increased funding for specialist health services was made available, but the services were established in Thames, despite the population growth being primarily rural and in the northern Peninsula. As a result people in Colville had limited access to health services, more so because GP services were less developed at that time (Bedgoni, 1983). Despite community pressure the maternity service at Coromandel Hospital was discontinued. The hospital remained open long after most small hospitals in New Zealand closed and in latter years was a frail aged care facility.

\section{Infrastructure}

Gray's perspective on essential rural services was true of Colville. Electricity first reached Colville in 1961 and not reticulated further north until the 1980's. Power outages were common. There were a limited number of telephone lines and few community facilities. At the time the cooperative was established the road south to Coromandel was unsealed, in poor condition and subject to frequent slips and closures. The nearest doctor was 30 kilometres away in Coromandel. In 1990 the road between Coromandel and

\footnotetext{
${ }^{15}$ The Equitable Distribution of Finance in Hospital Board's Advisory Committee on Hospital Board Funding. Department of Health, 1981.
} 
Colville was finally sealed and the trip that had taken 40 minutes in the 1980's, today takes only 20 minutes (Colville Historical Committee, 1990).

\section{Local Government Planning}

The first regional council (Thames Valley Regional Council) was established in 1980. It adopted a very basic zoning system and had limited planning capacity. The council failed to recognise the size of rural population growth, the changing demographics and demand for a wider range of land uses as rural landowners adapted to the changing rural economy. Most of the Colville area was zoned Rural A or coastal conservation zone. This recognised traditional agricultural and forestry, but failed to respond to demand from new settlers and existing farmers for other land use options. Alternative lifestyle properties were particularly affected. Residents had great difficulty obtaining planning permission for co-housing and other community enterprises. The cooperative for example was refused permission to install an environmentally friendly sewerage system which councils in other parts of New Zealand permitted at that time.

By 1981 the total population was more than the regional council projection for 1995. The 1971-1990 District Scheme failed to recognise the non-traditional pattern of rural growth, particularly around the northern coastal townships. Rural growth occurred despite statutory planning, rather than within any responsive framework, and there was inadequate management of development (Bedogni, 1983).

The New Zealand Post and Post Bank withdrew services from Colville in 1989. A voluntary Postal Trust continued a postal service but the nearest bank was 27 kilometres away in Coromandel. A Volunteer Fire Brigade was established in 1984 after a series of house and scrub fires (Colville Historical Committee, 1990). 


\section{Employment}

In response to a poor economic environment and persistent high unemployment in the 1980's the government developed programmes to promote employment, enterprise and community development. These programmes helped spawn a new wave of cooperatives in New Zealand. ${ }^{16}$ An evaluation of the Alternative Employment Programme in 1991 concluded demand for the programmes had increased as the economic situation worsened. Following the Enterprise Assistance Review (1991), and the July 1991 Budget, all community employment activities transferred to the Department of Labour. The range of programmes was reduced and government withdrew from support for work cooperatives. The national worker cooperative movement eventually collapsed.

\subsection{TRANSITION PERIOD}

\section{Population Change}

Between 1996 and 2001 the population of the Colville area was stable. Over the next five years however the population declined markedly, falling by almost 50 per cent from 621 residents, to 306 residents (Figure 2 ). ${ }^{17}$

\footnotetext{
${ }^{16}$ Programmes include the Community Employment Development Unit; Local Employment and Enterprise Development Scheme; New Zealand Employment Service wage subsidies; Department of Internal Affairs Alternative Employment Programme, Work Development Scheme and Small Cooperative Enterprises Scheme.

${ }^{17}$ Bearing in mind the 2001 and 2006 census area units and mesh blocks areas are slightly different, as described in Chapter 3.
} 


\section{Usually Resident Population \\ 1991-2001}

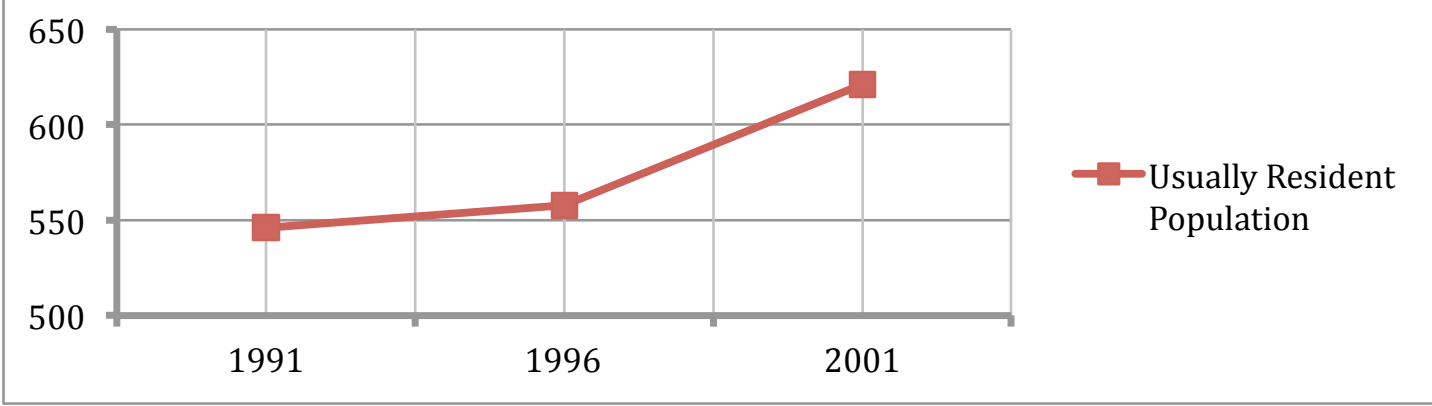

Figure 2: Usually Resident Population. Te Rerenga CAU 1991-2001 (Bedgoni, 1983; TCDC, 2010)

\section{Employment}

Between 1996 and 2001 multiple job holding increased in highly rural and remote rural areas of New Zealand, while it fell in urban areas (Taylor et al., 2007). These trends were also seen in Colville. For the first time women from farming families sought employment at the cooperative's store and farmers branched out into tourism through farm stays and campgrounds.

From 1991, cuts to benefit levels drove urban-rural migration as beneficiaries relocated to provincial and rural areas to cut living costs. Women with dependent children made up a significant proportion of new settlers in the northern Coromandel. However a national Remote Area policy also restricted beneficiaries from moving to areas with limited employment opportunities. The policy was applied in Colville, effectively making it a 'no-go' zone for the unemployment benefit (Morrison \& Waldegrave, 2002; Jobs Letter, 2003; Hansaard, 2003; Bradford, 2004). One effect of the Remote Area policy was to increase the supply of labour available in Colville. It became impossible to move to Colville and onto an unemployment benefit, and difficult for people already living there to move on and off the unemployment benefit to fit around seasonal work. 


\section{Social Services}

New social services appeared in Colville in 1996. Previously, local organisations including Women's Division Federated Farmers, Colville Cooperative, Colville Youth Club and St John Ambulance volunteers provided community support. In response to increased community needs a social service centre was established in 1996 under the umbrella of the cooperative. The Colville Social Services Collective provided information, advice, referrals, adult education, youth work, health and budget clinics, public computer access and photocopying. It became a charitable trust and moved into its own premises in 1999 and is still providing those services in 2010.

Despite Colville's distance from primary and secondary medical services the Waikato District Health Board at that time put only one dollar per head of population into public health transport (Kristensen, 2009). ${ }^{18}$ Access to primary health services improved over time with better roads, a local social services centre and the establishment of a small general medical practice in the village of Colville. However specialist services remained a considerable distance away in Thames or Hamilton.

\section{Role of Women}

The Colville Women's Division of Federated Farmers changed its name to Rural Women in 1998. The Colville Branch had a membership of 30 during the 1980's. By 1990 the changes in farming and the rural economy resulted in fewer farm families and the membership fell to 13 . In 2010 there were just seven members.

Within the alternative lifestyle community there were women's health groups and workshops on health and personal development. A contingent of Colville women attended the first National Women's Convention, and each year

\footnotetext{
${ }^{18}$ Waikato Regional Land Transport Strategy Review of Access and Mobility and Public Health Outcomes, 1999. Review identified one community transport provider in Colville - a gifted ambulance.
} 
International Women's Day was celebrated with a community event. The 1983 celebration of International Women's Year included a march down the main street in Colville by a group of 30-40 men and women carrying a banner proclaiming "You Can't Cuddle Children with Nuclear Arms".

\subsection{SECOND GENERATION}

\section{Population}

Between 2001 and 2006 there was a mass exodus of people from Colville. Almost half of the population left over that relatively short period. As noted previously, the population had been stable until 2001 (Figure 2). By 2006 the population was 306 people and half of all dwellings were unoccupied ${ }^{19}$. There was a high rate of resident churn - 58 per cent of people had lived in their current home for less than 5 years ${ }^{20}$ (TCDC, 2010).

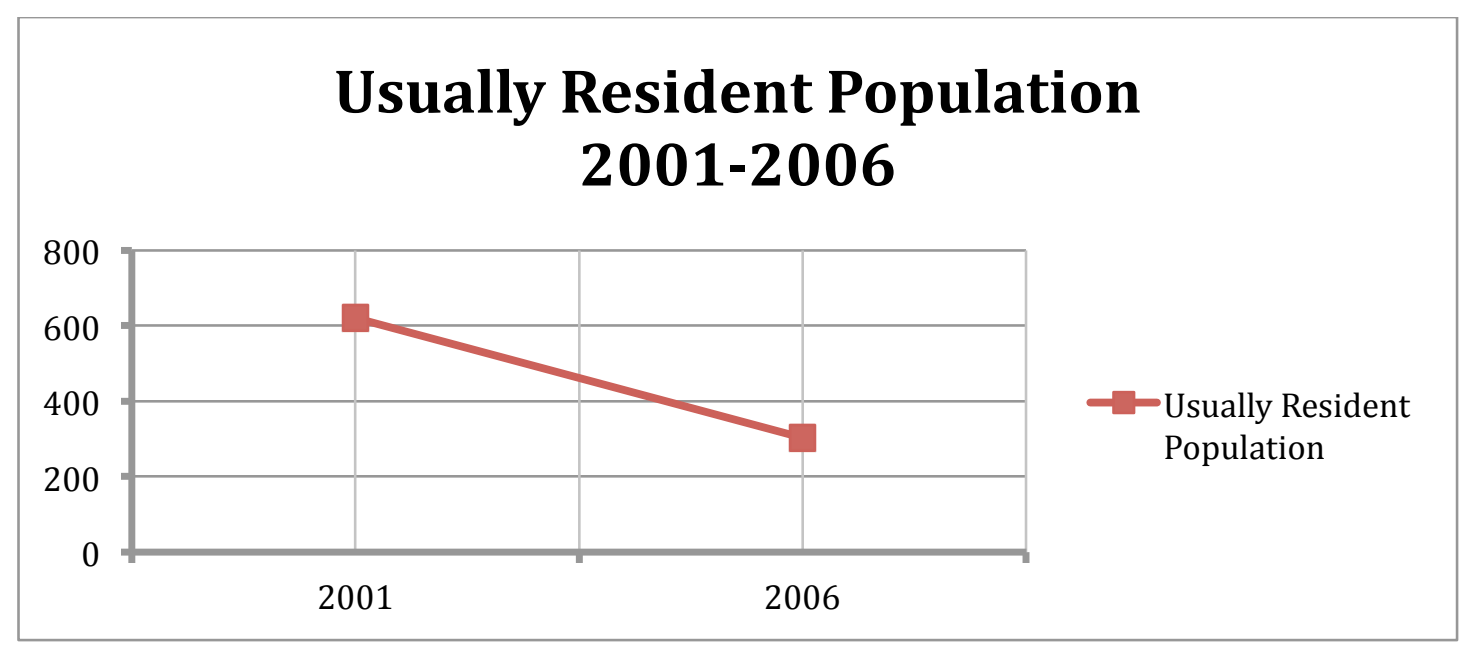

Figure 2: Usually Resident Population. Te Rerenga CAU 2001-2006 (TCDC, 2010).

The loss of population and increased residential transience had a significant effect on the pool of volunteers available to maintain community facilities, the

\footnotetext{
${ }^{19}$ This number is an approximation and varies probably by + or $-20-30$ people because of changes to mesh blocks between census.

${ }^{20}$ Data from some mesh blocks is withheld by Statistics NZ in order to protect identity of data in mesh blocks with a very small number of residents.
} 
viability of the school and pre-school, and pool of labour available to the cooperative. It also reduced the number of store customers.

Colville in 2006 was a poor community. Although the resident income and employment data is not entirely complete, data from four of the five 2006 census mesh blocks provides some insight. Median income was $\$ 21,900$. Thirty-six people received income from a government benefit. These included sickness, superannuation, domestic purposes and invalid benefits, student allowances and payments from work accident insurers. Of t84 households, just over half had incomes of less than $\$ 50,000$ per annum. Of 306 residents recorded on census night, 66 (21.5\%) were either dependent children or over the age of 65 years.

\section{Tourism}

The Coromandel Peninsula experiences an extreme annual population peak over Christmas and New Year. The peak population day in 2007/2008 was over five times the usual population (TCDC, 2008). Colville typically experiences a 12 day peak period between Boxing Day and 6 January. An additional 1,700 - 3,200 people need petrol and food supplies, putting considerable pressure on the store but also providing casual jobs. ${ }^{21}$ Up to 1,700 more vehicles use the narrow unsealed roads. Each year between January and March there are also more visitors, but at a lower volume (TCDC, 2008). Like most small businesses on the Coromandel the variations in consumer demand cause by tourism exert pressure on stock, cash flow, staffing and facilities (Dudding \& Ryan, 1999).

\section{Employment}

The annual influx of tourists and absentee homeowners returning for summer provided additional employment at the store and café over the summer months, but far less winter and off peak employment. Many residents still move between part-time employment and some form of government benefit.

\footnotetext{
${ }^{21}$ TCDC Peak Population Survey 2007/2008. Also 2003/04 peak population study and 2005/06 update and similar studies carried out in 1995/96, 1996/97 and 1997/98.
} 
Census data from 2006 show residents in fulltime employment were primarily employed in farming, fishing and related trades. There were significantly fewer professionals than in the rest of the TCDC area. ${ }^{22}$

\section{Education}

Throughout the history of the cooperative the Colville Primary was a full primary school (Year 1-8). It currently has a relatively low Level 4 decile rating. In 2010 the school had 28 pupils (Coromandel Post, 2010).

\subsection{CONCLUSIONS}

The Colville community in 2010 was very different from the community from which the cooperative emerged in 1978. Like most New Zealand rural communities Colville has experienced cyclical economic upswings and downturns. Over the lifetime of the cooperative the community has experienced both population and economic growth, and rapid depopulation and economic decline. High inward migration by young, middle class settlers in the 1970's and 1980's drove two decades of social, economic and housing growth. The cooperative flourished during this time. A dramatic loss of population between 2001 and 2006 saw more than half of the homes formerly occupied year-round converted into holiday or rental homes. About half of the former permanent residents left. The remaining resident population in 2010 was generally older, sicker and more dependant.

22006 census data provided by TCDC, 2010. 


\section{CHAPTER 5}

\section{TRACING ORGANISATIONAL CHANGE IN THE COLVILLE COOPERATIVE}

\subsection{INTRODUCTION}

This chapter traces the development of the cooperative and the store from 1978 to 2010 through the organisation's written documents. These reveal a rich history of the organisation and the people involved in it.

The first section of the chapter identifies the key sources of data from which the chapter content was generated, and notes issues of completeness or verifiability. The balance of the chapter organises data under the four time periods adopted for this study, and within these, by subject. The time periods are Pre Cooperative period (pre September 1978); Foundation period (1979 - 1989); Transition period (1990 - 1999) and Second Generation period (2000 - 2010). The subjects are Membership, Organisational Structure, Governance, Contribution to Local Economic Development, Financial Performance, and Protecting Environment and Sustaining Community.

The Pre Cooperative and Foundation periods reveal a struggle to create a viable business and a community cooperative, and the functional relationship between these two factors. Group entrepreneurship and strong leadership were features of this period. The business was profitable but marginal, and required vigilant financial management.

The Transition period heralded a change in leadership and management. The first pioneer rush of creativity was over and the growth of the cooperative and the store slowed. The store remained financially viable and the cooperative, although changing, was strong and functional.

The Second Generation brought significant change in the community, leadership of the cooperative and management of the store. The store 
floundered financially and the cooperative became somewhat dislocated from its community and members. A low point in democracy and financial performance was reached. This crisis drove a member rebellion. At the end of this period tentative new growth of a more functional cooperative and business were observed.

\subsection{THE REVIEW OF DOCUMENTS}

The early history of the organisation is preserved in a small number of legal documents: property titles, lease and purchase agreements, letters between lawyers and clients, documents of incorporation, and applications for loans or grants. A large volume of governance and management information was found in minutes of meetings, personal letters, newsletters, reports on loans and grants, annual and periodic financial records and formal and informal file notes. A number of documents were undated. These could only be placed in time through cross-referencing with other documents, or information provided by interview respondents. Despite the lack of an organised filing system a remarkably intact and rich set of historical written records was identified.

The documents were found in old cardboard boxes, exercise books, ring binders, paper folders, envelopes, loose piles of hand-written letters and accounts and bound documents. Archival materials were stored in filing cabinets, ceiling spaces, underneath desks and unused shelves, in unmarked boxes and in a warehouse storage space. Financial records were in a more readily identifiable format, particularly after these were computerised in 1984 .

Identifying the structure of the organisation at different periods of its history proved challenging. Firstly, the records were in no logical order and the time line was pieced together from disparate notes, minutes, letters and legal documents. Secondly, the first few years of the cooperative's history involved a series of informal arrangements obliquely referred to in letters or undated notes. Thirdly, the organisation comprises two closely entwined legal entities, an Industrial and Provident Society (the cooperative) and a Limited Liability Company (the store) wholly owned by the cooperative. Lastly and importantly, 
the cooperative had a structure bearing little resemblance to traditional organisational forms.

\subsection{PRE COOPERATIVE PERIOD (1977-1978)}

\section{Membership}

In August 1978 three individuals established the Mapua Trust (also known as the Mapua Group) to purchase the store and hold it in trust until it could be handed over to a cooperative..$^{23}$ This was part of a vision to create "an alternative economic community" in Colville. ${ }^{24}$ The founding role of these individuals is consistent with the recollections of Pre Cooperative interview respondents. The resources of each trustee would contribute to the independent economic community; one trustee would contribute $\$ 60,000$, the other two would contribute business and accountancy skills. The trustee contributing the finance would own the land and buildings and rent these to the cooperative, which had the right to future purchase. The store business would be gifted to the cooperative; profits from the store would flow to a trust or cooperative and be used for other community development projects. ${ }^{25}$

\section{Organisational Structure}

Ownership of the Colville General Store (1974) Ltd, and the land, buildings, and stock transferred to the three trustees on September $10,1978 .^{26}$ The business was incorporated as Delphin Traders Ltd $^{27}$ on 29 September 1978, with the three trustees as company directors and shareholders. ${ }^{28} \mathrm{~A}$ nominal

\footnotetext{
${ }^{23}$ Statement by Andy (Phillip) Anderson, page 13, Application to Cooperative Enterprise Loan Trust (CELT), 24/2/1986.

${ }^{24}$ Submission by Colville Cooperative Society (CCS) to the Department of Internal Affairs (DIA) for assistance under the SCOPE scheme dated 8/3/1982.

${ }^{25}$ Letter from Peter Cumming to Philip Anderson dated 21 August 1982.

${ }^{26}$ Certificate of Title Vol 1026, folio 123. Transfer to P. Cumming, P. Anderson and A McKee.

${ }^{27}$ Agreement for Sale and Purchase of Shares between Philip Anderson, Peter Cumming and Alastair McKee and CCS, $31 / 10 / 1982$ to sell the shares in Delphin Traders to the Cooperative for $\$ 19,900$ and to repay to Alastair McKee a loan of $\$ 6,000$.

${ }^{28}$ Letter from Desmond Piggin to Purnell, Jenkinson, Tegg and Roscoe (Solicitors) 9/11/1981 confirming Cummings, Anderson and McKee as directors of Delphin Traders Ltd and owners of the land and buildings.
} 
fourth shareholder held one share. ${ }^{29}$ Delphin Traders Ltd would act as a holding entity until a cooperative could be established.

\section{Governance}

Formal governance was through the directors of Delphin Traders Ltd until the cooperative was incorporated in 1980. Functionally there was a worker cooperative managing the store and moving the group toward establishing a cooperative legal entity. The only working director of Delphin Traders Ltd exercised formal authority until the legal structure, rules and contracts were in place. On a day-to-day basis this director was treated as an equal member of the worker cooperative. ${ }^{30}$

A dispute between the directors arose in April 1979. The financing director disputed gifting the store to the cooperative and the sale the land and buildings at a previously agreed price. This director wanted his capital returned, plus interest. The cooperative was asked to buy the store and property at current market value and pay market interest rates on the finance ${ }^{31}$. The cooperative argued the store was run down and barely functional when purchased. Any increase in market value had been created through workers accepting below market wages, volunteer labour, gifted materials and the skills of cooperative members. The cooperative argued it did not need to purchase the business as this was already gifted. The dispute was protracted and bitter. After several years of negotiation the cooperative agreed to buy the business, land and buildings at the original purchase price. This repaid the start-up finance in full.

\section{Contribution to Local Economy}

Colville was a low income community so finding start-up finance was a key element in securing a commercial enterprise that couldn't rely on cooperative

\footnotetext{
${ }^{29}$ Articles of Association of Delphin Traders Ltd. Register of Commercial Affairs, Auckland, 28 September 1978. Lists share capital of $\$ 20,000$ in $\$ 1$ shares and Phoebe MacDiarmid holding 1 share.

${ }^{30}$ Personal statement from Andy (Phillip) Anderson 24/2/1986 p 13-16 of loan docs for CELT.

${ }^{31}$ Market interest rates were 18-23 percent.
} 
member's capital investment. The Mapua trustees had thought it important the organisation be free of the cost and control of bank finance in order to create an economically independent community.

Because of the dispute the cooperative instead needed to find $\$ 60,000$ in a difficult credit market, ${ }^{32}$ a beginning that undermined the creation the vision of an alternative local economy. ${ }^{33} \mathrm{Re}$ - financing came eventually from two sources - a $\$ 15,000$ interest-free loan from the Department of internal Affairs (DIA) in 1982, and $\$ 29,000$ from the Cooperative Enterprise Loan Trust (CELT) in 1986 at 18 per cent interest. The balance of $\$ 20,000$ came from the worker cooperative through gifted wages.

The importance of start-up finance cannot be over-stated. The cooperative, although a community-owned project, was dependent on a philanthropic individual to secure the asset through which it could realise its aims. The vision of an economically independent village which met community needs through small cooperative enterprises drove the initial philanthropic impulse. The worker's contribution was critical in later repaying loans.

\subsection{FOUNDATION PERIOD (1978-1989)}

\section{Membership}

There were 12 founding members of the cooperative which registered as an Industrial and Provident Society (IPS) in July $1980^{34}$. The occupation of founding members includes fisherman, farrier, store worker, spinner and farmer. These do not sound like middle class individuals. However half the founding members held university degrees. Several others had professional

\footnotetext{
${ }^{32}$ Correspondence from Purnell, Jenkinson, Tegg and Roscoe (Solicitors) and the cooperative, to Desmond Piggin (on behalf of Alastair McKee) and Purnell, Jenkinson, Tegg and Roscoe (on behalf of the Cooperative), 9 November 1981; Letter from Peter Cumming (Director, Delphin Traders) to Phillip Anderson (Director, Delphin Traders), 21/8/1982.

${ }^{33}$ Personal statement from Andy (Phillip) Anderson accompanying application by the cooperative to CELT for loan to refinance purchase, March 1986: 13-15; Letter from Peter Cumming to Philip Anderson, 21/8/1982.

${ }^{34}$ New Zealand legislation requires a minimum of 12 members to register an Industrial and Provident Society (IPS).
} 
training, including a nurse, journalist, two teachers and an accountant. This suggested the founding members were probably not working class as the listed occupations imply. ${ }^{35}$ Surviving Registers of Members from 1980 to 1989 show that in the first nine years the membership of the cooperative trebled, from 29 members in 1981 to 94 members in 1989 (Table 4). This represented the cooperative's fastest membership growth period. ${ }^{36}$

\begin{tabular}{|c|c|}
\hline & Number of members \\
\hline 1980 & 13 \\
\hline 1981 & 29 \\
\hline 1982 & 48 \\
\hline 1983 & 60 \\
\hline 1984 & 67 \\
\hline 1985 & 83 \\
\hline 1986 & $88(68)$ \\
\hline 1987 & 89 \\
\hline 1988 & 90 \\
\hline 1989 & 94 \\
\hline
\end{tabular}

Table 4: Number of Members 1980-1989. Colville Cooperative Society.

Membership categories, rights and shareholding were established at the start of the Foundation period. The criteria for membership was six months residence in the former Colville Riding of the Thames Coromandel District Council, application in writing, payment of a nominal sum and approval of the application at an Annual General Meeting (AGM). ${ }^{37}$ Under certain conditions non-residents could acquire or retain membership. Members could attend any meeting and view all records. Members appointed a Secretary and elected a Committee of Management (the committee) at each AGM. The committee had the power to invest profits in any activity permitted by the Industrial and Provident Society Act 1908.

Each member held one share. The share was not transferable or redeemable, and forfeit on withdrawal from the Society or on death. Profits could not be distributed to share holders. Every member had one vote on each matter. Where members held divergent views, the issue was determined by

\footnotetext{
${ }^{35}$ Application for Incorporation of CCS as an IPS.

${ }^{36}$ For 1986 there are two slightly different Register's of Members.

${ }^{37}$ Rules of CCS (27/2/1996 version); Register of Members 1980 -1999 shows amount and date of payment for each member.
} 
consensus. On wind-up of the cooperative any surplus assets after debts were repaid must be distributed to organisation(s) with similar objectives. ${ }^{38}$

The cooperative had both worker and consumer members ${ }^{39}$. This made it an early form of multi-stakeholder cooperative as described by Zeuli (2002), Zeuli et al (2004), Evans \& Meade (2005), Logue \& Yates (2005) and Girard (2009). In contrast to other cooperatives, members of the Colville Cooperative did not invest or financially benefit from their membership.

Worker members were described in 1986 as "local people who needed work, want to work collectively and who support the values and see how the cooperative benefits the community" 40 . The same document referred to "a separate worker cooperative operating within the wider cooperative" ${ }^{41}$. This was consistent with findings from the interviews that the Colville Restaurant (the café) and store were initially run as worker cooperatives.

\section{Organisational Structure}

There was a protracted process to establish an organisational structure for the cooperative in the context of the dispute between the three directors of Delphin Traders. The cooperative registered in 1980 holds all the shares in Colville General Store Ltd which it purchased from Delphin Traders Ltd in 1982. The company name was changed to Colville General Store Ltd in $1987 .{ }^{42}$ The cooperative continued to lease the land and buildings until purchasing these in 1986. ${ }^{43}$ The cooperative elected a small committee of management to oversee the cooperative as a whole and this committee reports annually to members at the AGM (Figure 4).

\footnotetext{
${ }^{38}$ Rules 4-9, 12 and 13 of CCS (27/2/1996 version

${ }^{39}$ Circular to CELT Loan Committee and Board Members, 12/3/1986. Letter from Bevan Fitzsimons to Auckland Core Group, 19/3/1986.

${ }^{40}$ Circular to CELT Loan Committee and Board Members, 12/3/1986.

${ }^{41}$ Letter from Bevan Fitzsimons to CELT Auckland Core Group, 19/3/1986.

${ }^{42}$ New Zealand Companies Office, Certificate of Incorporation, Colville General Store Ltd \#104047.

${ }^{43}$ Circular to CELT Loan Committee and Board Members from Auckland Core Group dated 12/3/1986. Report on the CCS, Bevan Fitzsimons. 19/3/1986.
} 


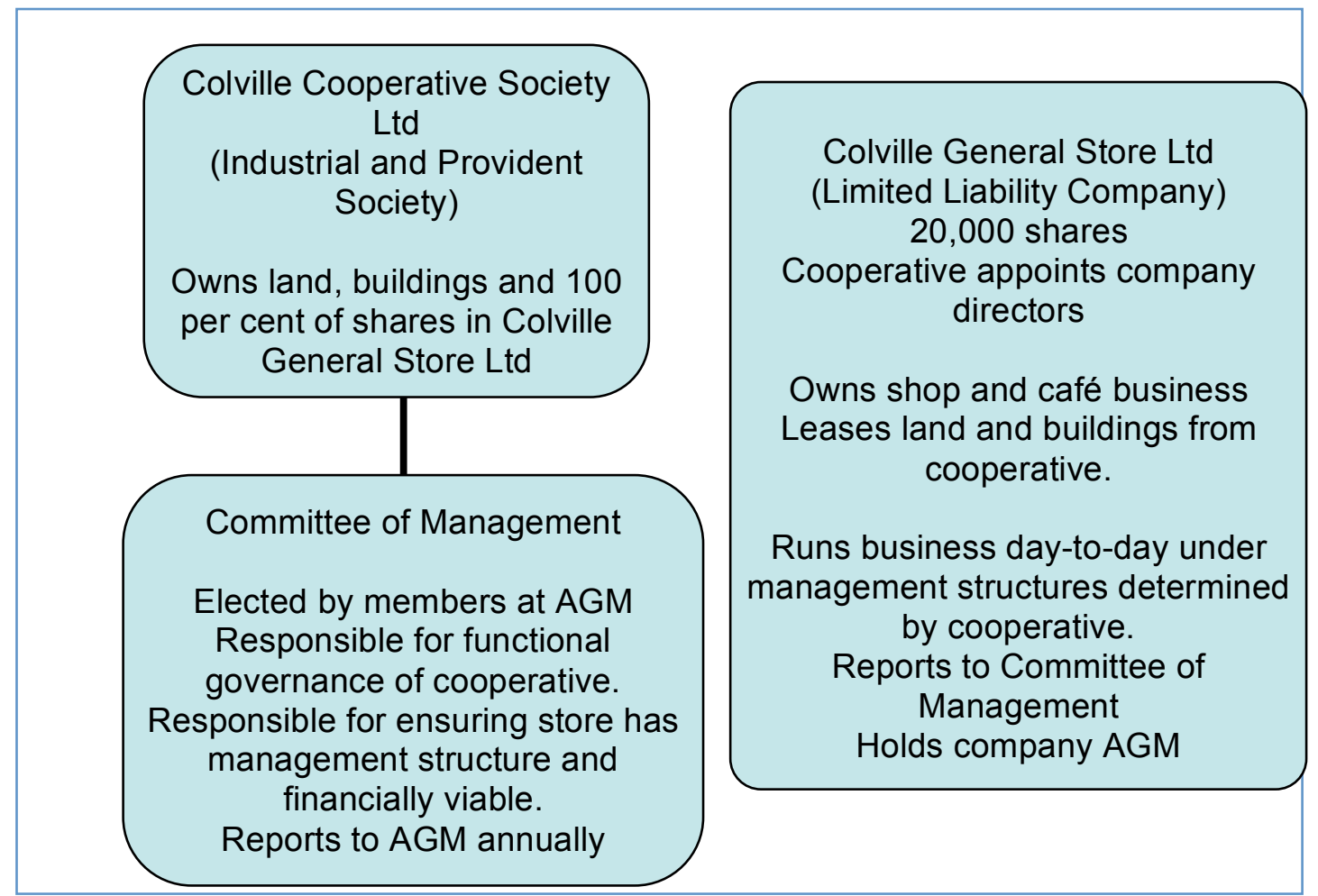

Figure 4: Organisation Structure 1980-2010. Colville Cooperative Society

When the cooperative was registered the worker cooperative running the store and café continued to manage these with a high degree of autonomy. ${ }^{44}$ The worker cooperative reported to the committee regularly, and to the whole cooperative annually. A flat management, flat wage structure was in place until 1988. In an unusual arrangement individuals could occupy governance, management and employee roles simultaneously. ${ }^{45}$ This structure persists throughout the history of the organisation.

In response to a financial crisis in 1987 the committee took over direct management of the business. ${ }^{46}$ Control passed back to the worker group in May 1988, but under a two-tier organisational structure designed by the workers. Coordinators were made responsible for store buying and stock

\footnotetext{
${ }^{44}$ Application for Incorporation of CCS Ltd as Industrial and Provident Society

${ }^{45}$ The committee consisted of 50:50 worker and consumer members. Workers could sit on the committee to whom their functional manager reported and also be in a coordination/ manager role. The committee could make day-to-day business decisions but had no authority to instruct workers to implement these until it managed workers directly.

${ }^{46}$ Notice to all Cooperative Workers and Members. Results of Committee Meeting held 11/2/1978 re Shop Management.
} 
control. A 1989 review of the structure found it working well. ${ }^{47}$ This is consistent with findings from Foundation and Transition period interview respondents, who also report this structure worked well.

\section{Governance}

The store is technically governed by company directors, who in turn answer to the committee and members of the cooperative (Figure 5). However, for much of its history, the store has been governed and often directly or indirectly managed by the cooperative's committee of management.

Governance was characterised by direct democracy. Minutes from AGM's and committee meetings support the view of interview respondents that there was strong group and individual leadership at this time. Strong community support was evidenced by a growth in membership. The cooperative was active in community and environmental projects. A lack of recorded conflict suggests goals and values were widely shared amongst the membership and governance arrangement supported.

Decision-making within the cooperative was by consensus. ${ }^{48}$ This method was used at AGM's, committee and worker meetings. The cooperative was described in 1986 as "a strong group with democratic and cooperative meeting processes, good facilitation skills and community spirit". ${ }^{49}$ A 1983 Alteration to the Rules of the Cooperative clarified how notice of meetings was given to members, and special meetings convened. ${ }^{50} \mathrm{~A}$ further Rules change prevented members from financially benefitting from sale or wind up

\footnotetext{
${ }^{47}$ The History of Coordinators. M Johnson 1989:3. Quotes Minute of Cooperative's 1989 AGM

${ }^{48}$ Circular to CELT Loan Committee and Board Members from Auckland Core Group. Report on the CCS, Bevan Fitzsimons. 12/3/1986; Personal statements from Lonsdale Wiren 25/2/1986, Wayne Todd, u/d and Peter Wasley 16/2/1986, accompanying CCS loan application to CELT p 20.

${ }^{49}$ Circular to CELT Loan Committee and Board Members from Auckland Core Group. Report on the CCS, Bevan Fitzsimons. 12/3/1986

${ }^{50}$ Alteration to Rules of CCS Ltd. Registrar of Industrial and Provident Societies, Auckland, 20/10/1983. 44. Circular to CELT Loan Committee and Board Members from Auckland Core Group. Report on the CCS, Bevan Fitzsimons. 12/3/1986

45. Minute of Extraordinary General Meeting of CCS, 14/10/1998.
} 
of the cooperative. Initially the committee had a strategic planning and policy role, and met quarterly. ${ }^{51}$

Cooperative

Members

Elected

Committee of

Management
Directors of

Colville General

Store Ltd ( elected

from Members )

Figure 5: Governance Structure 1980-2010. Colville Cooperative Society

\section{Contribution to Local Economy}

\section{Wages}

Records show the cooperative paid $\$ 692,621$ in wages to its employees between 1982 and 1989 (Table 6) ${ }^{52}$. There is no basis on which to estimate the first four years for which the data was missing. Other records show workers took very low hourly rates (\$ 2-5 per hour) in the first few years and gifted a portion of their wages to help the cooperative establish. Worker contributions were augmented by voluntary labour by other members.

\begin{tabular}{|c|l|c|c|}
\hline Year & $\begin{array}{l}\text { Wages } \\
\text { Paid }\end{array}$ & Year & Wages Paid \\
\hline 1982 & 22,615 & 1986 & 112,000 \\
\hline 1983 & 58,943 & 1987 & 119,565 \\
\hline 1984 & 69,882 & 1988 & 124,207 \\
\hline 1985 & 78,248 & 1989 & 107,161 \\
\hline
\end{tabular}

Table 6: Wages Paid 1982-1989. Colville General Store Ltd

\footnotetext{
${ }^{51}$ Sources: Annual Accounts Colville General Store Ltd; Annual Accounts Colville Cooperative Society; Labour Contract Wage Adjustment Rates 1982 - 1987; Working Paper for Wages Claim; Notes to Cash Flow Budgets 1986-1990 for Delphin Traders Ltd.
} 


\section{Employment}

In its first decade the cooperative each year provided 14 - 22 permanent parttime jobs, and 25+ summer jobs. Comparing this to a typical country store, the Cooperative Enterprise Loan Trust noted in 1986 report on the cooperative:

"Typically a country store was staffed by a couple employing family members and friends. Ownership usually changes every three or four years and the capital gain was removed from the rural area. The cooperative has created jobs were none existed... shorter working weeks had created six extra jobs". B. Fitzsimons (1986:3)

The Department of Internal Affairs loaned the cooperative $\$ 15,000$ on the basis of the employment created. ${ }^{53}$

\section{Financial Performance}

Over the Foundation period the cooperative grew quickly and repaid debt. The fledgling cooperative had taken over a "run-down and bankrupt" business and there were initial teething problems. ${ }^{54}$ The cooperative had not yet formally established and the worker cooperative lacked business knowledge. The new organisation began life owing $\$ 20,000$ for the purchase of stock and shortly afterward faced the need to raise $\$ 60,000$ to repay the original financier. 55

The cooperative requested secured loans and sponsorship from the community so the enterprise would still be financed cooperatively. ${ }^{56}$ Only three small loans of $\$ 2-5,000$ were offered, well short of the $\$ 62,000$

\footnotetext{
${ }^{53}$ Notes from Submission to DIA from CCS for assistance under the Small Cooperatives Enterprise Scheme (SCOPE), 1982; 1985.

54 "The credit squeeze hits" Cooperative Newsletter \#2, p 1-2, 1981.

${ }^{55}$ Report on CCS, Bevan Fitzsimons. 12/3/1986

${ }^{56}$ Committee of Management Action Group file note, undated. Presumed between1980 - 1982.
} 
required ${ }^{57}$. Bank interest rates were 23 per cent and beyond the cooperative's ability to service. ${ }^{58}$ The cooperative had to find other sources of money. In the end the money was raised through discounted or no interest loans and worker contributions. Loans of $\$ 15,000$ in 1982 , and $\$ 29,000$ in 1986 , were raised to refinance the purchase of the property and business. ${ }^{59}$ The cooperative contributed \$10,000 in 1982, and again in 1986, toward refinancing. In 1985 the cooperative lent the store $\$ 14,200$ after a year of poor financial results.

\section{Colville General Store Profit/Loss 1979-89}

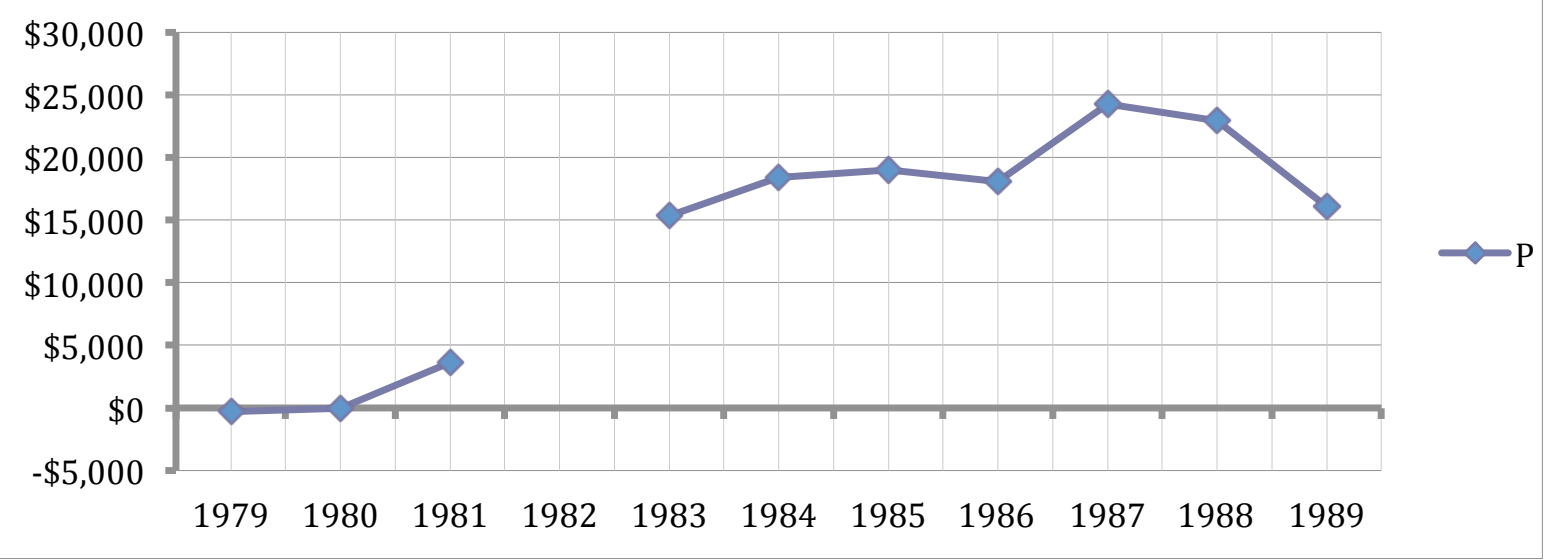

Figure 6: Annual Profit and Loss 1979-1989. Colville General Store

Based on the analysis of the Colville General Store Ltd Annual Accounts from 1979 to 1989 the organisation was buoyant and growing (Figure 6). Turnover of the store increased by approximately $\$ 100,000$ each year until 1986 , after which growth slowed. Turnover was just under $\$ 1$ million a year at the end of the Foundation period and profits were posted each year. The cooperative accumulated its own funds through s labour contact and rental income.

From 1983 to 1987 year-on-year increased sales, rising profit, stock and assets were reported. ${ }^{60}$ The growth was due to a rapidly increasing

\footnotetext{
${ }^{57}$ Cooperative Refinancing Plan, undated. Presumed to be $1980-1982$.

${ }^{58}$ Bank of New Zealand Thames interest rate, March 1986. Circular to CELT Loans Committee and Board Members from Auckland Core Group, 12/3/1986. p3

${ }^{59}$ Application to DIA for loan under SCOPE scheme for $\$ 15,000$; loan agreement between CCS and CELT in 1986 for $\$ 29,000$.

${ }^{60}$ Circular to CELT Loan Committee and Board Members from Auckland Core Group. Report on the CCS, Bevan Fitzsimons. 12/3/1986
} 
population and the store customer base. The alternative life style community and summer visitors were not dependent on farm incomes, which have fallen dramatically in the 1980's. But the store was dependent on good summer weather to bring holiday visitors. Approximately one third of total annual sales were made in January. Campers made up the major part of those sales. ${ }^{61} \mathrm{~A}$ wet summer translated into poor sales, fewer jobs and cash flow problems the following winter.

A cash flow crisis in 1981 revealed the vulnerability of an indebted marginal rural business. In response to poor national economic conditions the bank halved the store's overdraft facility. This had a significant impact. The overdraft was used to purchase the stock to meet peak summer visitor demand. To help manage cash flow store customers were asked to pay off $\$ 7,000$ in outstanding credit, and to use cash to purchase goods. ${ }^{62}$

In 1987 there were more difficulties. The committee described the store as in "a perilous state" and group decision-making processes "in a state of confusion". Financial performance had deteriorated. The committee believed workers lacked the skills to make necessary decisions for recovery. The committee took direct control of the store and restructured jobs to reduce costs. ${ }^{63}$ A two-tier structure was created and remained in place until 2004. In February 1988 a notice to customers highlighted $\$ 3,000$ permanently owing on weekly credit. The impact of the introduction of GST, a wet summer, theft, and loss of the local Post Office in 1989 all impacted on the viability of the store. The store was "holding its own, but tight" ${ }^{64}$

Data for the café was partial but its financial performance had clearly been variable. The café had periods of being leased out, and periods of being managed by the store. It had been leased for the first time in 1984/85 to reduce the cost of keeping it open. ${ }^{65}$ A loss was recorded for 1989 . Funding

\footnotetext{
${ }^{61}$ Store Profit and Loss Statements 2003 and 2004.

${ }^{62}$ The credit squeeze hits". Cooperative Newsletter, 1981:1-2

${ }^{63}$ Minutes of Committee meeting, 11/21987

${ }^{64}$ Committee report to 1989 AGM of CCS.

${ }^{65}$ Minute of AGM of CCS 23/10/1984.
} 
necessary café maintenance and repairs was an issue. ${ }^{66}$ Interview respondents referenced the importance of the café as a community meeting place. The cooperative was under pressure to keep it open for its social significance, despite the poor financial performance.

\section{Sustaining the Environment and Promoting Community}

\section{Environment}

The cooperative sought to address environmental concerns in a wide range of ways. It had done that through monitoring and minimising its own waste and energy use; supporting environmental campaigns and stocking environmentally safe products. The employment of an environment worker to research the environmental, animal and human safety of products sold in the store, and eliminate those considered most harmful, was important in achieving environmental aims. It helped ensure the store stocked organic, healthy and environmentally safe products, and goods were sold without packaging. The environment worker was important in the quality control of the store 'brand', the brand being healthy and environmentally safe products. ${ }^{67}$ Suppliers were also encouraged to reduce packaging.

The store displayed information and petitions on environmental issues and sold conservation, environmental and human rights fundraising products. It provided rubbish recycling bins and made submissions to local government on planning and resource issues, and to central government on food and product safety. The cooperative objected to and made submissions about, any loss of community services. ${ }^{68}$

\footnotetext{
${ }^{66}$ Committee report to 1989 AGM of CCS. "Maintenance issues in restaurant".

${ }^{67}$ Report of Environment Worker to Committee 6/9/2001.

${ }^{68}$ Letter to Ministry of Agriculture and Fisheries Environmental Resource Centre re Water Quality and Shellfish from CCS. Minute of Committee meeting, 1/10/1991; letter from Department of Conservation, Hamilton Regional Office re input to DOC Management Planning for Coromandel Peninsula, 2/5/1989; letter from Neil Henderson, Consulting Engineer to GS re sewerage system upgrade, 27/10/1989; letter to Phillip Woollaston, Associate Minister for Environment from CCS requesting information about aerosol sprays that don't use chlorofluocarbons as propellant 11/10/1988; letter from W. Kedzlie, Deputy General Manager, TCDC from CCS re objection to total ban on roadside camping; letter from CCS to Chief Engineer, TCDC supporting Council expenditure of rates on environmental planning;
} 


\section{Community support}

Evidence of the cooperative's involvement in community activities was scattered through old correspondence, loan applications, newsletters and notices and governance records. It was clear the cooperative, often through its proxy the store, was actively involved in supporting individuals with needs, and with groups wanting to establish community services. It had done that through both direct and indirect support.

During the Foundation period the cooperative responded to requests from the community to provide work experience for young people. In 1985 a Youth Training Scheme was established at the store. Respondents reported this scheme operated until at least 1991. ${ }^{69}$ In 1989 the cooperative was active in protesting the loss of the Colville Post Office and sought to have the decision overturned. ${ }^{70}$ In the same year it argued with the Department of Lands and Survey over a new no-concessions policy preventing the store's mobile shop selling groceries in Farm Parks. ${ }^{71}$

The cooperative acted as an umbrella organisation for the Colville Action Group to administer funds for a community needs survey in 1986 (Scotts et al, 1987). It did the same thing in 1999 for Colville Social Services Cooperative until it could establish a Charitable Trust. $^{72}$ In 1996 the Colville School Board of Trustees (the Board) asked the cooperative to act as an umbrella organisation for grants for community buildings at the school. The Board described the cooperative as a "broad based community organisation". ${ }^{73}$ In 1987 the cooperative again acted as an umbrella group, this time for funding from the Community Organisation Grants Scheme (COGS) for a community

\footnotetext{
${ }^{69}$ Minute of AGM of CCS 21/10/1985. Ref: Youth Training Scheme.

70 Letter to Postmaster General from CCS 11/11/1986. Re: Closure of Colville Post Office: Letter from Office of the Postmaster General, to CCS 17/11/ 1986.

71 Report on meeting with Lands and Survey Department, Hamilton re No-Concession Policy, October 1986; Letter from Lands and Survey Department, Hamilton to CCS, 4/11/1986.

${ }^{72}$ Letter from M. Scotts and C. Tao to CCS, 4/11/1986: Minute of the AGM of Delphin Traders Ltd, 22/10/1986

${ }^{73}$ Letter from Colville School Board of Trustees to CCS 17/10/1996.
} 
crèche. ${ }^{74}$ This was the beginning of organised early childhood services in Colville. In 2002 the cooperative members donated their residual Sick Fund to the Colville Health Centre. ${ }^{75}$ The cooperative also supported the Colville Music Club, Colville Youth Club, the anti-mining campaign Coromandel Watchdog, school activities and provided the café venue for community fundraising dinners.

\subsection{TRANSITION PERIOD (1990-1999)}

\section{Membership}

The surviving Register's of Members for 1990 to 1999 show that there were almost a hundred members at the beginning of the Transition period (Table 6), evidence of widespread community support ${ }^{76}$. Based on 1991 and 1999 census data almost a third of all Colville residents were members. ${ }^{77}$

An apparent loss of 45 members between 1998 and 1999 was not explained. The pattern however is consistent with information provided by interview respondents who said many Foundation members withdrew around this time and new workers tended not to join the cooperative.

\begin{tabular}{|c|c|}
\hline Year & Number of members \\
\hline 1990 & 97 \\
\hline 1991 & $107(154)$ \\
\hline 1992 & 112 \\
\hline 1993 & 117 \\
\hline 1994 & 119 \\
\hline 1995 & 120 \\
\hline 1996 & 141 \\
\hline 1997 & 149 \\
\hline 1998 & $151(80)(65)$ \\
\hline 1999 & 106 \\
\hline
\end{tabular}

Table 6: Number of Members 1990-1999. Colville Cooperative Society

\footnotetext{
${ }^{74}$ COGS was a DIA fund to support community based essential social services. A larger organisation could administer grant the funds on behalf of a small informal community group.

75 Letter from A. Smith to CCS, 19 Oct 2001 responding to discussion at AGM on wind up of Cooperative Sick Fund. Letter from Dr McLeod, Coromandel Family Health Centre, 4/112002 suggesting Sick Fund goes toward Colville Health Centre.

${ }^{76}$ More than one Register was found for 1991 and 1998.

771991 and 1999 New Zealand Census of Population and Dwellings. Usually Resident population. Remainder Coromandel Census Area Unit.
} 
In 1996 the cooperative sought a legal opinion on the requirement that workers be members and was advised it could be in breach of Section 6 of the Employment Contracts Act (1991). Thereafter membership was voluntary. Membership began to decline soon after. ${ }^{78}$

Member rights changed. A 1991 change to the cooperative Rules prohibited the distribution of money or property to members on wind up of the Cooperative. All assets had to be distributed to like-minded organisation(s). ${ }^{79}$ The change was consistent with information provided by interview respondents, and confirmed in the cooperative Aims and Objectives, that the enterprise was to benefit the community as a whole, rather than individual members.

\section{Organisational Structure}

In 1996 there was misunderstanding amongst cooperative members about collective decision-making processes and roles. Members were unclear about the differences between the role of workers, coordinators and the committee. The committee described four functional decision-making forums to the 1996 AGM. These were staff meetings, meetings of coordinators, the committee and the $\mathrm{AGM}^{80}{ }^{80}$ During 1997 and 1998 the cooperative explored folding the company into the Industrial and Provident Society. This was to remove member confusion about the relationship between the two legal entities, reduce compliance costs and increase efficiency. Despite difficulties with the existing structure members chose to retain it. Unfortunately no records explain why members took that decision. ${ }^{81}$

In response to poor financial performance by the store, a further restructuring was undertaken in 1998. This reduced the number of jobs and hours individuals worked. The coordinator system was retained.

\footnotetext{
78 Letter from Purnell, Jenkinson and Roscoe, Barristers and Solicitors, to Secretary of CCS, September 1996.

${ }^{79}$ Minute of the 1991 AGM of CCS.

${ }^{80}$ Report of the Committee to the 1996 AGM of CCS.

81 Letter to Cooperative Members, "Legal Structure of Proposed Change". Notice of 1998 AGM of CCS August 1998.
} 


\section{Governance}

Problems with the governance arrangements arose in the mid-1990's. There was a lack of interest by members in serving on the committee, low attendance at AGM's and poor administration of the cooperative's regulatory obligations. Minutes of committee meetings and AGM's reveal concern about the business skills of committee members, and poor communication between stakeholders. Conflict amongst committee members began around this time, and persisted off and on for the next decade and a half.

This was consistent with reports from interview respondents that on average 12 members attended AGM's during the 1990's and only 30-40 members were active. In 1998 members expressed a lack of clarity about the respective roles of the cooperative and the store, and questioned the governance relationship between the two entities. ${ }^{82}$ Some expressed confusion about consensus decision-making and asked for an explanation; others disagreed with consensus as a decision-making method. ${ }^{83}$

\section{Contribution to Local Economy}

\section{Wages}

No wages data is extant for 1990-1994 or 1996. Based on Colville General Store and Colville Cooperative Society Annual Accounts from 1995, and 1997 to 1999 , just under half a million dollars $(\$ 463,772)$ was paid out in wages over these years. Were further data available and annual trends consistent, total wages paid out could be somewhere around a million dollars.

\begin{tabular}{|c|c|}
\hline Year & Wages Paid \\
\hline 1995 & 99,633 \\
\hline 1997 & 118,029 \\
\hline 1998 & 123,055 \\
\hline 1999 & 123,055 \\
\hline
\end{tabular}

Table 7: Wages Paid 1995- 2000. Colville General Store Ltd

\footnotetext{
${ }^{82}$ Minute of 2008 AGM of CCS.
} 


\section{Employment}

Drawing on data from interview respondents and governance documents the number of permanent part-time jobs during the Transition period was probably around 12. This continued into the first half of the Second Generation period.

\section{Financial Performance}

Annual accounts for only four years of the Transition decade were located (1995, 1997, 1998 and 1999). This made a comparison with other periods difficult. Some information relating to the missing years was drawn from interview respondents and governance records. Interview respondents described a change in the organisation as the highly skilled Foundation group withdrew and were replaced by people with weaker attachment to the cooperative and fewer business skills. Based on Colville General Store Annual Accounts for 1995,1997,1998 and 1999 the store made its first significant financial loss in this period when it lost just over \$20,000 in 1997. The cooperative however remained in a steady financial state and in 1995 gained Non Profit Body status under the income Tax Act (1994). However other problems were brewing.

The store posted its first major loss in $1997(-\$ 23,452)$, but made good profits the following two years. The pattern of year on year increased sales reversed between 1998- 2001 and fell by an average of $\$ 150,000$ per annum. Wages however continued to rise, thereby growing as a percentage of turnover. It was to be 2004 before annual sales exceeded those of the 1980's.

The financial viability of the café was problematic. In 1996 and despite its acknowledged social value, the committee recommended it close because of ongoing financial losses. ${ }^{84}$ In other parts of the business, major capital expenditure was required - to replace a walk in freezer in 1996, upgrade the café in 1997 to meet health regulations and urgent roof repairs, and again in

\footnotetext{
${ }^{84}$ Minutes of Committee meetings, 27/2/1996 and 26/3/2006.
} 
1997. In 1997 a theft of over $\$ 30,000$ was discovered ${ }^{85}$ Customer credit was a continuing issue and in 1997 the number of credit accounts was again reduced. Two stock takes a year were initiated. ${ }^{86}$ The cooperative took a $\$ 20,000$ bank loan in 1999 to keep the store afloat. ${ }^{87}$

\subsection{SECOND GENERATION PERIOD (2000-2010)}

\section{Membership}

Limited membership data was found for this time period. ${ }^{88}$ The secretary of the cooperative reported to the 2006 AGM that details of past members had been lost. ${ }^{89}$ In 2007, no new applications for membership were put forward for approval. ${ }^{90}$ This is consistent with reports by interview respondents that membership declined during this period. A further factor may have been a change in 2002 to an annual, rather than one-off, subscription fee. No subscription renewal notices for any year were found. Members were possibly not aware of the need to renew membership annually, and were removed from the Register of Members when they failed to do so.

For 2005, the only year in the 2000's for which there is a Register of Members, 244 members are recorded. This figure was most likely drawn from a list reconstructed after the member database was lost. The accuracy cannot be guaranteed. It seems unlikely membership increased by almost one hundred over a four-year period (2000-2004). Minutes from the 2009 AGM record member's unhappiness with maintenance of the cooperative's Register of Members, and doubts over its accuracy. ${ }^{91}$

\footnotetext{
${ }^{85}$ Committee Report to AGM, 1997.

${ }^{86}$ Minute of 1998 CCS AGM. Committee Report.

${ }^{87}$ BNZ Business and Farming Term Loan Agreement, 22/10/1999.

${ }^{88}$ Pers com Lora Mountjoy 22/8/2010.

${ }^{89}$ Report from Phoebe Look (Secretary) to the 2006 AGM of CCS, 18/11/2006.

${ }^{90}$ Minute of 2007 AGM of CCS 6/10/2007.

${ }^{91}$ Minute of 2009 AGM of CCS 16/10/2009.
} 


\section{Organisational Structure}

The organisation structure remained the same for the first part of the Second Generation period. Committee minutes confirmed the organisation had the same four decision-making forums as described to members in $1996 .^{92}$ The labour contract however was terminated in 2003.

A store manager was appointed in June 2004 and the coordinator roles disestablished. The manager reported to the committee. The role remained until 2007, but was disestablished because the structure had not worked well. ${ }^{93}$ The committee took on day-to-day management of the store and staff. In response to falling sales and financial losses there were further restructurings in 2006 and 2008 to reduce costs and gain efficiencies. The committee remained in a direct management role throughout. ${ }^{94}$

The organisation's structure was however an ongoing source of confusion for members. It led to a lack of transparency and accountability, and conflation of management and governance roles.

\section{Governance}

In the Second Generation governance was weak and conflicted. The committee was unable to deal with challenges caused by a declining population, changing community and competition from Big Box retailing ${ }^{95}$. Governance and management roles became conflated; to the extent they were indistinguishable. The documentary evidence was consistent with the perception of interview respondents that the cooperative did not have people with the skills to exercise good management or stewardship at this time. This

\footnotetext{
${ }^{92}$ This differs from and was lower than the limit decided in 1998.

${ }^{93}$ Colville Store Consumer Survey July 2005; Minute of Committee Meeting 24/5/2004; Office Administrators Report to AGM, 22/10/2008; Directors report to AGM, 2/10/2005:

${ }^{94}$ Minute of 2009 AGM of CCS 16/10/2009

${ }^{95}$ Big Box Retailing (BBR) are large national or international retail chains such as Pak N Save, Warehouse or Bunning's who operate out of warehouse style outlets. BBRs pull retail purchasing power from small towns to centres with these outlets. Small businesses can't compete on price with the superior purchasing power of a large chain. Smaller rural businesses were negatively affected by BBR in NZ and other jurisdictions (Stockwell, 2009).
} 
took the organisation to the brink of financial collapse and reduced its ability to function as a business and as a cooperative.

Members were unsure if the organisation was a business or a cooperative and where responsibility for management of the employees lay. ${ }^{96}$ From 2000 to 2004 the committee attempted to fill the management void left by the demise of the worker cooperative, store coordinator and manager roles. The employment of a manager was designed to solve this problem, but instead had alienated workers and customers even more. Business problems escalated. The expertise of committee members was questioned in a wide range of documents from this period. ${ }^{97}$

Over this period the committee also assumed greater powers than some members saw as acceptable. The 2005 AGM directed the committee reinstate the required 50:50 worker/consumer committee balance. The secretary raised concern about the committee's role in day-to-day store business decisions ${ }^{98}$. Minutes of meetings 2000 - 2004 show the committee was more heavily involved in day-to-day store decisions than it was in the governance of the cooperative. ${ }^{99}$ This was consistent with information provided by interview respondents who served on the committee. They reported spending time dealing with employee employment, training and communication issues, and struggling with an "out-of-date" organisational structure. ${ }^{100}$

Meetings with the company accountant in mid 2005 reveal the committee was in a direct management role, but struggling to understand the store's poor financial performance. ${ }^{101}$ Concern about the committee's business skills was consistent with interview respondents, who reported the committee response to problems didn't seem to work. Documents revealed a committee with

\footnotetext{
${ }^{96}$ Minute of AGM of the CCS 27/4/2001.

97 Minute of committee meeting 15/2/2000. Need for business skills training for committee members noted and again in 5/7/2001. Committee minutes, 11/10/2004 report summer 2003/2004 period was "chaotic".

${ }^{98}$ Minute of committee meeting 20/5/2005.

${ }^{99}$ Minute of committee meeting, u/d. Report from Fred Look: 'Management Structure of the Colville Store'.

${ }_{100}$ Minute of committee meeting, 22/6/2005

101 Minute of Committee meeting, 22/6/2005: Minute of meeting with P. Anderson, company accountant $12 / 07 / 2005$.
} 
limited business skills, knowledge of employment law or people management skills. The cooperative also failed to file annual returns to the Registrar of Industrial and Provident Societies for 2003 - 2006, and 2007 - 2010.

In 2006 there was deep concern amongst members about the state of the cooperative. The skills of committee members were called into question and a subcommittee set up to deal with a growing number of employment grievances. ${ }^{102}$ The new committee did not function well either and a Special General Meeting was held to replace two members who resigned shortly after their election. New committee members struggled to understand their role and responsibilities. ${ }^{103}$

The 2009 AGM aired issues of human resources and communication described as "in breakdown". A new committee was elected but a governance training workshop was poorly attended. Despite this, a small but critical mass of members reasserted member democracy and committed to rebuilding a viable business based on the cooperative's aims and objectives.

\section{Contribution to Local Economy}

\section{Wages}

Based on Colville General Store Ltd and Colville Cooperative Society Annual Accounts and a Wages Summary for 2004-2006, just over $\$ 1.5 \mathrm{~m}$ in wages was paid out between 2000 and $2010(\$ 1,550,796)$ (Table 8).

A drop in wages paid between 2006 and 2008 reflected a reduction in the number of jobs to control costs and bring wage costs in line with reduced sales. Reducing the wage costs helped slow the store's financial losses.

\footnotetext{
102 Minute of AGM of CCS 22/11/2006.

${ }^{103}$ Special General Meeting of CCS 9/3/2005.
} 


\begin{tabular}{|l|l|l|l|}
\hline Year & $\begin{array}{l}\text { Wages } \\
\text { Paid }\end{array}$ & Year & Wages Paid \\
\hline 2000 & 130,937 & 2006 & 155,251 \\
\hline 2001 & 120,363 & 2007 & 155,251 \\
\hline 2002 & 122,744 & 2008 & 160,800 \\
\hline 2003 & 131,274 & 2009 & 150,688 \\
\hline 2004 & 139,274 & 2010 & 130,584 \\
\hline 2005 & 153,603 & & \\
\hline
\end{tabular}

Table 8: Wages Paid 2000- 2010. Colville General Store Ltd

\section{Employment}

By the end of the Second Generation period job numbers had settled at around 75 per cent of the previous Transition decade, and 40 per cent of the early and particularly buoyant Foundation period.

\section{Financial Performance}

In 2001 the store made a second large loss $(-\$ 38,858)$. Lack of data made it difficult to identify why these losses occurred. A comparison between sales and stock values in 1987 and 1997 suggest a potential problem. Over that ten year period the stock value increased by over 340 per cent, while the value of sales increased by only 5 per cent. The store had more funds tied up in stock but lacked matching sales. Year on year sales were also falling.

These financial challenges overwhelmed the cooperative in the Second Generation period. The store posted a series of financial losses and the cooperative's own financial reserve depleted as it sought to mitigate the impact of accumulating losses on jobs, cash flow, stock and debt repayment. Customer satisfaction fell, the number of customers declined, and stock level and variety was reduced. Wages and management costs rose and profitability on turnover declined markedly. ${ }^{104}$ The cooperative was unable to sustain the number of jobs it previously had.

\footnotetext{
${ }^{104} 2000$ and 20005 losses were each in excess of $\$ 30,000.2007$ and 2008 losses were between $\$ 17$ 18,500. The cooperative made loans to the store in $2000(\$ 14,000)$ and $2003(\$ 30,000)$. The latter was a bank loan to the cooperative, which was on-lent to the store.
} 
The store struggled with competition on basic grocery items from supermarkets and chain stores in larger centres. Basic supplies like bread and milk were important because they brought customers into the store. ${ }^{105}$ The impact of new supermarkets and retailers in larger centres within driving distance of Colville was significant. Interview respondents confirmed travel out of the area was more common. The roads were better and people bought groceries on these trips. Stockwell (2009) found Big Box Retailers (BBR's) and chain supermarkets had a long-term negative impact on rural retail businesses in Taranaki. This was also the case in Colville. BBR's pulled the purchasing power from Colville and Coromandel, to Thames, Whitianga and Hamilton.

On top of increased competition there was a major loss of population. In 2001 there were 621 residents in Colville; in 2006 there were only $306^{106}$. Interview respondents and census data profile an older, sicker population. This left a smaller pool of people from which the cooperative could draw for workers and governance, and a smaller customer base. This presented challenges the cooperative was poorly equipped to deal with at the time. The impact of increased competition from larger centres, population loss and poor management was confirmed in company director reports, governance records and by interview respondents. ${ }^{107}$

Based on Colville General Store Annual Accounts (2000-2010), the store made losses in 2000, 2005, 2006, 2007 and 2008 (Figure 8). It was unable to repay loans totalling $\$ 44,000$ from the cooperative in 2000 and 2003 . Rural delivery grocery orders fell and the store withdrew this service in 2000. Shoplifting increased. ${ }^{108}$ The skill levels of workers were a problem. Free training courses were offered in 2001, but no workers took up the offer. ${ }^{109}$ The store customer base fell by 19.5 per cent between June 2003 and June

\footnotetext{
${ }^{105}$ Committee Report. June Activity Summary, 22/7/2004

${ }^{106} 2001$ and 2006 New Zealand Census data provided by TCDC. The Council has population data of varying levels of detail for 1991-2006.

${ }^{107}$ Report to 2005 AGM from Tony Wasley. Director, CGS, 2/10/2005.

${ }^{108}$ Committee minutes, 29/5/2000

${ }^{109}$ Committee minutes, 5/7/2001
} 
2004. The store responded by discounting milk, bread, alcohol and meat to encourage customers back. ${ }^{110}$ However this strategy did not work very well.

\section{Colville General Store Profit/Loss 2000-09}

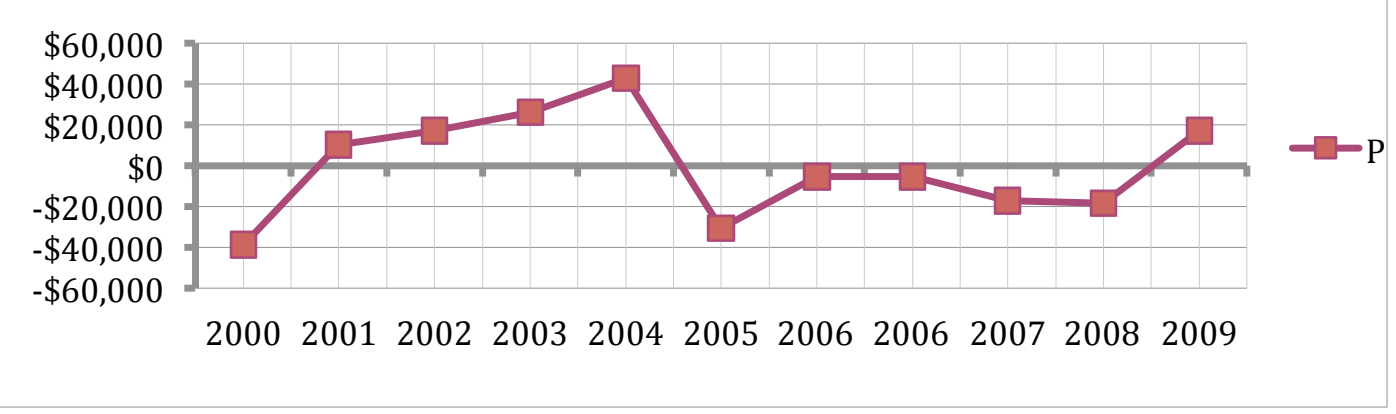

Figure 8. Annual Profit and Loss 2000-2010 .Colville General Store Ltd

Sales and customer satisfaction continued to fall and costs to rise. A computerised point of sales system was installed. In 2005 the store posted its biggest loss since 1997 with a total movement of over $\$ 70,000 .{ }^{111}$ A stock deficit anomaly of $\$ 30,000$ - 50,000 was also identified in 2005. The committee and accountant believed theft and poor stock management was largely responsible. Fewer customers and competition from supermarkets exacerbated the other problems. ${ }^{112}$

In response to these results the accountant suggested business training for committee members, and folding the store into the cooperative legal structure, observing "this shop is not just a business, it is a community asset and needs to reflect that". ${ }^{113}$ A second accountant noted "slippage in cash taking's not banked" and "goods taken without being paid for", as factors in the loss, along with increased wages without increased sales, incorrect pricing, fewer customers and a poor summer season. ${ }^{114}$

\footnotetext{
${ }^{110}$ Committee minutes 22/7/2004. June Activity Summary Report

111 Committee minute's 24/5/2004 noting difficulties between manager and staff; Letter from P Anderson and Associates to CGS: Financial Data Year Ended 31 March 2005. 29/9/2005

${ }^{112}$ Committee minutes, July 2005; Letter from P Barker, Accountant to CGS, 8/9/2005

${ }^{113}$ Letter from P Anderson and Associates to CGS: Financial Data Year Ended 31 March 2005. 29/9/2005

${ }^{114}$ Letter from P Barker, Chartered Accountant to CGS. 8/9/2005
} 
Management reverted to a newly elected committee in 2006. Financial results improved a little in that losses were smaller. ${ }^{115}$ In 2007 the store had trouble paying its monthly invoices. Further losses were made in 2006, 2007 and $2008 .^{116}$ In 2008 a further restructuring was undertaken and the number of jobs again reduced. Despite a busy summer season the store was close to insolvency a few months later. Turnover had dropped further, gross profit margins had deteriorated to less than one per cent, and wages were 13.5 per cent of turnover. Company equity had deteriorated, but some cash reserves remained. ${ }^{117}$ Further restructuring to reduce costs was undertaken.

These measures had an effect and from 2008 the business processes improved. The store was no longer reliant on overdraft to pay its normal bills and wage costs were under control. There was more efficient stock management and changes to the petrol payment schedule helped manage cash flow better. Customer interest increased, more local crafts were stocked, staff training was undertaken and the bulk food room was restored. In 2009, the last year for which there was available data, the store posted a profit after five straight years of losses.

The café was a problem. It was leased out in 2000 but the leaseholder left just before the summer season. ${ }^{118}$ The café made losses in 2002 and 2004 under cooperative management, and was again up for lease in 2004. At the 2005 AGM the café was described as "dysfunctional". In 2007 there was unpaid rent. The café made a further loss in 2008 and was up for lease, and in 2010.

\section{Sustaining the Environment and Promoting Community}

There was evidence both the environment worker role and the stocking of organic, healthy and bulk foods in the store was under pressure from mid

\footnotetext{
${ }^{115}$ Minute of the CCS AGM 28/11/2006.

${ }^{116}$ Minute of committee meeting, 7/11/2007

117 Office Administrator Report to AGM of CCS 22/10/2008; Letter from P. Barker, Accountant to CGS, 29/7/2008

${ }^{118}$ Minute of Committee meeting, 23/11/2000
} 
$2004^{119}$. Interview respondents reported a lack of healthy, bulk and organic products in the store. The environment worker role was disestablished soon after. The environment worker also audited the cooperative's own practices for environmental impact. With the demise of the role that oversight lessened. ${ }^{120}$ The store had struggled for many years to deal with the volume of summer visitor rubbish dumped in its recycling bins. It petitioned the TCDC from 2002 to 2006 for public rubbish bins. ${ }^{121}$ Records reveal the cooperative was active around supplier use of non-biodegradable packaging, genetic engineering and government requirements for heat treatment of imported pulses and grains.

\subsection{CONCLUSIONS}

From the middle of its second decade the cooperative struggled to find the right people for its governance committee. This became more difficult as the community became smaller. The organisation's structure was not always clear to members, and there was conflation of management and governance. This created less transparency in decision-making and compromised the 'one step removed' distance required for the committee to exercise independent oversight of the store. For much of its history however, the store had been well managed and profitable. Over the last decade it had been less well managed, and less profitable. It reached a very low point in the late 2000's. The individuals who brought the store back from the brink of insolvency then did a good job in turning the financial results around. Relationships within the cooperative, and between the cooperative and the community, however were at a low point.

The cooperative had demonstrated support for many community and environmental initiatives, and provided employment and a community meeting place. In this respect it had met and continued to meet its aims and objectives, albeit not consistently.

\footnotetext{
${ }^{119}$ Discussion Document: Working Cash Flow and stock levels, A. Curran, 8/6/2004

${ }^{120}$ Memo to Manager of CGS and CCS Committee from Environment Worker 21/11/2005.

${ }^{121}$ Letter to TCDC from CGS Environment Worker, 25/5/2004. Notes removal of Colville waste transfer station and reports ongoing problems with tourists dumping domestic rubbish outside store.
} 


\section{CHAPTER 6}

\section{“MY WAY OR NO WAY”. FINDINGS FROM THE INTERVIEWS}

\subsection{INTRODUCTION}

This chapter explores the perceptions of eleven people involved in the cooperative at different periods of its history. It reports their understanding of why a cooperative was established, how it operated and its impact on the individuals and community it services.

The chapter reports on their perception of the vision, leadership, decision making, performance and structure within the cooperative; the environmental initatives the organisation was involved in, and its major challenges, successes and failures. Respondents provided information about employment and household income derived from the cooperative.

The chapter provides a commentary to the document review reported on in Chapter 5. It reveals the 'lived reality' in an organisation and community the respondent's deeply identify with. Many female respondents consider their involvement in the cooperative was life changing and life enhancing.

Respondent data also provides commentary on the demographic and social history data presented in Chapter 4. This section of the chapter explores respondent perception of the major social and economic changes in Colville, with a focus on community attitudes and levels of cohesion, from the early 1970's up to 2010. The external and internal changes demanded the cooperative adapt to new circumstances. The respondent evidence is that the cooperative failed to adapt.

\section{Organisation of the Data}

The first section of this chapter presents respondent demographic data: age, gender, and education data, the roles they undertake in the cooperative and the cohort periods they report on. 
The balance of the chapter is presented in two different ways; as a general overview or summary of key features of a subject area (Section 2) and, under the four cohort periods adopted for this study (Section 3). This organisation was chosen because either the amount of data in each subject area varies considerably, or the interview questions were designed to elicit summative data, for example respondent views of the cooperative's major challenges and successes.

Section 2 presents the key features of the following subjects:

- Vision and Purpose of the cooperative.

- Employment and Household Income: relationship between the cooperative's activities, local employment and household incomes,

- Community Support and Environmental Stewardship: support for community services and facilities, and environmental initiatives;

- Challenges and Successes: major challenges and successes, and critical factors.

Section 3 presents data in the four time periods (cohorts). Pre Cooperative (pre September 1978); Foundation (1979-1989); Transition (1990-1999) and Second Generation (2000- 2010). The subjects presented by cohort are

- Community Attitudes and Levels of Integration, which reports on community social and economic changes over the last forty years, and

- Leadership and Governance, which reports on the vision and purpose of the cooperative, its leadership, decision-making processes and governance.

The cohort framework loosely corresponded to the main stages of the Cooperative Degeneration theory reported on in Chapter 2. The cohort framework was conceived however primarily an organising tool, rather than a map of the collective life of the organisation. 


\section{Respondent Relationship to the Cooperative}

Most respondents used the terms "coop" and "store", and did so interchangeably. Few respondents perceived any difference between the Colville Cooperative Society and Colville General Store Ltd. In respondent's minds the store was the cooperative, and vice versa. This representation reflects a key finding from the document review that governance and management functions of the two entities were almost completely conflated. Respondents reflected on the difficulty that caused.

Respondents expressed a close, almost fond relationship with the cooperative and store. Also anger and frustration, but never disinterest. A strong sense of ownership and concern about the well being of the cooperative and store was conveyed to the researcher.

The exact years in which respondents were involved in the cooperative were difficult for some to recall. For most the cooperative and store had been an integral part of their lives and when specific events happened was blurred. Significant events were recalled more easily. This chapter captures the ebbs and flows of change, influenced invariably by the benefit of hindsight and vagaries of human memory.

The voices reported here represent a unique social history within the New Zealand social development landscape. Other cooperatives with similar radical social change and development aims as the Colville example emerged in New Zealand's last wave of cooperatives in the 1970's and 1980's. That movement subsequently collapsed completely and very few of those cooperatives are extant in New Zealand today (Balmore \& Patmore, 2009) ${ }^{122}$. A similar collapse occurred in Australia and United Kingdom. However, it is these very principles that the UN and other development institutions now call

\footnotetext{
${ }^{122}$ The Colville Cooperative is similar to Balnave \& Patmore's (2008) description of Rochdale Consumer cooperatives. These cooperatives adhere to the original labour emancipation principles of the Rochdale Pioneers (1844), described in Chapter Two.
} 
on cooperatives to adopt as the foundation for effective, sustainable, self-help enterprise for poverty reduction and community controlled development.

\subsection{RESPONDENT DEMOGRAPHIC DATA}

All eleven respondents are part of two or more cohorts (Chapter 3, table 3 ). This reflects the relatively long time many had been in the cooperative.

Five respondents were living in Colville prior to 1978. They are the PreCooperative Cohort. Six respondents were part of the pioneer group who started the cooperative and ran the store as a worker cooperative for the first decade. They are the Foundation Cohort, from late 1978 through to 1989. Four respondents were part of the group who took over running the cooperative as foundation members withdrew. They are the Transition Cohort, from 1990 to 1999. Six respondents are part of the group who governed the cooperative and worked in the store over the past decade. They are the Second Generation Cohort, from 2000 to 2010. At September 2010 three of the six Second Generation respondents were still actively engaged in governance or worker roles.

Two respondents were long-term Colville residents and customers of the store. Neither had worked in the store or been members of the cooperative or alternative lifestyle community. They represented a small Community Cohort. Both respondents (one male, one female) have lived in Colville since the early days of the cooperative's existence (since 1978 and 1979 respectively) and provided a contemporaneous, albeit not representative, external perspective on the cooperative and local community.

\section{Respondent Gender}

The respondents included women and men resident in Colville, Coromandel, and Whitianga. Eight women and three men were interviewed. The gender balance reflected the high percentage of women who had worked in the cooperative over the years. 


\section{Respondent Ages}

The respondents varied in age from 35 years to 81 years. The female respondents ranged in age from 39 to 68 years. The male respondents ranged in age from 58 to 81 years of age.

\section{Respondent Education Levels}

Educational attainement varied from one year of high school education through to post-graduate degree, although the majority of respondents did not have a university level education. Two of the 11 respondents had completed a university degree.

Female respoondent educational attainments ranged from no tertiary qualifications, through to a Masters level degree. The highest qualification held by five of the eight women was a high school qualification (School Certificate). Two women had completed undergraduate university degrees; one held a masters degree. Another female respondent had completed papers toward an undergraduate degree. One had three years high school education and held an entry level trade certificate.

Two male respondents provided information about their education qualifications: one completed high school and left without qualifications; the other completed one term of high school. Overall, the level of education qualifications of the respondents was consistent with national figures for comparable age groups ${ }^{123}$. The educational attainment of rural and urban New Zealander's does not vary a great deal. Seven of the ten respondents (70 percent) who provided information said their highest qualification is a high school qualification. Three ( 30 percent) had tertiary qualifications.

\footnotetext{
${ }^{123}$ National average for secondary qualifications is between 65.6 percent and 78.5 pecent of the population, over three age ranges from 35 years to 65 years. Tertiary qualifications are held by between 14.9 and 24.2 percent of the population, over the same age ranges. Social Report, 2010. Ministry of Social Development. The ranges include eight respondents; two are several years outside it, and at 81 years one respondent is a lot older.
} 


\section{Time Involved in the Cooperative}

The length of time respondents had been involved in the cooperative and store varied a good deal. Most had been members for a long time.

Some respondents were paid workers for relatively short periods but served in governance or other voluntary roles for quite long periods of time. Other long time members or paid workers had never served in governance roles.

The length of time respondents were involved in governance roles varied from never (two people), through to 14 years. Four respondents were involved in governance roles for five or more years. The length of time the nine respondents who had been employees worked in the store varied from not at all, up to 18 years $^{124}$. The longest serving employee was also the youngest respondent. Five respondents worked in the store for five or more years. The majority were employed for between four and eight years, although not necessarily all year round during that time. Some held summer jobs over a number of years.

The average number of years respondents were involved in either paid or voluntary roles is quite long at almost 12 years, the range being from two years to 17 years. Just under half (five) had been involved for ten years or more. Eight respondents were active in the cooperative at two or more different periods of time, sometimes with relatively long periods between these. $^{125}$

\section{Respondent Roles in the Cooperative}

The nine respondents who had been members or paid workers had between them undertaken most of the roles in the cooperative and store, the two exceptions being accountant and manager. Between them they had

\footnotetext{
${ }^{124}$ This includes two years as a Youth Trainee. This scheme existed from the first half of the 1980 's, through to at least 1990.

125 "Active involvement" refers to engagement beyond simple membership, for example serving in a governance role, as a volunteer or as a paid worker.
} 
undertaken store counter work, chef, cafe waiter, stock buyer, youth trainee, mobile store, office administration, audit, bread room (rural delivery groceries), bulk store, store coordinator, cooperative committee of management, company director, environment worker, training and building and property maintenance roles.

Many respondents had a long history with the cooperative and had undertaken a variety of roles, moving in and out of paid work or governance roles over extended periods of time. Others had continuous involvement for a number of years, and then withdrew completely. One respondent served in governance and other volunteer roles for 13 years. Several were involved in the first few years, withdrew, and later returned to active involvement after a break of 20 or more years. Two respondents had been members for a long time, but had never worked in the store.

\subsection{FINDINGS FROM THE INTERVIEWS}

\section{Vision and Purpose of the Cooperative}

The respondent understanding of the vision and purpose of the cooperative did not vary in relation to the time period they had been involved in the organisation. There was strong consensus across time and around three ideas. These were providing employment to enable people to stay in the area, securing food and other essential supplies, and supporting the local community in a variety of ways.

Seven respondents believed a primary purpose of the cooperative was to create local employment, either directly or indirectly, by providing a sales outlet for locally produced goods or by fostering employment opportunities. Three believed the idea was for available employment to be shared amongst as many people as possible. One respondent from the Pre Cooperative and Foundation cohorts thought a communitarian, socialistic driving force was behind the forming of the cooperative. The vision she recalled was for a whole village of cooperatives including a garage, mechanics shop, housing and 
other businesses. Another thought the cooperative's purpose was to seed other employment opportunities and do business in an ecologically sustainable way.

Eight respondents thought the purpose was to support and give back to the community in some way. This included reducing the need to travel outside the area, supporting the community to meet its own needs, acting as a community resource and supporting new community health and education projects, or whatever else the community needs. One respondent articulated a vision of the cooperative as an enterprise founded on a philosophy of equality and egalitarianism. People working in whatever way they could for the greater good of society.

Seven respondents believed that securing supply of essential goods for local consumers was a fundamental purpose. Six thought access to food, in particular affordable, healthy and vegetarian bulk foods, was the purpose. For one respondent the purpose of the cooperative was to keep petrol pumps in Colville.

\section{Employment and Household Income}

Seven respondents had worked in the store and provided information about the contribution that income made to their household income. All reported the income from the cooperative made an important contribution to household income. Three households lived entirely off store wages; for another the wages was the main source of household income. For two other households the wages were initially a supplementary source of income, but later became a larger percentage when the family circumstances changed. One respondent reported her wages were critical to the household income because the dole wasn't available in Colville.

Two respondents reported their store wages had made up $15-20$ per cent of household income year round. This had increased to 30 per cent in one 
household and to 60 per cent in another when other income sources disappeared.

A profit sharing contract, between the store and an alternative lifestyle community, to run a summer mobile shop employed ten people and enabled $\$ 25,000$ to be raised over a four year period. Although not attributed to individual households, the money raised paid off the community's land. The second hand clothes exchange run by the store made a big difference to one family being able to stay in Colville, along with the availability of bulk chook and goat food, which increased the family's semi-self sufficiency.

Two respondents found they no longer had to leave Colville to find work because this was now available at the store. Another had found it very difficult to earn a living in Colville prior to the cooperative. Local work took pressure off this household. One respondent had found it less expensive to live in the 1990's and store wages had been enough for her household to live on then. Increased living costs meant the wages were no longer sufficient to support her family and other income was needed.

\section{Support for Community Services}

Ten of the eleven respondents believed the store was a community service and asset. The store and café played a pivotal role as meeting places for the whole community, providing essential services such as food, petrol and employment.

The majority of respondents (seven) reported the cooperative played a role in the establishment of new community services and facilities. This had been achieved through sponsorship, or acting as an umbrella legal entity through which community grants could be administered. New initiatives, projects and facilities supported by the cooperative included the Colville Music Club; Colville Youth Club; anti-mining campaign Coromandel Watchdog; early childhood centre; sponsored school activities; and Friday night community fund raising meals in the café. 
The cooperative took an active role in helping to resolve community issues through facilitating community meetings, or by taking direct action to deal with individuals. Three respondents cited examples of the cooperative's alternative justice response to theft. The cooperative did not involve the police and accepted financial restitution from offenders.

Two respondents talked about a store youth trainee scheme in the 1980's that provided young people with supervised work experience. One respondent had secured permanent work in the store as a result of being a trainee. The youth scheme had operated until the early 1990's, after which demand for it had diminished as there were fewer teenagers in the community.

\section{Environmental Initiatives}

Opinions were mixed amongst the six respondents who provided information about the cooperative's environmental sustainability initiatives. Four respondents thought a good effort had been made and described a wide range of activities. Two respondents didn't think the cooperative could claim any environmental achievements.

The activities reported included employment of an environment worker to research and source healthy and environmentally safe products for the store; advertising environment issues and campaigns in the store; stocking organic products; banning the sale of chemical spray products; providing a depot for recycling of rubbish; installation of a transpiration field waste water system; building a flood bank behind the store property to protect the village from flood; providing information about issues of concern within the community such as the use of the agricultural chemical 245T; support for the anti-gold mining campaign Coromandel Watchdog; and dealing with rubbish generated by summer campers.

Two respondents felt the cooperative had no environmental achievements. Both were Transition and Second Generation respondents. One claimed no awareness of environmental initiatives, but then talked about the environment 
worker. The second respondent felt the cooperative couldn't claim any environmental achievements because plastic had been burned on the premises, rubbish not been adequately with, and the store itself created a lot of waste.

Others thought the environment worker role had been crucial in raising awareness within the community about the impact of commercial products on the environment and human health. Two respondents felt disestablishment of the role in the mid 2000's impacted very negatively on the relationship with the community. One respondent reported the cooperative had entered a stage when the source and safety of the products was no longer considered important. This had taken away the store's point of difference and failed to follow the cooperative's environmental objectives. Another respondent however didn't like the influence the environment worker had on what was sold, and was quite happy to see this role disappear.

The cooperative had been one respondent's introduction to organics and environmental issues. This respondent thought that although an anti-chemical sprays campaign was extreme it had been necessary to bring about change. Two respondents complained a ban on selling fly spray didn't work. It had driven campers to shop in Coromandel town instead. They felt the cooperative's policy had pushed beliefs on to locals who didn't share them.

Two respondents thought the cooperatives effort to recycle its own rubbish and that of summer campers was an achievement. However, environmental practices had changed over the years, with different groups of people running the store. Another respondent reported rubbish was poorly dealt with during the Second Generation period. Plastic was burned or put in the local rubbish dump, and other rubbish built up on the cooperative's property.

One respondent thought the environment role had been lost and ridiculed over the past ten years, however this attitude was starting to change. 


\section{Major successes}

Most respondents thought the community services provided by the cooperative were its major success. The longevity of the enterprise, and its role in fostering people's personal development, were important secondary successes.

Six respondents reported the services provided by the cooperative had been essential to the survival of the community. Employment, and selling goods local people needed, was attributed with giving people a way to stay in Colville. One respondent believed at least six families relied on store employment. Without it, those families would leave Colville. Three respondents thought that providing employment in a rural area where work was difficult to find was the major success. One thought the cooperative had met its objectives of providing employment and community services, even when it wasn't going very well.

Longevity was the cooperative's major success for other respondents. One thought that overall the cooperative had had very good management over the years. It had successfully managed a marginal rural business for more than thirty years. Another respondent thought the longevity was a testament to the people who started it and the ideals they had. Two others thought financial success had been the cooperative's major achievement. That had allowed the organisation to survive, own a freehold business and be financially viable.

Fostering personal development, training and personal support were the cooperative's major success for four respondents. This included helping people with personal survival, offering refuge to people needing support, and providing opportunities for personal development. One respondent saw the cooperative as a training ground for people who then went on to achieve other things.

Two respondents thought the greatest achievement was a cooperative structure and working environment. Survival as a cooperative and functional 
workplace where people were equal, self-responsible, and worked together was a major success. So was community ownership. These respondents thought all sections of the community had genuinely been able to be part of the cooperative. Another believed a recent improvement in the working environment was the major success.

Modern tills and a computerised point of sale system, new petrol tanks and supporting creativity were thought, by one respondent respectively, to be the major success of the cooperative.

\section{Major Challenges}

Respondents offered a range of external and internal challenges faced by the cooperative. Some thought competition from supermarkets, competitive pricing and customer service had been the major challenges. Others believed becoming disconnected from the original values and principles, and from the community it served, had been the cooperative's major challenge.

Two respondents thought the major problems were limited stock, high prices and poor customer service over the past decade. One had avoided the store since 2000 because of poor customer service. Two other respondents thought competition from supermarkets meant the store needed a point of difference to attract customers, but that had been run down and lost. These respondents thought the cooperative needs new enthusiasm to recreate the store.

Some respondents thought maintaining the cooperative vision, commitment and energy had been the major challenge. One respondent thought that after the communitarian-minded Foundation period workers left the cooperative lost the connection between its objectives and its practices. Another respondent was unsure if the cooperative now had a community able to sustain it. Two respondents thought the major challenges were acting cooperatively, and consensus decision-making. Internal politics, personalities and conflicting agenda's was the major challenge for one respondent. This respondent 
believed that every time the cooperative had been in strife it was because of difficulties between people.

Failing to learn from experience was the major problem for one respondent. Repeating business mistakes, resisting efficiencies and change, and a backwater mentality were not effective business strategies. A second respondent thought business continuity had been the major challenge. Ordinary people were running a million dollar business and responsibilities had not always been shared.

One respondent thought the major problem had been over-staffing of the store. Another believed environmental sustainability was the major challenge.

\section{Critical Success Factors}

The two most critical factors in the cooperative's success for the eight respondents who provided information concerned commitment: commitment to keeping the store going, and commitment to the vision and values of the cooperative. Community support was a third important factor.

Four respondents articulated factors relating to a commitment to keep the business going, and need for a dedicated and skilled core group. One respondent thought the capacity of successive core groups over the past ten years had been low. Over the past eighteen months however some older cooperative members had revitalised the core group. Strong management was a critical aspect of business continuity for one respondent. She thought good financial management of the cooperative and strong management of the store were the most critical factors. Another respondent highlighted the role of workers in keeping the business going.

Member and worker commitment to the values and vision of the cooperative was the critical success factor for three respondents. One former store worker described the vision as "the reason, the base and the root of what the cooperative was all about". 
These respondents believed that first and foremost people needed to be working to the values and mission of the organisation; everything else would follow from that fundamental commitment. One respondent described the values and objectives as the cooperative's point of difference.

Three respondents mentioned local good will and custom, and the necessity for the cooperative to take the community along with it. One believed that when the community is divided, so too is support for the cooperative and the store.

\subsection{INTERVIEW FINDINGS BY COHORT}

\subsubsection{PRE COOPERATIVE PERIOD (1970-1978)}

\section{Community Attributes $1970-1978$}

Respondents described Colville at the start of the 1970's as a small and remote farming community. Poor roads and limited transport, lack of amenities, a limited number of telephones and a run-down general store had made life hard for residents.

The population started to grow dramatically from the mid 1970's when settlement of the alternative lifestyle communities began. This created a strained relationship between traditional farmers and the settlers. There was a clear division between the two communities, and prejudice shown on both sides.

Three respondents described the Colville General Store prior to 1987. It was difficult to buy good food. The store was run-down and the shelves were half empty. It was more like a dairy and on one occasion the only "decent thing" to eat was a packet of dates.

Three respondents recalled a food cooperative operating in the 1970's, before the cooperative was set up. Although no respondent could recall exactly when 
the food cooperative started, the best guess was 1975 in Colville and perhaps a year or two earlier in Coromandel town. The respondents recalled coordinating bulk food orders and packing and distributing goods from community halls in Coromandel and Colville. Three respondents believed this food cooperative had been the forerunner of the Colville Cooperative Society.

One respondent described the philosophy of people in the alternative lifestyle community. They had believed that pulses, beans, soymilk and vegetarian food were better than more traditional foods such as meat. This created a need for staples such as oil, brown rice, beans, oats, lentils, pasta, flour and sugar, for which the existing store didn't cater. That unmet demand opened the way for a food cooperative to operate, and eventually the cooperative store to be established.

\section{Cooperative Leadership and Decision Making}

One respondent said there had been an environment of idealism, communitarianism and experimentation in the alternative lifestyle community. A small group of people had met and conceived of a community-owned store in Colville. Two respondents recalled a small group of people with political or faith-based communitarian ideals had initiated a process to make this a reality. The group had met sometime prior to 1978, most probably in 1975 or 1976, through mutual connections with Karuna Falls community and the Values Party ${ }^{126}$. The group had included people with small business skills and access to financial assets. They had formed a trust to buy the Colville General Store, which had been on the market in late 1978. Two respondents described the Mapua Trust ${ }^{127}$ and Colville food cooperative as forerunners of the Colville Cooperative Society.

\footnotetext{
${ }^{126}$ The Values Party was established in 1972 and contested the 1972, 75 and 78 general elections. The party espoused an egalitarian, ecologically sustainable society; respect for nature; zero growth economy; anti-nuclear power and armaments; alcohol, drug and abortion law reform. It merged with the Green Party in 1990.

${ }^{127}$ The Mapua Trust was an agreement between three people. No Trust Deed is extant.
} 


\subsubsection{FOUNDATION PERIOD (1978 - 1989)}

\section{Community Attributes}

The seven respondents who provided information described the setting up of new community services and facilities to meet the demands of the growing population. There had been new opportunities for women. There were strong divisions between the traditional farming and alternative life style communities. The store had provided a focus for the community and was an important meeting place. It had provided a way for people to earn money, buy the goods they needed and so stay in Colville.

One respondent reported problems with parents bringing unsupervised children and teenagers into Colville village on Friday nights. While parents socialised at the restaurant, groups of children had regularly taken over the main street and table tennis club in the Colville Hall. Things had been broken, rubbish was left around, and teenagers on the beach had thrown bottles around the beach.

Two respondents said opportunities for women had been changing with the rise of feminism. The cooperative had given women with young children the opportunity to work, earn money and be involved in decisions. This had spawned the need for early childhood care. The cooperative had given women a new lease on life, utilised their existing skills and developed new business skills. Women had loved working in the cooperative. However not everyone embraced those changes - two other respondents reported a general reaction against feminism in the alternative lifestyle community.

The cooperative acted as an umbrella group in 1987 for funding from the Community Organisation Grants Scheme (COGS) ${ }^{128}$. The funding was to set

\footnotetext{
${ }^{128}$ COGS supports community based essential social services and is administered by the Department of Internal Affairs. COGS accept 'umbrella' organisations to which it pays a grant intended for a community group that is not a legal entity. The umbrella organisation must be a legal entity and administers the funds on behalf of the smaller community group.
} 
up a community crèche and had been the beginning of organised early childhood services in Colville.

Five respondents reported strong divisions between the alternative lifestyle community and farming community in the 1980's. One summarised it as a 'them and us' attitude. With a few exceptions, the farming community had not really patronised the store or cafe.

There had been a wide range of reactions from the farming community to the store being in the ownership of an alternative lifestyle dominated cooperative. Some in the farming community had been more able to accept the new settlers than others. The farming community as a whole had been a bit unnerved by the cooperative. Some farmers had been sufficiently affronted as to never visit the store. One community respondent reported some farmers had thought all alternative life style settlers were "wild pot-smoking nudists".

One male respondent described the cultural difference as amusing in hindsight. He described his shock on first seeing people sleeping communally and taking baths outside. He said "he just didn't know where to look". He had not agreed with the attitude the traditional farmers took to the new settlers, whom he had found to be mostly well educated, middle-class people.

\section{Leadership and Decision Making}

Four respondents identified two strong individuals as the leaders of the cooperative and store. The most significant had been a member of the Mapua Trust, a founding member of the cooperative, and the store accountant. The sustained vision of this leader as to how the cooperative and store could work had been particularly important. One respondent described a powerful visionary whom people recognised for his vision and business skills, and on which the cooperative depended. There was however strong group leadership in the cooperative at the same time as strong individual leadership. Five respondents identified this. 
Respondents reported the store and café operated as worker cooperatives in the Foundation period. There had been strong people with definite ideas about what to do and how to do it in the early days. People had taken a high level of responsibility, there had been regular staff meetings and everyone had had their say. A respondent who was a worker in the latter part of the Foundation period said coming into an organisation with group decisionmaking had been a completely new experience, and a big change from formal meetings. This respondent thought the group decision-making process had been mainly good but had been personal and destructive at times. Learning to make decisions and speak in meetings built her confidence.

Two respondents who had been company directors had seen it as a caretaker role and were happy to let the committee runs things. Only one respondent articulated a clear distinction between the governance role of the committee and the role of the worker cooperative running the store. The respondent identified the governance role as broader than the worker group, which effectively worked for the cooperative. The respondent said workers had contributed a portion of their salary to the cooperative as a donation. In turn these the funds had gone toward purchase of the store and the property.

\subsubsection{TRANSITION $(1990-1999)$}

\section{Community Attitudes and Levels of Integration}

Overall, respondents recalled fewer details of the Transition years than other periods of time. The seven respondents described the decade as the beginning of fundamental change in the cooperative and in Colville. There was an almost total withdrawal by foundation members from active involvement in the cooperative and store, and the community was also changing.

Two respondents said the population changed as parents started to leave Colville as their children reached high school age. The cooperative's Youth Trainee scheme was still going in 1990 but the number of young people 
wanting work experience had diminished, reflecting a smaller number of teenagers in the community.

The relationships between the farming community and alternative lifestyle community had however improved as work and personal relationships formed between individuals, and the new settlers were slowly accepted by farmers.

Foundation member withdrawal from the cooperative and permanent residence in Colville was experienced by those remaining as a 'mass exodus'. This had a negative impact on the management of the store with the loss of business skills from the community. Attitudes to the cooperative were changing. Many store workers had not wanted to join the cooperative and membership had fallen. Two respondents reported widespread minor theft and one large theft from the store. They felt this reflected a changing attitude in the community toward the store and amongst paid workers, with less loyalty and sense of ownership.

Store workers were increasingly drawn from the farming community and that brought a different set of values and experiences into a cooperative environment. One respondent felt the 1987 share market crash signalled a change in the population of Colville, and diminishing cooperative values within the community.

\section{Leadership and Decision Making}

One respondent reported cooperative membership had declined in the late 1990's and the AGM's were poorly attended. On average 12 people had attended AGM's and active membership was 30 - 40 members in total. This had led to a suggestion, sometime around 1997/1998, that inactive members be removed from the Members Register and their shares transferred to remaining members, thereby giving each active member more than one share. $^{129}$

${ }^{129}$ That proposal was not adopted by the cooperative. 
In the first half of the Transition period the business knowledge and skills of the last Foundation member still working in the store, and those of the acknowledged leader, was reported to be especially important. Another respondent reported the committee in the 1990's lacked business skills. This had led to effective loss of control of the store and cooperative, which became unaccountable to its members.

There was a move away from consensus decisions in the store. Five respondents raised this. Decisions had been made by longer serving workers, rather than workers as a group. Not all workers were members whereas previously they had been. One respondent believed much of the business knowledge and passion for the cooperative was lost between the Foundation and Transition groups. In the beginning everyone had had similar ideals and ideas, but as foundation members left and new people became involved not all the skills and knowledge had been passed on. Succession and training had been ad hoc.

Four respondents reported the jobs in the store changed. The roles were more discrete and bounded. Coordinators had been established to fill the leadership void left when the last member of the Foundation group withdrew in the mid 1990's. The coordinator role was based on a staircase system: when one coordinator was leaving a new one was trained up from amongst existing staff. Two respondents reported there had been fewer full staff meetings. The three coordinators met weekly and made business decisions, and had been paid a little more than other workers. One respondent strongly protested this change to the previous flat wage rate policy. Three other respondents said the coordinator system had worked well and had lasted from 1987 until 2004.

The new 1993 Companies Act had affected member's willingness to be directors of Colville General Store Ltd. Two respondents reported members had been worried about new director responsibilities. The new Occupational Health and Safety legislation, and Employment Contracts Act had created significant pressure on the committee and company directors. They had to 
identify risks and put systems in place to manage those, and develop written job descriptions and employment procedures. It had been a large amount of work to bring in structured employment contracts from the loose, flexible system that had previously operated. After this legislation came into force fewer workers had wanted to be cooperative members and membership had fallen.

\subsubsection{SECOND GENERATION PERIOD (2000-2010)}

\section{Community Attributes}

All eight Second Generation respondents reported there had been significant changes in the community. There was a significant loss of population; a move away from communal activities in alternative lifestyle communities; increased population churn and transience; a growing proportion of dependent individuals and households; and greater strain on community services and facilities. Respondents also thought the relationship between traditional farmers and alternative lifestyle settlers had however changed for the better by this time.

There was a much smaller community with fewer permanent residents and more holiday houses in alternative lifestyle communities. The number of local customers at the store had dropped and there were far fewer rural delivery grocery orders. Two respondents reported alternative lifestyle communities moved away from communal meals. More people lived in nuclear families and did individual household shopping. This had reduced the need for bulk supplies. Fewer farms jobs were available and fewer farm workers to buy supplies at the store. The loss of population was attributed by respondents to fewer people living in alternative lifestyle communities, and to children leaving the area for tertiary education.

All eight respondents reported a change in attitude to the community. A more transient population lived in rented homes and were less loyal to the community. Fewer people overall, and a smaller number of community 
minded people, had an impact. This was evidenced by difficulty in finding volunteers for community services such as the cooperative's governance committee, the postal centre, youth club, health trust, and Rural Women's Association. Many young adults still came to Colville seeking an alternative lifestyle but found that community was no longer large enough to support them.

Six respondents thought there was a greater proportion of dependants in the community, either because they were young, aged or receiving a government benefit. The working population was thought to be relatively small. One respondent thought half of all the residents in the northern Coromandel were not in employment. Two respondents thought people were generally less selfsustaining than previously, and didn't need to work because they received a government benefit. Another said the unemployment benefit was more than store wages. A third described the community as poor, with low education achievement, with a number of young parents and second generation unemployed families.

Six respondents reported high levels of drug and alcohol dependence and many sickness beneficiaries. The new Health Trust and the Social Services Collective was set up to meet the increased health and support needs.

Four respondents reported fluctuating numbers of resident children had caused difficulties in keeping the school and pre-school facilities open. The school had held on to two classrooms, but previously there had been four. Pre-school numbers had been recently been higher whereas two years previously the numbers had been so low closure was threatened.

Three respondents thought there were fewer peak summer visitors, but more traffic on the roads. They thought changes to holiday patterns meant visitors had become more spread out over the whole year. The overall increase in traffic was attributed to cheaper, more roadworthy cars and better roads. This enabled local people to travel more frequently and commute to and from work and the store. Peak visitor data from the Thames Coromandel District Council 
contradicts this perception to some extent. Peak traffic for 2005/06 and 2007/08 was over a 12-day Christmas/New Year period, and there were raised visitor numbers from January - March (TCDC, 2008).

Three respondents reported relationships between traditional farmers and new settlers had improved as the result of intermarriage, children going to school together and more people from a farming backgrounds working at the store. The community was perceived as more integrated than previously.

The changes in the community noted by respondents are consistent with other evidence: a 2005 company director report blamed a drop of sales on the loss of families from Colville, competition from supermarkets in Coromandel and Thames, changes to consumer buying patterns and better roads enabling consumers to travel further afield more easily. ${ }^{130}$ Census data showed a large drop in the Usually Resident population between 2000 - 2006, from just over 621 people, down to 306 people $^{131}$. The comparative data needs to be treated with some caution. The census mesh block area boundaries changed between 2001 and 2006. Two mesh blocks covering small settlements were omitted from the 2006 resident population data provided by TCDC (representing an estimated 20-30 people). Regardless of the relatively small discrepancies, it is clear there was significant population loss.

\section{Leadership and Decision Making}

Four respondents thought the committee struggled over the Second Generation period. The committee seemed to lack business skills and had abandoned consensus decision-making. Power became concentrated in the hands of a few people. There was poor communication amongst committee members, and between the committee and store workers. Two respondents reported some consumer members thought the cooperative no longer worked the way it should. One felt quite strongly that the cooperative should be directly funding community facilities, as well as providing jobs.

\footnotetext{
${ }^{130}$ Director's Report to Colville General Store Annual General Meeting, 2/10/2005.

${ }^{131}$ TCDC, 2010. Census mesh block area boundary differ between 2006 and previous years.
} 
One respondent who served on Transition and Second Generation period committees reported the committee role in 2004 was very different from that of the 1990's. Formerly the committee had met 3 or 4 times a year and made big picture policy decisions. In 2004 it was running the store on a day-to-day basis. Store workers had no interest in the cooperative, and the store was no longer able to operate as a worker cooperative. Committee members had spent their time dealing with employment, communication and training issues, rather than addressing the strategic direction of the cooperative.

Two respondents, one male and one female, felt the male members had dominated the committee. The male respondent described the environment as "an ideological battle" and "macho gender politics". The female respondent reported female members felt bullied by male committee members. One respondent had tried but failed to get the committee to reinstate a worker cooperative and to develop management and strategic plans. This respondent felt the business was falling apart and the cooperative was not functional at this time. Another respondent described the committee as divided and deadlocked in the face of management and business difficulties in the mid 2000's. The cooperative leadership was seen as weak and management of the store divisive and incompetent.

The cooperative's response to the problems was reported as short-term and ineffective. The cooperative didn't have the necessary business skills, knowledge of employment law or people management skills, according to one respondent. Another thought store workers in the mid 2000's lacked skills and had low productivity. Staff turnover was high. Five respondents reported weak governance, poorly skilled workers and poor communication. This environment had led the committee to employ a store manager to improve the business systems.

Seven respondents reported this appointment failed to work as intended. The store and cooperative were in a worse financial state a year after the manager's appointment. One respondent felt this was largely the fault of the workers; other respondents felt the manager was to blame. Four respondents 
reported workers decision-making powers greatly diminished over this period of time.

Three respondents felt the cooperative's policy on worker representation on the committee was circumvented. Worker members had not advised of meetings, no votes were taken at meetings, and a selected few members later made the decisions privately. One respondent said that in 2006 the committee lacked life, business and human resource skills. There had been no transparent decision-making process and the manager effectively controlled the committee.

Three respondents said the 2006 AGM had been a particularly important meeting. There was huge concern amongst members about the financial state of the store and the direction of the cooperative. A number of long standing cooperative members attended the AGM, or provided proxy votes, to elect a new committee able to work together and deal with the business and governance problems. One respondent reported the new committee proved dysfunctional and some members had quickly resigned. The store manager had resigned shortly thereafter. The situation made the respondent wonder if there was still a role for the cooperative. It appeared to her there wasn't enough energy in the community to make it a functional entity.

The committee had directly managed the store and workers after the manager left. A restructure in 2008 reduced staff costs and increased worker productivity. The committee had reportedly done a good job of getting the store back on its feet, but it had been is a very tense and stressful time with poor communication between the committee and workers. Another respondent believed the restructure meant everyone had been able to help make the decisions about the future of the cooperative.

One respondent believed there was little loyalty to the cooperative and no sense of ownership or commitment to the store amongst workers at this time. Another felt workers did not acknowledge the benefits of working for the cooperative. A third thought that overall, workers had been happy with the 
changes. This view was contradicted by a worker respondent who said they had resented their increased responsibilities and workload.

Two respondents thought the store never recovered from this period because the committee lacked the skills to rebuild relationships and the business.

Four respondents believed the cooperative lost its way at this time in decision making, quality of relationships, customer service and community support. They reported a feeling in the community that the cooperative was no longer behaving cooperatively. Two respondents said the committee and shop was effectively been in the control of a couple of individuals. One respondent described the boundary between management and governance as completely eroded. Committee members reportedly had a 'siege mentality' and reacted negatively to questions from members. Another respondent observed that while cooperative members had the power to vote at AGM's and Special Meetings, the committee also had wide ranging powers to make major decisions without the approval of the membership as a whole.

Two respondents reported a recent sea change within the cooperative. The committee elected in 2009 had reinstated the expectation workers become cooperative members. A restructure, and rebuilding of governance and business roles and skills, was underway. Several longstanding members with business, cooperative and human resource skills returned to the cooperative in mentor and support roles. The role of company director was made an active role tasked financial overview of the store and cooperative. These respondents observed that although the committee was still micro-managing, the store had more skilled and settled workers, the cooperative feeling was returning and decision making was transparent and inclusive.

\subsection{CONCLUSIONS}

Overall the respondents provide a useful commentary to the document review. The interviews provided data that supports the key findings of the document review. What most touches or influences people naturally varies, 
hence differing emphasis. For example the vision and primary purpose of the cooperative as expressed by respondents is a bit different to the documents. Respondents emphasise employment and community support: the cooperative's aims and objectives emphasise environment and social change. For some people the petrol pumps or rubbish were most important. For others it was the quality of governance and leadership or the quality of the working environment.

In other cases, individuals simply held a convinced view of events that differed from the written record. For example, the attribution of stock losses in 2005 to data input errors, compared to the accountant's analysis of theft and poor stock management, exacerbated by rapid population loss.

The changing balance of power between worker and consumer members was evidenced in the interviews and in the document review. Respondents reported gradual changes in the type and quality of leadership and governance over the history of the cooperative. It began with strong worker influenced leadership and governance. The worker members had strong leaders and representation in decision-making processes. Over time workers influence had diminished and consumer members had exerted greater control. This trend continued until a very small group of consumer members eventually had total control. Most recently there has been a revival of democratic and group decision making, facilitated by the re-engagement and intervention of several former members with a positive profile in the community.

In most cases there is strong correlation between the recollections of the respondents and the data from the review of documents reported on in Chapter 5, and with the relevant historical social context data presented in Chapter 4. Areas where the cooperative document data set and respondent data set tend not to correlate are

- Recollected dates, and documented dates

- Pre cooperative, and early foundation period history 
- Actions and policies ascribed to the store which the documents reveal originate from the cooperative, and vice versa

- Environmental sustainability and stewardship

- Perceived purpose of the cooperative, and the documented purpose and aims

- Explanations for poor financial performance, especially financial losses associated with the employment of a manager, and with theft and poor staff skills.

Weaker triangulation in these areas is influenced by the relatively long passage of time since some events occurred - people simply forget things that happened $20-30$ years ago. The small size of the core group dealing with the business start-up issues, described in Chapter 5, influenced respondent knowledge of pre and early cooperative events. Conflation in the minds of many respondents of the cooperative and the store into a single monolithic entity, is most likely responsible for incorrect attribution of some events and processes. 


\section{CHAPTER 7}

\section{A MIXED REPORT CARD. ANALYSIS AND CONCLUSIONS}

\subsection{INTRODUCTION}

This chapter presents an analysis of the data and draws conclusions from the research. The chapter integrates key findings from the social context (Chapter 4), the document review (Chapter 5) and interviews (Chapter 6). It considers these with reference to the cooperatives and development literature (Chapter 2).

The research design and data collection methods generated data considered in respect to five time periods, and across key subject areas, based on the literature on lifecycles in cooperatives. This approach allowed a synthesis of influences on the viability and sustainability of the cooperative, and its pattern of development across time. Causative and contributing factors to that pattern and performance were evidenced. This approach built data with breadth and depth, and provided for triangulation of data.

The adoption of a cohort framework drove the organisation of data into this framework. This method proved to have utility in applying a lifecycle approach to the development of the cooperative, and demonstrated the importance of using the literature to form an initial conceptual framework. The approach allowed for adapting and reconceptualising of this framework throughout the research as new data emerged from the case investigated.

The lifecycle approach to cooperative development is applied to the data based on Batsone's (1983) three stage lifecycle of cooperative development, and Cook's (2005) five stage cooperation degeneration theory. The cohort time periods proved to be reasonable proxies for life cycle stages of the cooperative (Table 10). 
The development of the Colville Cooperative was found to have characteristics of a modified version of Batsone's three stage, and elements of the Cook's five stage, cooperative degeneration theory, but with important differences. Similarities and differences are discussed later in the chapter.

Good practice principles from the development literature on cooperatives are compared with findings from the study data. The cooperative's adherence to good practice was found to be variable. Periods of strong governance and business performance were more likely to correlate to periods of good practice. Periods of poor performance and crisis in the organisation were more likely to correlate to periods of poor practice and loss of cooperative principles.

The cooperative's life cycle stages were also considered in the context of external social and economic changes in the Colville community, and the evolution of wider social movements with which the cooperative was closely identified.

\subsection{ANALYSIS}

The findings reveal a long cycle of cooperative growth, followed by stasis and decline. Early growth spurred by inward migration and tourism were capitalised on by strong management and governance. Periods of decline caused by poor business management, loss of cooperative principles and population loss were exacerbated to crisis point by poor management and governance.

Within the store, the cycles of growth and decline were repeated several times over the 32 year span of this study. For the cooperative as a whole there is a single, longer cycle of degeneration evidenced by loss of democracy, increasing divergence of member interests, increased conflict, rising costs and the loss of member and community support. 
Major demographic changes in the Colville community demanded the cooperative be adaptable and speak to leadership and business skill capacity. The cooperative exercised greater adaptability in times of rapid growth than it did in times of contraction. Over time the cooperative responded increasingly slowly to its problems. Despite considerable evidence of the need for a different structure, it has adapted this very little in 32 years, suggesting an inherent conservatism in the organisation that works against sustainability. Slow reactions to emerging business problems limited the potential of the organisation.

There have been periods of very good financial management, and times of poor financial management born of a lack of business skills. Periods of good financial management built cooperative wealth and assets, and safe guarded jobs. Periods of poor financial management created financial crisis's that took increasingly longer periods to recover from, and reduced the employment and other benefits to the Colville community.

On the other hand the cooperative has proven to be resilient, consistent with Birchall \& Ketilson (2009) findings that cooperatives are a particularly resilient form of enterprise, able to withstand crisis and protect livelihoods in hard times.

\section{Contribution to Community Economic Development}

Despite periods of struggle and failure the cooperative has in large part met its employment and local economic development aims and objectives. The contribution to local economic development has to be considered in the context of ambitious social and economic development aims and objectives, the small size of the organisation and remote location and the wider pressures on small rural businesses. Financial performance is important, as the store was the primary mechanism through which the cooperative met its Aims and Objectives. The store generated community-owned assets, created a cooperative community, provided natural foods, marketed locally produced goods, protected the environment and provided jobs and community services. 
It is estimated that by 2009 the cooperative had paid $\$ 3.4-\$ 4$ million in wages to local residents. These made an important contribution to local household incomes. The cooperative generated and sustained local employment opportunities over a long period of time, and in an area with few employment opportunities.

The cooperative has built up community owned assets worth at least half a million dollars. Because the Colville General Store has not been valued since 1986, the cooperative's realisable assets are most likely considerably more than this.

The cooperative helped numerous families and individuals manage seasonal fluctuations in income and periods of unemployment through extending credit, very often to the detriment of safe guarding its own cash flow.

\section{Financial Performance}

The Foundation and Transition periods were financially successful, although not without challenges, in managing a fast growing business and maintaining it as the more experienced workers left. In the first decade, sizable loans were paid off and cash reserves and assets accumulated. The rate of growth slowed and remained stable until 1997. After 1997 the financial performance of the store declined. It posted its first financial loss in 1997. Further losses were made in 2000, 2005, 2006, 2007 and 2008. The financial reserves of the cooperative were tapped in order to keep the store solvent and were depleted through loans that could not be repaid. Local customers abandoned the store. Tighter management was instituted and costs reduced. In 2009 the store returned to profit after the five straight years of losses.

\section{Sustaining the Environment and Promoting Community}

From its beginning the organisation was embedded in and reflected the environmental values and social concerns of the community it served. Over 
time it lost this deep connection and a way of doing business that was both profitable and sustainable. ${ }^{132}$

Throughout much of its history the cooperative actively supported environmental initiatives and community projects. That support lessened to a marked degree in the Second Generation period. The store went from stocking a wide range of healthy and organic foods, alternative medicines and environmentally safe products in the1980's and 1990's, to largely abandoning concern about product safety and healthy food in the 2000's.

Community support for the organisation was strong during the 1980's and 1990's. This evaporated during the 2000's. By the end of that period the store had a negative reputation for service, product range and attitude to customers. The organisation was no longer seen by some members as functioning as a cooperative.

\subsection{THE COLVILLE COOPERATIVE LIFE CYCLE}

The Colville Cooperative has demonstrated the capacity to recover from cyclical financial and organisational crisis. There have been a series of smaller cycles of degeneration and renewal within a longer overall cycle of decline. When this study was carried out the cooperative was at the end of what Cook \& Burress (2009) defines as the fifth and last stage of degeneration - choice. The cooperative was facing decisions about its survival.

There was initially strong commonality between members but, with time and growth, differences emerged. Worker and consumer member interests became increasingly divergent, the balance of control was disputed, grievances arose and conflict escalated. Eventually the organisation reached a cross roads - inevitable dissolution through accumulating financial losses or a resurgence of the cooperative vision.

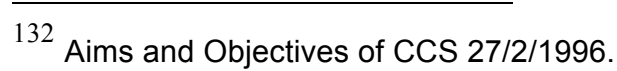


The case study cooperative expresses many characteristics of a modified Cooperative Degeneration theory, discussed in Chapter 2 (Batsone, 1983; Hind, 1999; Cook, 2005; Valentinov, 2007; Cook \& Buttress, 2009). When applied to the case study, cooperative degeneration theory was found to have validity, but with some important differences (Table 9). The degeneration theories focus on economic considerations throughout the life of a cooperative. The Colville Cooperative's motivations are primarily noneconomic and born of social and political dissonance. There are economic drivers, but they are balanced by the social drivers.

That balance was crucial. When the employment driver (worker interests) dominated, this was to the detriment of the organisation's financial performance and ability to provide other community benefits. When consumer interests (low cost goods and services) dominated, this was also to the detriment of the cooperative's financial performance and ability to provide other benefits to the community.

However, when the social and environmental drivers guided the cooperative, it did well. The balance provided what the members and the consumer community wanted. The worker cooperative was a crucial element in expressing the values, philosophy, aims and objectives of the cooperative. It was also the business powerhouse of the cooperative. The democratic space of cooperative power relations alluded to by Len et al. (2004) created an "emancipated social space" in which joint entrepreneurship and learning flourished (Len, et al: 2004: 4). When the worker cooperative broke down, the cooperative went into a pattern of long-term decline. 
Table 9: Life Cycle Phases for Case Study by Cooperative Degeneration Model (after Cook \& Burress, 2009)

\begin{tabular}{|c|c|c|c|}
\hline Life Cycle Stage & Key Features & Years & Colville Cooperative \\
\hline $\begin{array}{l}\text { 1.Economic } \\
\text { Justification }\end{array}$ & $\begin{array}{l}\text { Cooperatives arise from market failure. Collective } \\
\text { action to improve socio- economic situation. Form } \\
\text { around common geographic locales, grievances or } \\
\text { visions, and amongst relatively homogeneous } \\
\text { groups of people. Strong sense of member } \\
\text { ownership, control and commitment. }\end{array}$ & $\begin{array}{l}1970-1980 \\
\text { (pre- } \\
\text { cooperative) }\end{array}$ & $\begin{array}{l}\text { Alternative lifestyle community need affordable } \\
\text { and healthy food, jobs, and an outlet for local } \\
\text { produce, a community meeting place and } \\
\text { community services. Shared political, } \\
\text { environmental and collectivist values. Existing } \\
\text { food and housing cooperative networks facilitate. }\end{array}$ \\
\hline $\begin{array}{l}\text { 2.Organisational } \\
\text { Design }\end{array}$ & $\begin{array}{l}\text { Design of cooperative built around member } \\
\text { homogeneity. Members very involved in decision- } \\
\text { making, direct democracy, shared risks and } \\
\text { responsibilities. More authority established, but still } \\
\text { flexible. More defined and formal processes, } \\
\text { policies and structures will be set up to manage the } \\
\text { organisations growth. }\end{array}$ & $\begin{array}{l}1980-1989 \\
\text { Foundation }\end{array}$ & $\begin{array}{l}\text { Designed around characteristics of alternative life } \\
\text { style community. Shared communitarian and } \\
\text { environmental aims. No financial investment by } \\
\text { members, flat egalitarian structure, worker } \\
\text { cooperative within multi stakeholder cooperative. } \\
\text { Business processes and management of store set } \\
\text { up. Fast growth of cooperative and store. }\end{array}$ \\
\hline $\begin{array}{l}\text { 3.Growth,Glory } \\
\text { Heterogeneity }\end{array}$ & $\begin{array}{l}\text { Membership becomes more heterogeneous, interest } \\
\text { in business more varied. Member's interests start to } \\
\text { diverge. Shared grievances fade \& grievances } \\
\text { against cooperative surface. Special interest groups } \\
\text { emerge. Increased conflict and rising costs. Poorly } \\
\text { defined property (ownership) rights. More diffuse } \\
\text { responsibilities. }\end{array}$ & $\begin{array}{l}\text { 1990- } 1998 \\
\text { Transition }\end{array}$ & $\begin{array}{l}\text { Growth slowed and stabilised. Worker cooperative } \\
\text { modified to 2tier structure. Works well. } \\
\text { Governance issues from mid 90's. Harder to find } \\
\text { members to govern cooperative. Members } \\
\text { confused about roles and decision-making } \\
\text { processes. }\end{array}$ \\
\hline $\begin{array}{l}\text { 4.Recognition and } \\
\text { Introspection }\end{array}$ & $\begin{array}{l}\text { Issues of heterogeneity begin to arise. Members fall } \\
\text { into different 'camps' Fragmented coalitions arise, } \\
\text { cooperative purpose and direction less focused and } \\
\text { ill defined. Less willing to engage in discussion } \\
\text { because of increased conflict, collective decision } \\
\text { making becomes more costly. Members or leaders } \\
\text { eventually demand action to remedy challenges. }\end{array}$ & $\begin{array}{l}1999-2003 \\
2^{\text {nd }} \\
\text { Generation }\end{array}$ & $\begin{array}{l}\text { Membership falling, workers more diverse and } \\
\text { take less responsibility for store. Consumer } \\
\text { member influence strengthens worker influence } \\
\text { declines. First big financial loss. Worker } \\
\text { cooperative disestablished. Tinkering with } \\
\text { structure and management of store fails. }\end{array}$ \\
\hline 5. Choice & $\begin{array}{l}\text { Accelerating, self- reinforcing degenerative spiral. } \\
\text { Cooperative faces decision about survival. Based } \\
\text { on how the directors choose to "tinker, reinvent, or } \\
\text { spawn," a new life cycle may begin or exit through } \\
\text { demutualising or selling. }\end{array}$ & $\begin{array}{l}2004-2010 \\
2^{\text {nd }} \\
\text { Generation }\end{array}$ & $\begin{array}{l}\text { Committee takes management of store. Manager } \\
\text { appointed and fails. Cooperative lost community } \\
\text { support, customers. Significant population loss. } 5 \\
\text { years financial losses. Cooperation breaks down. } \\
\text { Members eventually force change. Decision to } \\
\text { reestablish worker cooperative. }\end{array}$ \\
\hline
\end{tabular}


In terms of a mechanism for sustainable development the cooperative meets many of the criteria suggested by Birchall (2003; 2006), Shaw, (2006) and FAO (1996) described in Chapter 2. It had strong local roots which reinforced local economic development and fostered sustainability through close links with the community from which its members are drawn. The cooperative provided a way for people to organise and mobilise around economic, social, cultural needs. It fostered democracy and focused on longer-term aims rather than on maximising short-term profits. It is a community-owned, governed and managed enterprise directed to meeting community identified needs.

\subsection{CONCLUSIONS}

The cooperative experienced cycles of growth, stasis and decline and showed some resilience in surviving these. The ability of the organisation to respond to challenges was predicated upon an internal capacity to do. At times internal capacity has been strong, at other times very weak. Financial data suggest the sale of petrol and location of the store in a tourist destination was pivotal to the survival of the cooperative's trading activities. ${ }^{133}$

Demographic changes in the community impacted significantly. This reduced the number of customers and pool of people with business and governance skills on whom the cooperative could draw. There is no evidence of planned succession within the cooperative to ameliorate this problem. Lack of business skills was a critical issue, suggesting in-effective leadership.

The boundary between governance and management was a long-standing source of friction and confusion for members. Divergence between the interests of consumer and worker members of the cooperative developed over time. In the first half of the organisation's history the interests were reasonably well balanced. The change to voluntary membership for workers was a turning point in the governance and financial fortunes of the organisation. This heralded a long period of decline in commitment to the cooperative's aims and objectives being expressed through the store.

\footnotetext{
133 Petrol sales account for more than a quarter of annual turnover. Summer holiday period sales account for about a third of annual turnover. CGS Annual Accounts 1979-1989, 1995 and 1997 20009.
} 
The cooperative has struggled to retain a viable trading business, even in good years. It owns a marginal rural business in which tight control of stock, costs and cash flow is critical. Sometimes that has been done well; at other times so poorly it led the business to the brink of collapse. Throughout its history the cooperative has subsidised jobs and services to its financial detriment.

Overall the organisation was often slow to respond to change and unwilling to act. The loss of cooperative spirit and group decision-making appear instrumental in the organisation's most critical business difficulties. There is good evidence however that many of its community development aims and objectives were achieved, and these sustained over long periods of time.

The cooperative's development conforms in many respects with Cook (2003) and Cook \& Burress (2009) five stages of cooperative development described in Chapter 2, but with important differences. The Cook \& Burress model emphasises economic considerations, whereas the Colville Cooperative demonstrates the importance of non-economic (social, political and philosophical) considerations. However the case expresses many characteristics of a modified Degeneration Theory of Cooperatives (Batsone, 1983; Hind, 1999; Cook, 2005; Valentinov, 2007; Cook \& Buttress, 2009).

As applied to the cooperative, these models helped to identify that cooperative degeneration is heavily influenced by local economic and social changes.

The literature emphasises the importance of cooperatives being closely aligned to needs of members, which, in the case of Colville, is also the community. Birchall \& Ketilson (2009) found that when cooperatives aren't aligned with member needs they lose interest and stop participating. This was proven in the Colville example.

The case is consistent with the findings of Birchall \& Ketilson (2009) that cooperatives are a particularly resilient form of enterprise, able to withstand crisis and protect livelihoods in hard times. This finding suggests they are well suited to community owned enterprise, where variations in the capacity of the community to sustain an enterprise will fluctuate over time as members come and go. 


\section{5. FINAL CONCLUSION}

The collapse of contemporaneous social solidarity cooperatives in New Zealand, and the maturing of social movements with which the cooperative was closely associated, leaves the Colville Cooperative as an unusual survivor of an earlier cooperative heyday (Balnave \& Patmore, 2009).

The social, economic and environmental aims and objectives of the cooperative, and its' multi-stakeholder social solidarity features, are, however, similar to new and emerging forms of cooperatives and social enterprise. The cooperative store was an early and sustained 'green' business for much of its history. Its social and community development aims and multi -stakeholder membership made it a very early expression of a successful social enterprise. These characteristics are features of modern, sustainable, green enterprises and social cooperatives, both of which represent new and profitable business models.

That fact that the Colville Cooperative is currently not flourishing, at a time when this type of enterprise is on the rise and potentially the future face of business activity in development and other sectors, is explained by the challenges of the current stage of its lifecycle at the degeneration "choice" stage. This stage will take time to resolve but some new growth is evident. As a case study of social enterprises in New Zealand, analysis of the case in this thesis provides a unique set of insights into a rural cooperative over an extended length of time. These insights are a basis for further reflection on the future of the cooperative itself, consistent with action research. The thesis also provides a comparative case for ongoing analysis of local economic development in rural New Zealand. 


\section{REFERENCES}

Autumn, J. ( 2010). Discussion on number of employees in the worker cooperative's first year. Personal communiciation [face to face] on 23 August 2010.

Avon Cooperative Development Association. (2002). Community Cooperatives. Cooperative Assistance Network Information Series. Avon. Cooperative Assistance Network. Accessed 10 March, 2010 from www.cda.coop/communitycoops.ht

Avon Cooperative Development Association. (2002). Worker Cooperatives.

Cooperative Assistance Network Information Series. Avon. Cooperative Assistance Network. Accessed 10 March, 2010 from www.cda.coop/workercoops.ht

Balnave, N., \& Patmore, G. (2009). Practical Utopians: Rochdale Consumer Cooperatives in Australia and New Zealand. Journal of Labour History. 95:111. London. Routledge

Batsone, E. (1983) Organisation and Orientation: A Life Cycle Model of French Co-operatives. Economic and Industrial Democracy 4(2): 139-161. London. Sage Publications

Beca, Carter, Hollings \& Ferner Associates (2007). Demographic Profile Statement. Framework for our Future. Hamilton. Thames Coromandel District Counicil \& Environment Waikato. Accessed August 9, 2010 from ww.tcdc.govt.nz/plans/community

Bedogni, A. (1983). Unpublished Masters of Philosophy Thesis. Rural Population Growth and Institutional Response: Thames-Coromandel District. Auckland. Auckland University. 
Bibby, A. (2005). Community investment in good food. Observer Business. 9 March, 2003:13. London. The Observer. Accessed 2 November, 2010 from www.guardianbusiness/money/ethicalmoney/corporatesresonsibility

Bibby, A., \& Shaw, L. (eds). (2005). Making A Difference. Cooperative Solutions to Global Poverty. Cooperatives at Work. Manchester. UK Department for International Development

Birchall, J. (1998). The Future of Co-operative and Mutual Business. Tokoyo. Meiji University. Accessed 21 May, 2010 at www.nz.coop/docs/johnston.html

Birchall, J. (2003). Rediscovering the Cooperative Advantage. Poverty Reduction Through Self Help. Geneva. ILO.

Birchall, J. (2006). The Role of Cooperatives in Poverty Alleviation. Paper presented at CA Regional Conference on the role of co-operatives in poverty alleviation in Asia held in March, 2006. Accessed 5 March, 2010 at www.caledonia.org.uk/papers/Role-of-Coops-in-Poverty-Alleviation.pdf

Birchall, J., \& Ketilson, L. (2009). Responses to the Global Economic Crisis. Resilience of the Cooperative Business Model in Times of Crisis. Geneva. ILO

Borzagac, C., \& Defourmey J. (2001). The Emergence of Social Enterprise. London. Routledge

Boswell, K., Brown, D., Maniapoto. J., \& Kruger, T. (1994). Grassroots 2. Community Development Initiatives At The Grassroots. Policy Technical Paper 94/10. Wellington. New Zealand Ministry of Agriculture and Fisheries.

Bradford, S. (2004) Jobs Jolt Shock. Green Party of Aotearoa. Press release January 15, 2004. Wellington. Green Party of New Zealand. Accessed 4 May , 2010 at www.greens.org.nz/features/jobs-jolt-shock 
Bryman, A. (2009). Triangulation. Loughborough. Loughborough University.

Buglione, S., \& Schlüter, R. (2010). Solidarity based and cooperative economy and ethical business. Trends, Innovations and Experiences in Europe. Brussels. Rosa Luxemburg Foundation.

Bull, C. (1999). Retaining Cooperative Characteristics Amid Globalisation. Wellington. Nuffield Foundation.

Chaddad, F., \& Cook, M. (2003). The Emergence of Non-Traditional Cooperative Structures. Paper presented at NCR-194 Research on Cooperatives Annual Meeting, held 29 October, 2003 in Kansas City, Missouri. University of Missouri. United States. Accessed 3 February, 2010 at http: ageconsearch.umn.edu/bitstream/31799/1/cp03ch13.pdf

Chaddad, F., \& Cook, M. (2004). Understanding New Cooperative Models: An Ownership-Control Rights Typology. Review of Agricultural Economics 26, no. 3: 348-360. Blackwell Publishing

Colville Historical Committee. (1990). In The Shadows of Moehau. A history of the Colville region. Wellington. Wendy Pye Ltd

Cook, B., Dodds, C., \& Mitchel, W. (2001). Social Entrepreneurship: whose responsibility is it anyway? The false premises of social entrepreneurship. Newcastle. University of Newcastle

Cook, M. (2005). Understanding and Teaching New Cooperative Structures. Columbia. University of Missouri

Cook, M., \& Burress, M. (2009). A Cooperative Life Cycle Framework. Columbia. University of Missouri . Accessed on 29 June 2010 at http:// departments.agri.huji.ac.il/economics/en/events/p-cook.pdf 
Cook, M., \& Chaddad, F. (2004). Redesigning Cooperative Boundaries: The Emergence of New Models. American Journal of Agricultural Economics: 86 (5): 1249-1253. Oxford University Press.

Cooperative Workers' Trust (1984). Nga Rongo Korero: Co-operatives and Work Trusts News, 6. Auckland. New Zealand Cooperative Worker's Trust

Cornforth, C. (2004). The Governance of Cooperatives and Mutual Associations: A Paradox Perspective. Annals of Public and Cooperative Economics 75 (1): 11-32. Wiley-Blackwell Publishing

Craig, B., \& Pencavel, J. (1992). The Behaviour of Worker Cooperatives. The Plywood Companies of the Pacific Northwest. American Economic Review. 82 (5):1083-1105. Pittsburgh. American Economic Association

Coromandel Peninsula Post ( 2010) Colville. Coromandel Peninsula Post,11 February, 2010:1-2. New Zealand. Accessed 16 March, 2010 at www.peninsularpost.co.nz/literature 478 99/11 February 2010

Crothers, C. (2008). Recent Land Use Changes in Rural New Zealand: broad statistics. Paper presented at Conflict in Paradise: the transformation of rural New Zealand EDS Conference held 11-12 June, 2008 in Auckland. New Zealand Environmental Defence Society. Accessed 6 June, 2010 at www.edsconference.com

Dairy Companies Association of NZ (2010). Dairy farming is part of a long and proud agricultural tradition in New Zealand. Dairy Companies Association of NZ website. Accessed on 4 July, 2010 at www.dcanz.com/about-nzdairyindustry

Dahal, G., \& Adhikari, K. (2008). Bridging, Linking and Bonding Social Capital in Collective Action. The Case of Kalahan Forest Reserve in the Philippines. 
CAPRi Working Paper, No. 79. United Kingdom. Accessed 15 October, 2010 www.capri.cgiar.org/pdf/capriwp79.pdf

Davis, P. (2002). Cooperative Development and Local (Rural, Urban)

Community. Towards a Bottom Up Strategy to Rebuild the Social

Foundations of Cooperating. Paper presented at Supportive Environment for Cooperatives Conference held in April, 2002 in Ulaanbaatar, Mongolia.

Leichester. University of Leicester. Accessed 17 April, 2010 from www.un.org/index/.../SupportiveEnvironment.aspx.

Dees, J. (1998). Enterprising Non-Profits. Harvard Business Review: 76 (1), 55-67. Cambridge, MA. Harvard University Press

Department for International Development (2005). How to leverage the cooperative movement for poverty reduction. Policy Division Information Bulletin: 067:1-7. London. UK Department for International Development

Dudding, V. \& Ryan, C. (1999). The impacts of tourism on a rural retail sector: a New Zealand case study. Tourism Economics 6 (4): 301-319. London. IP Publishing

Easton, B. (2009). Reliving the 70's horrors. If Nothing is Done our Credit Rating Will be Downgraded and Interst Rates Will Rise. New Zealand Listener 220 (3518). Auckland. APN Holdings Ltd

Environment Group Auckland Inc. (n.d.) Directions. A Directory To Coop's. Auckland. Community Enterprise Loans Trust

Estrin, S. \& Jones, D. (1993). The Viability of Employee-Owned Firms: Evidence from France. Industrial and Labour Relations Review. 45 (2):323339. Online journal. Ithica, NY. Cornell University. Accessed on 6 July 2010 at http://digital commons.ilr.cornell.edu/ilrreview 
European Union. ( 2003). Council Regulation (EC) No 1435/2003 of 22 July 2003. Statute for a European Cooperative Society. Brussels. European Union.

Evans, L. \& Meade, R. ( 2005). The Role and Significance of Cooperatives in New Zealand Agriculture: A comparative Institutional Analysis. Wellington. New Zealand Ministry of Agriculture and Fisheries

Evans, P, \& McCalman, J. (1982). Rural co-operatives in New Zealand: 12 case studies. Auckland. Community Enterprise Loan Trust

Farmer, P. (2008). Three Stories, Three Paradigms, and a Critique Innovations. Technology, Governance, Globalisation. Skoll World Forum Special Edition: 2008:19- 27. Cambridge MA. MIT Press

Federated Farmers of New Zealand (1982). New Zealand Cooperatives in the 1980s. J. Goulter (ed). Proceedings of seminars held in Christchurch and Auckland in April, 1981. Federated Farmers \& Lincoln College Foundation.

Fitzsimons, B. (1982). Work Cooperatives. A Manual. Occasional Paper on Community Development 1:1982. Wellington. New Zealand Department of Internal Affairs.

Fletcher, R. (1975). Workers Cooperation. Annals of Public and Cooperative Economics 47(2): 181-206. Wiley-Blackwell Publishing

Food and Agriculture Organisation (1996) Cooperatives: Has Their Time Come - or Gone? Rome. FAO.

Fox, A. (2004). Cracking Cooperatives. Unlimited. 1. Auckland. Fairfax Media. Accessed 22 July, 2010 at www.unlimited.co.nz/unlimited.nfs/growth/cracking-cooperatives 
Fox, A. (2009). The cooperative business model. Unlimited. 1-2. Auckland.

Fairfax Media. Accessed on 22 July at

www.unlimited.co.nz/unlimited.nfs/money/cooperative-business

Freundlich, F. (1998). Mondragon Cooperative Corporation. Briefing paper for

Shared Capitalism: Mapping the Research Agenda Conference held 22-23

May, 1998 in Washington, D.C. Bilbao. Ownership Associates Spain.

Accessed on 3 November 2010 at

www.clcr.org/publications/other/Intro_To_Mondragon.doc

Gibson, R. (2005). The Role of Cooperatives in Community Economic Development. RDI Working Paper No 2005-3:1-12. Brandon, Manitoba. Brandon University.

Gill, R. (1989). Inventory of Labour Market Measures 1970-1989. Department of Labour Occasional Paper 1989/3. Wellington. New Zealand Department of Labour

Girard, J. (2009.) Solidarity Cooperatives. How Social Enterprises can Combine Social and Economic Goals. OECD Journal: Employment. 2: 245291. Paris. OECD Publishing

Gray, M. (1987). Trends and Problems in Rural Social Services Delivery. Discussion Paper No. 113. Rural Economy and Society Study Group Symposium on Rural Research Needs. Chapter 5: 39-54. (ed) J. Fairweather. Christchurch. Canterbury University

Grigg, R. (1987). Changing Roles of Women. Discussion Paper 113. Rural Economy and Society Study Group Symposium on Rural Research Needs: 10: 95-104 (ed) J. Fairweather. Christchurch: Canterbury University 
Gonzales, V. (2010). A different kind of social enterprise: social cooperatives and the development of civic capital in Italy. Community Development Journal 41(1): 25. Oxford. Oxford University Press

Goodrich, D. (2007). Qualitative Research Techniques. Wellington. New Zealand Social Science Network

Hackwell, M. (2007). Unpublished Doctoral Thesis, Articulating neoliberal goals with social democratic values. Labour's coalition of special interests. Towards a Neoliberal Citizen Regime. A Post-Marxist Discourse Analysis: 5:194-227. Hamilton. University of Waikato

Hansaard (2003) New Zealand Parliamentary Debates. Journal of the House for 6 August 2003. Hansard 610: 7653. Wellington. New Zealand Parliament

Hansmann, H. (1996). The Ownership of Enterprise. Cambridge, MA. Harvard University Press.

Hazen, P. (2008). Leadership Most Cooperative. MWorld Summer: 2008:3639. Online magazine. New York. American Management Association. Accessed on 4 March 2010 at MWorld.com

Hind, A. (1997). The Changing Values of the Cooperative and its Business Focus. American Journal of Agricultural Economics. 79: 4: 1077-1082. Oxford. Oxford University Press

Hind, A. (1999). Co-operative Life Cycles and Goals. Journal of Agricultural Economics 50: 3: 536-548. Blackwell Publishing

Hind, A. (1999). Cooperative Performance - is there a dilemma? Journal of Cooperatives.14 1999: 30-43. Kansas State University. Accessed on 7 August 2010 at http:// ageconsearch.umn.edu 
International Cooperative Alliance (2005). World Declaration on Workers Cooperatives. ICA General Assembly held on 23 September, 2005 in Brussels. Geneva. IAC. Accessed 30 June, 2010 at www.cicopa.coop/IMG/.../Declaration_approved_by_ICA_EN-2.pd

International Cooperative Alliance (2007). International Cooperative Alliance Statutes. Article 6:1. Principles. ICA Extraordinary General Assembly held on 5-6 June , 2007 in Rome. Geneva. IAC. Accessed 30 June, 2010 at www. onlinelibrary.wiley.com/d doi/10.1111/j.1467-8292.1966.tb00159.x/pdwww.ica

International Labour Organisation (2001) Promotion of cooperatives: job creation in small and medium sized enterprises. Report V (1) $89^{\text {th }}$ Session of International Labour Conference. Geneva. ILO. Accessed on 20 November, 2009 at http://nz.coop/docs/int_labour_conference.php

International Labour Organisation (2002). Promotion of Cooperatives Recommendation. General Assembly Session 90: R193. Geneva. ILO. Accessed on 20 October, 2009 at www.ilo.org/ililex/cgi-lex/convde.pl?R193

International Labour Organisation. (2008). How do Cooperatives Contribute to Local Economic Development? Cooperative News. 3: 2008. Geneva. ILO

Jeffs, L. (2006). Social Entrepreneurs and Social Enterprises. Do They Have a Future in New Zealand? Paper presented at 51st ICSB World Conference held 18th-21 June, 2006 in Melbourne, Australia. Accessed 20 April, 2010 from www.communityresearch.org.nz/wp-content/uploads/tdomf/...jeffs3.pdf

The Jobs Letter (2003) Jobs Jolt. The Jobs Letter: 190:1-6. New Plymouth. Jobs Research Trust

Jones, T \& Baker, lan. (1975). A Hard-Won Freedom. alternative communities in New Zealand. Auckland. Hodder \& Stoughton 
Kelsey, J. (1993). Rolling Back the State: The Privatisation of Power in Aotearoa New Zealand. Wellington. Bridget Williams Books Ltd

Kelsey, J (1999). Without Our Consent? Reclaiming the Future. New Zealand and the Global Economy. Wellington. Bridget Williams Books Ltd

Kerr. R. (1999.) Cooperatives versus Corporates. Paper presented at $10^{\text {th }}$ Food and Agribusiness Congress held 30 November - 2 December 1999 at University of Otago, Dunedin. Accessed 29 February, 2010 www.nzbr.org.nz/shop/.../Cooperatives+Versus+Corporates.html

Knowles, S. (2005). The Future of Social Capital in Development Economics. Paper presented at Thinking Ahead. The Future of Development Economics. WIDER Jubilee Conference held 17-18 June, 2005 in Helsinki. Accessed 13 February, 2011 at www.business.otago.ac.nz/econ/Personal/SK/soccap_05.pdf

Kristensen, K. (2009). Waikato Regional Land Transport Strategy Review. Access and Mobility and Public Health Outcome areas: Outcome statements and challenges. Hamilton. Waikato District Health Board

Len, A., Keenoy, T., Smith, R., Scott Cato, M., Anthony, P. (April, 2004). Cooperative production - a contentious social space? Paper presented at 22nd Annual International Labour Process Conference held 5-7 April, 2004 in Amsterdam. London. UWIC Cardiff \& Kings College London. Accessed 18 May, 2010 at www.uwic.ac.uk/ubs/research/wirc/publications

Lochner, M. \& Botes, L. (2007). Income generation, local economic development and community development: paying the price for lacking business skills? Community Development Journal 42 (3): 379- 395. Oxford. Oxford University Press 
Logue, J. \& Yates, J. (2005). Productivity in cooperatives and worker-owned enterprises: Ownership and participation make a difference. Geneva. ILO

Mackay, M., Perkins. H., \& Espiner, S. (2009). The Social Science of Rural Change. The Study of Rural Change from a Social Scientific Perspective. A Literature Review and Annotated Bibliography. Lincoln. Lincoln University

Margolis, R ( 2010) Discussion of ownership of New Zealand cooperatives and why cooperatives fail [phone conversation] (Personal communication on 9 June 2010)

Margolis R ( 2011). Discussion on veracity of information on current MED Register of Industrial and Provident Society's [phone conversation] (Personal communication, on 5 February 2011)

Margolis, R ( 2011). Discussion of registered cooperative organisations which do not operate as cooperatives [phone conversation] (Personal communication on 7 July 2011)

Mansuri, G., \& Vijayendra R. (2003). Evaluating Community-Based and Community-Driven Development: A Critical Review of the Evidence. New York. World Bank

Mc Gowan, T (2007) A Conversation with Organic Valley CEO George Siemon. Cooperative Business Journal Jan/Feb: 2007:6. Washington DC. National Cooperative Business Association

Melgarejo, Z., Simon, K., \& Arcelus, F. (2010). Differences in Financial Performance Amongst Spanish SME's According To Their Capital-Ownership Structure: A Descriptive Analysis. Annals of Public and Cooperative Economics 81 (1):105-129. Wiley-Blackwell Publishing 
Mendell, M \& Nogales, R. (2009). The Changing Boundaries of Social Enterprises. Social Enterprises in OECD Member Countries: What are the Financial Streams? (ed) A. Noya. Paris. OECD Publishing.

Mercer, J. (2007). The Challenges of Insider Research in Educational Institutions: Wielding a double-edged sword and resolving delicate dilemmas. Oxford Review of Education 33 (1)1-17. Oxford. Taylor and Francis. Accessed on 17 April 2010 at http://www.informaworld.com/smpp/content $\sim \mathrm{db}=\mathrm{all}$ ?content=10.1080/030549 80601094651 Doi: 10.1080/03054980601094651

Ministerial Task Force on Social Welfare Services (1986). Wellington. New Zealand Department of Social Welfare

Ministry of Agriculture \& Forestry (1994). Aspects of New Zealand's Experience in Agricultural Reform since 1984. MAF Policy Technical Paper 94/5. Wellington. New Zealand Ministry of Agriculture \& Forestry

Ministry of Economic Development (2010) New Zealand Registry of Industrial and Provident Societies. Wellington: New Zealand Companies Office. Accessed 30 March, 2010 at www.med.govt.nz.

Ministry of Economic Development (2009). Cooperative Organisations.

Establishing a Cooperative Company or Industrial and Provident Society. New Zealand Companies Office. Accessed 30 March, 2010 at www.companies.govt.nz.

Morrison, P. \& Waldegrave, C. (2002). Welfare reform and the intra-regional migration of beneficiaries in New Zealand. Geoforum. 33:1:33: 2002. 85-103. Elsevier. United Kingdom

Mountjoy, L. (2010) Discussion about Colville Cooperative membership data [phone conversation]. (Personal communication on 22 August, 2010). 
Navarro, V. (2004). Is capital the problem or the solution? International Journal of Epidemiology. 33:2004: 672-674. Oxford: Oxford University Press New Zealand Cooperatives Association (2010). Membership Information. Webpage. Accessed 1 March, 2010 at www.coop.org

New Zealand Cooperatives Association (2010). Types of Cooperative. Webpage. Accessed on 3 March, 2010 at www.coop.org.nz

New Zealand Cooperatives Association (2010). Understanding Coops. Webpage. Accessed on 3 March, 2010 at www.coop.org

New Zealand Government (2000) ILO Promotion of Cooperatives Report v (1) - questionnaire. Response by the New Zealand Government to the ILO on Behalf of the Tripartite Representatives. New Zealand Ministry of Economic Development. Accessed on 20/11/2009 at http://nz.coop/docs/010529_nzgovt_response_to_ilo_on_coops.php

New Zealand Information Network (2009) Coromandel Peninsula: Colville. Webpage. Online tourist information resource. Accessed 2 December, 2009 at www.newzealandnz.co.nz

Peattie, K. \& Morley, A. (2008). Social Enterprise. Diversity and Dynamics, Context and Contributions. Social Enterprise Coalition/ESRC Research Monongraph. Cardiff:. Wales Economic \& Social Research Council. Accessed on 5 February, 2011 at www.brass.cf.ac.uk .

Plunkett Foundation (2010). Julie Walters Opens Land Mark CommunityOwned Shop. Plunkett Foundation Weekly News. 4 June: 7: 2010. Woodstock, Oxfordhsire. Plunkett Foundation. Accessd on 24 September 2010 at www.plunkett.co.uk/whatwedo/rcs/ruralcommunityshops.cfm 
Pomeroy, A., Burborough, T., \& Cumberworth, S.(1998). Gender Equal. A Sustainable Agriculture Facilitation Programme. Wellington. New Zealand Ministry of Agriculture and Forestry

Poole, W. (1969). Co-operative Retailing in New Zealand. Research Paper No 13:1:1969. Wellington. New Zealand Institute of Economic Research.

Putnam, R \& Feldstein, L (2003). Better Together. Restoring the American Community. Simon \& Schuster

Rabbitt, E. (2003). Insider research: The implications of conducting research in your home locale. Referred paper RAB 03740 Perth. Edith Cowan University

Rae, A. Nixon, C. \& Lattimore, R. (2003). Adjustment to Agricultural Policy Reform - Issues and Lessons from the New Zealand Experience. Wellington: Massey University \& New Zealand Institute of Economic Research

Robb, A. (2008). Mutuality in the Global Financial Crisis. Paper prepared for the International Cooperative and Mutual Insurance Federation meeting held 27 November 2008 in Christchurch, New Zealand. Accessed on 13 August, 2010 at $w w w$.alanrobb.coop/?cat $=3 \&$ paged $=2$

Robb, A. (2009). Three secrets of success in New Zealand Coop's. Robb on Cooperation. Blog . Posted 29 October, 2009 on NZ Cooperatives Association website. New Zealand. Accessed on 21 April, 2010 at ww.nzcoop.org.nz

Robertson, N., Perkins, H., \& Taylor, N. (2007). Multiple job holding: Interpreting Labour Market Change and Economic Diversification in Rural Communities. Paper presented at Institute of Australian Geographers Conference held 1-6 July 2007, Melbourne, Australia. Christchurch. Taylor, Baines \& Associates. Online paper accessed 17 November, 2010 at www.tba.co.nz 
Roopali, J., de Boer, M., Pusch, H., Sankar, R. \& Wong, K. (2004). Evidence to date on the working and effectiveness of alternative labour market programmes in New Zealand. Wellington. New Zealand Ministry of Social Development

Saunders, G. (2009). A new funding paradigm. Prospects for social lending and investment by foundations in New Zealand. Auckland. ASB Community Trust \& Tindall Foundation

Schuller, T., Brown, S., \& Field, T. (2000). Social Capital. A Review and Critique. Oxford University Press

Scotts, M., McNab, J., \& Tao, C. (1987). Voices of the Land: building community. Social needs assessment of northern Coromandel Peninsula. Thames. Colville Action Group

Sen, A. (1966). The Labour Allocation in a Cooperative Enterprise. Review of Economic Studies: 33:4 (October 1966): 361-371. Oxford. Oxford University Press

Shaw, L. (2006). Over view of Corporate Governance Issues for Cooperatives. Briefing paper for Global Corporate Governance Forum Working Meeting on Corporate Governance and Co-operatives held 8 February 2007 in London. Manchester. The Cooperative College. Accessed on 18 January, 2010 at www.ifc.org/ProceedingsCooperativeDiscussionPaper/GCGF_Discussion_Pa per_Corporate_Governance_Issues_for_Cooperatives_070108p

Shaw, L (2009) Cooperatives and International Development. Cooperatives for Development. Briefing Paper 2. London. UK Department for International Development. 
Smith, G. (2002.) Community Research: A Practitioners Perspective on Methods and Values. Journal of Community Work and Development [Online]. 1 (3): 31-48.. Oxford Journals. Accessed on 24 March, 2010 at uel.ac.uk/G. Smith/gpubs.html.

Smith, B., and Herbert, J. (1997) Community-based Initiatives: Gateways to Opportunities. Report of the Community-based Action Research Project.

Canberra. Australian Department of Social Security

Spear, R. (2000). The Cooperative Advantage. Annals of Public and Cooperative Economies :72 (4):2000. 507-523. Blackwell Publishing

Stansfield, J. (2010). Social enterprise. Let down your hair. New Dialogue: 30:1: 2010. Wellington. New Zealand Federation of Voluntary Welfare Organisations

Statistics New Zealand (2008). Thames Coromandel Quarterly Review. March 2008. Wellington. Statistics New Zealand

Stockwell, D. ( 2009). The Impact of Big Box Retailing on the Future of Rural SME Retail Businesses: A Case Study of the South Taranaki District. Unpublished Masters Thesis. Auckland. Auckland University of Technology

Taylor, N., Bryan, H \& Goodrich, C. (1990). Social Assessment - theory, process \& techniques. Studies in Resource Management:7:1990. Lincoln Lincoln University.

Taylor, N., Fitzgerald, G., Robertson, N., McClintock, W. (2007). Labour Market Changes and Social Capital: Some Issues for Social Policy. Paper presented at Investing in Social Success" Social Policy Research and Evaluation (SPRE) Conference held 3-5 April, 2007 in Wellington. Christchurch. Taylor Baines and Associates 
Teaham, B. (2006). Community Enterprises: enduring institutions for a newer world. Unpublished Doctoral Thesis. Wellington. Victoria University of Wellington

Thames Coromandel District Council (2006). Coromandel Peninsula Blueprint Economy Profile Statement. Thames. Thames Coromandel District Council

Thames-Coromandel District Council (2008). Peak Population Report 2007/2008. Thames. Thames Coromandel District Council.

Thames-Coromandel District Council (2008).Long Term Community Plan 2008-2019. Thames. Thames Coromandel District Council

Troberg, E. (2009). Implications of Value-driven Entrepreneurship in Finnish Employee-owned Cooperatives. Journal of Cooperative Studies: 42 (3):36-45. Liverpool. UK Society for Co-operative Studies

Tyne, C ( 2010). Population statistics for TCDC area since 1990. [Email] (Personal communication on 28 October, 2010).

United Nations Economic and Social Council (1996) Status and role of cooperatives in the light of new economic and social trends. Report to the Secretary General A/51/150, 6 August, 1996 for the $51^{\text {st }}$ Session of the UN General Assembly, Item 102. New York. UN

United Nations (2001). Cooperatives in Social Development. Report of the Secretary General No A/56/73 E/2001/68 for the $56^{\text {th }}$ Session of the UN General Assembly, Item 121. New York. UN

Valentinov, V. (2007). Why are cooperatives important in agriculture? Journal of Institutional Economics. 2007:3 (1): 55- 69. Cambridge University Press

Whitman, J. ( 2011).The Worker Cooperative Lifecycle. A paper prepared for the Babson-Equal Exchange Cooperative Curriculum. Wellesley, MA . Babson 
College. Accessed on 21 January, 2011 at cooperativeurriculum. wikispaces.com/The+Worker+Cooperative+Life+Cycle-Whitman.pdf

Williams, I. (1997). Choral Societies and Export Growth. Social Capital and Policy Development (ed.) D. Robinson. Wellington. New Zealand Institute of Policy Studies

Williamson, K (2000). Research methods for students and professional. Australasian Library and Information Studies. Perth. Charles Sturt University

Woodford. K. (2003) New Generation Cooperatives and Related Business Structures. Paper presented at Cooperative Directors Seminar held in Wellington, September 2003. Wellington. New Zealand Cooperatives Association

World Bank (1993). Review of Cooperatives and Other Rural Organisations in Ghana. Rome. World Bank

Zeuli, K. (2002). The Role of Cooperatives in Community Development. Centre for Cooperatives Bulletin 3:2002: 1-4. Madison. University of Wisconsin. Accessed 23 September 2010 at www. uwcc.wisc.edu/pdf/Bulletins/bulletin_09_02 pdf

Zeuli, K., Freshwater, D., Markley, D., \& Barkley, D. (2004). Cooperatives in Rural Community Development: A New Framework for Analysis. Journal of the Community Development Society. 35 (2 ): 2004:17-36. Oxford University Press 